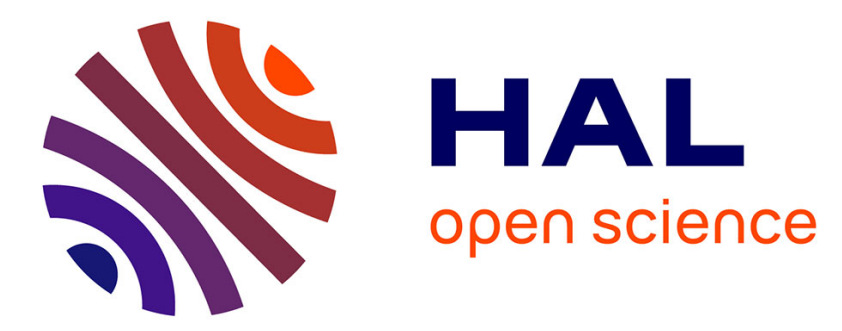

\title{
Controls of magma chamber zonation on eruption dynamics and deposits stratigraphy: The case of El Palomar fallout succession (Tenerife, Canary Islands)
} Joan Martí, Silvia Zafrilla, Joan Andújar, María Jiménez-Mejías, Bruno Scaillet, Dario Pedrazzi, Domenico Doronzo, Stéphane Scaillet

\section{To cite this version:}

Joan Martí, Silvia Zafrilla, Joan Andújar, María Jiménez-Mejías, Bruno Scaillet, et al.. Controls of magma chamber zonation on eruption dynamics and deposits stratigraphy: The case of El Palomar fallout succession (Tenerife, Canary Islands). Journal of Volcanology and Geothermal Research, 2020, 399, pp.106908. 10.1016/j.jvolgeores.2020.106908 . insu-02569124

HAL Id: insu-02569124

https://hal-insu.archives-ouvertes.fr/insu-02569124

Submitted on 11 May 2020

HAL is a multi-disciplinary open access archive for the deposit and dissemination of scientific research documents, whether they are published or not. The documents may come from teaching and research institutions in France or abroad, or from public or private research centers.
L'archive ouverte pluridisciplinaire HAL, est destinée au dépôt et à la diffusion de documents scientifiques de niveau recherche, publiés ou non, émanant des établissements d'enseignement et de recherche français ou étrangers, des laboratoires publics ou privés. 


\section{Journal Pre-proof}

Controls of magma chamber zonation on eruption dynamics and deposits stratigraphy: The case of El Palomar fallout succession (Tenerife, Canary Islands)

Joan Martí, Silvia Zafrilla, Joan Andújar, María Jiménez-Mejías, Bruno Scaillet, Dario Pedrazzi, Domenico Doronzo, Stephane

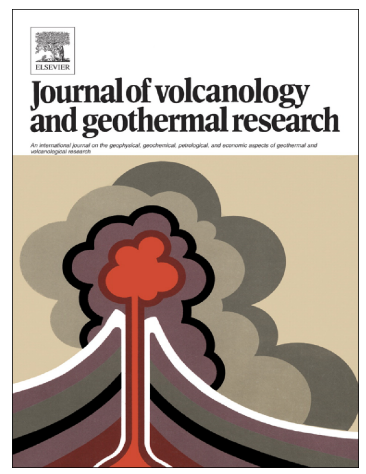
Scaillet

PII: $\quad$ S0377-0273(20)30103-7

DOI: $\quad$ https://doi.org/10.1016/j.jvolgeores.2020.106908

Reference: $\quad$ VOLGEO 106908

To appear in: Journal of Volcanology and Geothermal Research

Received date: $\quad 17$ February 2020

Revised date: $\quad 3$ April 2020

Accepted date: $\quad 1$ May 2020

Please cite this article as: J. Martí, S. Zafrilla, J. Andújar, et al., Controls of magma chamber zonation on eruption dynamics and deposits stratigraphy: The case of El Palomar fallout succession (Tenerife, Canary Islands), Journal of Volcanology and Geothermal Research (2018), https://doi.org/10.1016/j.jvolgeores.2020.106908

This is a PDF file of an article that has undergone enhancements after acceptance, such as the addition of a cover page and metadata, and formatting for readability, but it is not yet the definitive version of record. This version will undergo additional copyediting, typesetting and review before it is published in its final form, but we are providing this version to give early visibility of the article. Please note that, during the production process, errors may be discovered which could affect the content, and all legal disclaimers that apply to the journal pertain.

C) 2018 Published by Elsevier. 


\title{
Controls of magma chamber zonation on eruption dynamics and deposits stratigraphy: The case of El Palomar fallout succession (Tenerife, Canary Islands)
}

Joan Martí ${ }^{1}$, Silvia Zafrilla ${ }^{1}$, Joan Andújar ${ }^{2}$, María Jiménez-Mejías ${ }^{1,2}$, Bruno Scaillet ${ }^{2}$, Dario Pedrazzi $^{1}$, Domenico Doronzo ${ }^{1}$, Stephane Scaillet ${ }^{2}$,

1.- Institute of Earth Sciences Jaume Almera, CSIC, Geohazards, Barcelona, Spain

2.- ISTO-CNRS, Orleans, France

3.- Centro Geofísico de Canarias, IGN, Tenerife, Spain

Corresponding author: Joan Martí (joan.marti@ictja.csic.es)

\section{Submitted to: JVGR}

\begin{abstract}
Anticipating volcanic eruptions at central volcanoes require knowing how magma chambers prepare for new eruptions. Pre-eruptive processes that occur in such magma chambers are recorded in the products of these eruptions, so their characterisation in terms of magma composition and physics offers the clues to understand past eruptions and predict future ones. Here, we study the very well preserved pyroclastic succession of El Palomar Member (712 $\pm 41 \mathrm{ka})$, in Las Cañadas caldera, Teide, Canary Islands. This deposit resulted from a single explosive eruption of a phonolitic magma that started with a sustained eruption column (sub-plinian or plinian) that formed a massive, $40 \mathrm{~m}$ thick non-welded fallout deposit, progressively changing into a lower intensity fire fountain that deposited a $25 \mathrm{~m}$ thick fallout succession of non-welded to strongly welded pumices. Stratigraphic and petrological data suggest that this eruption was related to a thermally-compositionally zoned and relatively shallow magma chamber in which the arrival of a hotter and more mafic magma rapidly triggered the eruption. The studied deposit shows how this zoned structure was maintained during the whole process, which allows to reconstruct what happened during the eruption.
\end{abstract}


Comparison of this eruption with the current situation at Teide volcano alerts on the potential rapid preparation for new eruptions in the case that sufficient phonolitic magma was available in the shallow plumbing system of this active volcano if new inputs of deeper magma take place.

Keywords: El Palomar pumice fall, Las Cañadas Edifice, Tenerife, eruption dynamics, magma chamber zonation, Teide.

\section{Introduction}

A good knowledge of the formation and dynamics of magma chambers is crucial to understanding how magmas evolve and how they subsequently erupt at the Earth's surface. The dynamics of magma chambers prior to and during volcanic eruptions has been widely studied through experimental and theoretical models (e.g., Spera, 1984; Sparks and Huppert, 1984; Sparks et al., 1984; Turner and Campbell, 1984; Huppert et al., 1984; Spera et al., 1986; Blake, 1981a, b; Blake and Ivey, 1986a, 1986b; Oldenburg et al., 1989; Rice, 1993; Trial et al., 1992; Tait et al., 1988; Bower and Woods, 1998; Folch et al., 1998, 2001; Mourtada-Bonnefoi et al., 1999; Bea, 2010; Dufek et al., 2013, among many others), which have investigated how a magma chamber structures itself chemically and physically and how this structure may remain unchanged or can be partially or totally perturbed during an eruption.

Chamber zonation models have been fuelled by field observations (e.g., Hildreth 1979, 1981; Cioni et al., 1992; Wallace et al., 1999; Coombs et al., 2000; Bryan et al., 2000; Hildreth and Fierstein, 2012; Marcaida et al., 2014; Weidendorfer et al., 2014) showing that pre-eruptive, broadly continuous zoning is indeed a common characteristic of eruption products of many small to intermediate volume eruptions (e.g., Cioni et al., 1992; Bryan et al., 2000), but is also present in some of the largest caldera-forming eruptions (e.g., Wolff and Ramos 2003; Hildreth and Wilson 2007; Wilson, 2008). However, some other deposits show different compositional patterns including abrupt gaps in composition between the erupted products (e.g., Bacon and Druitt 1988), or lack of any compositional gradients (Lindsay et al., 2001; Bachmann et al., 2002), thus suggesting that either there was no zonation in the pre-eruptive magma chamber or that processes 
such as mixing or convection occurred prior to, or during, the eruption, disturbing any existing zonation. Deciphering these processes, which may occur prior to the eruption and during it, from the erupted products is important to understand eruption dynamics and how magmas prepare to erupt. Equally important is to distinguish the processes that occur in the magma chamber from those that may occur in the eruptive conduit and that may overprint the first ones (e.g., Freundt and Tait, 1986; Koyaguchi, 1987)

In this work we focus on the Las Cañadas caldera, in Tenerife, which was generated by several caldera-forming eruptions of phonolitic magmas (Martí et al., 1994; Martí and Gudmundsson, 2000; Martí, 2019). The caldera wall exhibits an impressively continuous outcrop of the proximal facies of the products derived from the pre-caldera phonolitic centres. The distal facies of these deposits can be observed on the lower slopes of Tenerife (Martí et al., 1994; Bryan et al., 1998; Edgar et al., 2002, 2007, 2017; Brown et al., 2003), mainly close to the coast.

Here, we study the El Palomar Member, which corresponds to a continuous, $60 \mathrm{~m}$ thick, proximal pumice deposit that crops out in a vertical section at the central sector of the Las Cañadas caldera wall. This fallout pyroclastic succession is characterised by a gradual upwards transition in the degree of welding, changing from non-welded to a strongly welded deposit. El Palomar Member was studied by Soriano et al. $(2002,2006)$, in the framework of a more general approach to the welding processes for near vent facies in the Las Cañadas caldera, and by Zafrilla (2001) who described the petrology and geochemistry of the rock successions exposed along the caldera wall. The results from these previous studies revealed that the El Palomar Member presents an upwards variation in composition and physical parameters of the pumice fragments, which suggests a physical and chemical zonation of its associated magma chamber. Within this context, the main aim of this study is to report on this exceptionally well-preserved and exposed pumice deposit that may shed light on pre and syn-eruptive processes associated with phonolitic explosive eruptions from Las Cañadas and by comparison with the Pico-Viejo and Teide active volcanic complex. 


\section{Geological setting}

Tenerife is the largest island of the Canaries archipelago, which is located off the northwest margin of Africa (Fig. 1). A long period of subaerial fissure-fed mafic volcanism (ca. 12 to > $3 \mathrm{Ma}$; Ancochea et al., 1990) formed a basaltic shield structure (Old Basaltic Series; Fuster et al., 1968). Toward the end of this period, volcanic activity was concentrated in the central part of Tenerife, where shallow magma chambers developed and where the Las Cañadas central volcanic complex was constructed (Araña, 1971; Ancochea et al., 1990; Martí et al., 1994a). The Las Cañadas caldera developed at the summit of the Las Cañadas edifice (Fig. 1). It is a multicycle overlapping caldera that consists of at least three successive vertical collapse episodes, each of which occurred at the end of a long-lived phonolitic volcanic cycle that was characterised by explosive eruptions that, in some cases, emitted a few tens of cubic kilometres of products (Martí et al. 1994; Martí and Gudmundsson, 2000; Martí, 2019). The caldera depression is now partially infilled by the products of the active Teide-Pico Viejo volcanic complex, which has a summit elevation of 3,718 m; lavas from the complex were also emplaced along the northern slopes of the island (Fig. 1).

The Las Cañadas edifice is a large composite stratovolcano consisting of a dominantly mafic to intermediate Lower Group $(>3.5-<2 \mathrm{Ma})$, and a mostly phonolitic Upper Group (1.6 - 0.18 Ma). Pyroclastic rocks of phonolitic composition, including thick units of welded pyroclastic rocks that grade laterally into non-welded deposits, dominate the Upper Group and the top of the Lower Group (Martí et al, 1994; Soriano et al., 2002). The Upper Group comprises the Ucanca, Guajara, and Diego Hernández formations, each one corresponding to a distinct basaltic to phonolitic cycle that terminated with a caldera-forming episode (Martí et al., 1994; Martí and Gudmundsson, 2000; Martí, 2019). Phonolitic rocks of the Ucanca formation unconformably overlie the Lower Group and range in age from 1.57 to $1.07 \mathrm{Ma}$, while those of the Guajara formation were emplaced between 0.85 and 0.57 Ma. The phonolitic pyroclastic rocks of the Diego Hernández formation range in age from 0.37 to $0.18 \mathrm{Ma}$. The Upper Group forms the upper part of the caldera wall (Fig. 2) and most of its deposits dip down the slope of the Las Cañadas edifice and are truncated by the 
caldera wall. However, some deposits at the top of the Las Cañadas edifice dip towards the depression's interior, mantling the caldera wall (Soriano et al., 2006).

The El Palomar Member, with an age of $712 \pm 41$ ka (Martí et al., 1994), belongs to the Guajara Formation and forms an impressive cliff at the top of the caldera wall in the center of the caldera depression (Figs. 2 and 3). It is formed by a $60 \mathrm{~m}$ thick continuous pyroclastic pumice deposit that grades from base to top from non-welded to rheomorphic lava-like rocks. Its stratigraphic correlation with other sectors of the island and along the caldera wall itself has not been clearly established, but it might correspond to one of the undifferentiated pumice layers identified at the base of the Guajara Formation lying at the south of Tenerife (Bryan et al., 1998; Brown et al., 2003). The lack of stratigraphic correlation of the El Palomar Member with other sectors of the island precludes any firm estimate of the physical parameters (e.g., volume, column height, mass eruption rate) of the eruption responsible for its deposition. However, a simple comparison of the field characteristics of the El Palomar Member with other proximal deposits of Tenerife places it between a suplinian (e.g., Montaña Blanca, Ablay et al., 1995) and a plinian (e.g, Granadilla, Bryan et al., 1998) size eruption.

\section{Methods}

Field work concentrated on one single outcrop where the full succession from El Palomar Member is exposed. A detailed stratigraphic log of the succession was established by collecting a sample every $\sim 3 \mathrm{~m}$ from base to top (17 samples in total) (Fig. 3) for grain-size and petrological and geochemical analyses.

Grain-size analyses consisting of dry-sieving techniques were performed on 12 representative samples of the non-welded part of the El Palomar Member (Table 1). Large pumice fragments were not considered for sieving but were measured and considered as part of the stratigraphic column for comparison with other layers. Samples were sieved with a set of sieves with a full phi mesh size ranging from $-6 \varphi$ to $+5 \varphi$ units (64 to $0.032 \mathrm{~mm}$ ). Grain-size data were 
used to define the median diameter $(\mathrm{Md} \varphi)$ and sorting $(\sigma \varphi)$ (Inman, 1952). In the welded zones the apparent maximum elongation axis of pumices was directly measured in the field. Bulk density and porosity data on both pumice and welded deposits obtained by Soriano et al. (2002) using standard techniques and $\mathrm{Hg}$ microporosimeter, respectively, were also considered.

Fresh pumice and obsidian fragments were selected for whole-rock and mineralogical analyses. Mineral analyses were performed with a JEOL JX-8600 Electron Microprobe, at the University of Bristol, U.K., and on a Cameca SX-50 Electron Microprobe at the "Serveis Científicotècnics", University of Barcelona. We used wavelength-dispersive methods, with an accelerating voltage of $15 \mathrm{kV}$, a beam diameter of $2-5 \mu \mathrm{m}$ and a beam current of $15 \mathrm{nA}$. Analytical data were reduced automatically using the ZAF method. Data output from the microprobes were in the form of oxide and element weight percentages. Mineral formulae were initially calculated on the basis of a fixed number of oxygen atoms.

Sixteen whole rock samples were analysed for major and trace elements by X-Ray Fluorescence (XRF) at Leicester University (U.K.). All major and trace element data were normalised to $100 \%$ on an anhydrous basis before plotting. The VG PlasmaQuad Inductively Coupled Plasma-Mass Spectrometer (ICP-Ms) at Bristol University was used to determine the rareearth concentration of the samples.

As a complementary goal this study has also been used to test the suitability of a portable Xray spectrometer as a field tool to be applied to the first order characterisation of volcanic deposits, in particular whenever zoning/mixing is suspected/visible across the deposit. This not only provides guidance for rock sampling for further in-depth laboratory characterisations, but also general and rapid assistance to establish stratigraphic correlations and to unravel whether or not mechanisms such as magma mixing are present at the outcrop scale. At each location, a minimum of 3 analyses, and up to 6 , were performed, showing in the vast majority of cases homogeneous compositions for the same analysed zone. Whenever possible single pumices clasts were analysed, after having cleaned and gently crushed/flattened the analysed surface with the hammer so as to have a flat area 
3-4 times larger than the analysed portion by the apparatus (diameter of analysis of the X-ray gun is

$1 \mathrm{~cm})$. When the pumices were too small, several grains collected at the same horizon were gently crushed down and the resulting powder was analysed. Each analysed location corresponds to the same stratigraphic level $( \pm 10 \mathrm{~cm}$ of height difference), and pumices were collected to within $30 \mathrm{~cm}$ of each other in the horizontal direction. Daily tests were performed on internal standards of known major and trace element compositions (phonolitic and tephriphonolitic, and basaltic compositions, either glassy or fine-grained) showing that no apparatus drift occurred during the field campaign. Different times of data acquisition were also tested, showing that measured concentrations of elements (see below for elements considered to be faithfully analysed) did not change further after $40 \mathrm{~s}$ of analysis, and this time of data acquisition was used in this study.

\section{Field characteristics of the El Palomar member}

The studied outcrop consists of two pyroclastic deposits or units that show a cumulative thickness of about $80 \mathrm{~m}$, laterally conserving their thickness at least at the scale of the outcrop (Fig. 3). The lower deposit correspond to a finely-stratified, lithic-rich pyroclastic and partially reworked deposits (U1). The upper deposit (U2), the El Palomar Member, has a total approximate thickness of $60 \mathrm{~m}$ and corresponds to a grain-supported, pumice-rich deposit that can be divided into three zones, from bottom to top: a pumice-rich massive lower zone (Z1), a vitrified moderately to strongly welded intermediate zone (Z2), and devitrified rheomorphic lava-like upper zone (Z3) capping the pyroclastic succession (Figs 3 and 4). The contact between U1 and U2 is erosive, while the transition between $\mathrm{Z} 1$ and $\mathrm{Z} 2$ is gradual, i.e., the degree of welding increases upward, while the transition between Z2 and Z3 is sharper, but still gradual. U1 has an exposed thickness of about 20 $\mathrm{m}$ but its base is not visible (Figs. 3 and 4a). An inaccessible ravine that is visible down dip from the main outcrop suggests a much larger thickness for U1, however. U1 contains repetitive sets of dark coloured, lithic-rich versus light coloured lithic-poor (pumice rich) fine layers. Each layer is on average a few centimetres thick. The lithic fragments are of a few millimetres to a few 
centimetres in diameter, while the juvenile fragments are of a few centimetres across. At a smaller scale, it is observed that there is an upward increase in the content of lithic fragments in each set, which marks a first order alternation in U1. Its top is eroded, with numerous small size channels and reworking of the pyroclastic material just below this erosion surface (Fig. 4a).

The lower zone (Z1) of U2 (El Palomar Member) covers the U1 paleosurface and has a total thickness of $40 \mathrm{~m}$. It is a massive, grain supported, pumice deposit, composed of angular pumice fragments of several centimetres to a few decimetres in size, immersed in more abundant pumices of a few centimetres in diameter. The largest pumice fragments show a reverse grading throughout Z1. Lithic fragments up to a few centimetres in diameter are scarce, while minor grey pumice fragments with borders of obsidian up to a few decimetres across can be recognised throughout the whole $\mathrm{Z} 1$ part of El Palomar deposit. The lowermost portion of $\mathrm{Z} 1 \quad(<1.5 \mathrm{~m})$ is poorly sorted and comprises dense, poorly-vesicular pumice blocks, $25-30 \mathrm{~cm}$ in diameter, with dense, poorly-vesicular pumice fragments $(2-6 \mathrm{~cm})$. Rare lithic fragments $(<10 \mathrm{~cm})$ include phonolitic lava and/or welded rock fragments, basaltic lava and obsidian fragments. Toward the top of $\mathrm{Z1}$, welding of the pumices, marked by the collapse of the vesicles in some pumices and the obsidian-like aspect of their inter-porous walls, starts to appear (Fig. 4b), progressively increasing upward (Fig. 4c) and grading into Z2. In this transition towards Z2, three different kinds of pumice fragments occur: i) white pumices; ii) brown pumices, and; iii) streaky white and brown pumices (Fig. $4 b$ and $4 c)$.

Z2 and Z3 have an exposed thickness of 8 and 12 meters, respectively. The main macroscopic difference between zones $\mathrm{Z} 2$ and $\mathrm{Z} 3$ of the El Palomar deposit is the vitrification versus devitrification of the pumices, which gives their black versus white color (Fig. 4d), respectively. Z2 corresponds to a moderately welded pumice deposit, showing a rapid upward increase in the stretching of pumices and degree of welding. It is mostly formed by dense, nonvesicular, slightly sintered, brown pumice fragments $(10-15 \mathrm{~cm})$. The brown pumice fragments are increasingly flattened upwards, but the clast-supported fabric is also visible throughout this part of 
the deposit. Lithic fragments are scarce to absent. The contact between $\mathrm{Z} 2$ and $\mathrm{Z} 3$ is sharper (Fig. 4d). , but still gradual. Z3 is even more strongly welded, (Fig 4e and 4f) with mesoscopic flow structure from ductile deformation. Extensive devitrification has affected Z3. The devitrified deposit (light color) shows an abrupt color change compared with Z2 (brown color). Despite the intense welding, Z3 contains unwelded, dense pumices, around which the welded pumices (fiammae) are deformed by rheomorphism (Fig 4e). Upwards, Z3 acquires a densely welded,. rheomorphic aspect, the clastic nature of which is still revealed by the occurrence of rare lithic clasts included in the grey pumice spatter and few unwelded pumices (Fig. 4f). As in Z1, Z2 and Z3 deposits are characterised by the absence of any inter-clasts matrix.

\section{Grain-size distribution, bulk density and porosity.}

Vertical variations in the grain-size distribution and modal variations were analysed by selecting a total of 12 representative samples along the non-welded part (Z1) of El Palomar Member (Fig. 5). Results are reported in Table 1. This part of the deposit includes certain vertical variations in the size of pumice clasts (Fig. 3) mostly in the middle part, with the largest pumices up to 13-14 cm (Fig. 6). Median diameters (MdФ) show values between $-1.1 \Phi$ and $-3.5 \Phi$. In general, most of the Z1 deposit is poorly sorted (between 2.1 $\Phi$ and $2.7 \Phi$ ) although in some parts it appears better sorted with values between $1.3 \Phi$ and $1.8 \Phi$. Skewness values are positive to very positive $(0.18 \Phi$ $-0.45 \Phi)$. Concerning fine material, F1 $[\mathrm{wt} . \%<1 \mathrm{~mm}$ diameter $(0 \Phi)]$ has values between $8 \%$ and $23 \%$ and $\mathrm{F} 2$ [wt.\% $<1 / 16 \mathrm{~mm}$ diameter $(4 \Phi)$ ], between $2 \%$ and $9 \%$. Because the existence of welding among pumice fragments it was not possible to make the same grain size analysis for the rest of the deposit (zones Z2 and Z3). However, in this welded part it was possible to measure the apparent maximum elongation of pumice fragments, revealing a progressive increase from a few centimetres at the base of $\mathrm{Z} 2$ to nearly $1 \mathrm{~m}$ at the top of $\mathrm{Z3}$.

Profiles of bulk density and porosity were performed on 22 samples through the whole El Palomar Member by Soriano et al. (2002), and we also use these data here (Fig. 5). Porosity mainly 
decreases up-section while bulk density increases, probably as a consequence of the up-wards increase in the degree of welding. A slight increase in porosity is observed at the base of the densely welded facies, but absolute values of porosity for this densely welded sector (Z2 and Z3) are always lower than those of the non-welded zone (Fig. 5).

\section{Texture and Mineralogy}

Phonolites from the El Palomar fallout succession are crystal-poor (0.7-5.5\%) porphyritic glassy rocks containing crystals of alkali feldspar, biotite, clinopyroxene, sodalite, Fe-Ti oxides, apatite, and the extremely rare kaersutite of inferred xenocrystic origin (i.e., coming from more mafic magmas during previous episodes of intrusion, Zafrilla (2001)). Phenocryst content is $0.7 \%$ in the non-welded facies, and it may reach up to $5.5 \%$ in the densely welded facies. Three different sample types have been studied showing distinct textural characteristics but with the same mineral assemblage throughout the sequence: juvenile pumice fragments from $\mathrm{Z1}$, welded pumices from Z3, and lava-like fragments from Z3.

Pumices from Z1 are mainly highly vesicular white pumices. Toward the top of this part of the deposit the vesicularity of the juvenile pumice clasts diminishes and the deposit contains not only white pumices but also brown and streaky pumices, the latter being moderately to poorly vesicular (Fig. 4b). The brown and streaky pumice are crystal-poor porphyritic glassy rocks with scarce phenocrysts of alkali feldspar, biotite, clinopyroxene and Fe-Ti oxides. Alkali feldspar is the dominant mineral phase and occurs chiefly as subhedral phenocrysts or crystal fragments. Fractured phenocrysts are common. Intergrowths with alkali feldspar, clinopyroxene, biotite and Fe-Ti oxides are present. Biotite may have rounded crystal margins and include Fe-Ti oxides. Clinopyroxene phenocrysts vary from euhedral to anhedral and can include acicular apatite and biotite. In the uppermost part of Z1 clinopyroxene phenocrysts can have rounded margins and reaction rims. Subhedral to anhedral Fe-Ti oxides are present as well in the pumices throughout Z1. Occasionally they show rounded margins. Subhedral plagioclase phenocrysts occur also in the upper part of Z1. Euhedral sodalite is present throughout $\mathrm{Z1}$ while rare euhedral kaersutite and titanite occur in its 
uppermost part. The glassy groundmass contains rare biotite and alkali feldspar microlites, which are more abundant in the brown pumices from the upper part of $\mathrm{Z} 1$. In some samples the groundmass is partly devitrified or may show patchy oxidised zones. Variation in the abundance of vesicles and microlites in some pumices defines flow bands. Sub-trachytic textures are also observed.

Welded pumices are porphyritic and poorly vesicular. Euhedral to subhedral phenocrysts are set in a brownish glassy groundmass. The groundmass includes alkali feldspar microlites, which are aligned following the flow direction, with molding phenocrysts and pumice clasts morphologies. The phenocryst observed are alkali feldspar, biotite, Fe-Ti oxides, and clinopyroxene. Phenocrysts morphologies vary from euhedral to anhedral, the presence of crystal fragments being common.

Lava-like fragments correspond to strongly welded and stretched pumices that mostly form Z3 (Fig. 4f). They are partially or totally devitrified and are porphyritic, poorly vesicular glassy (devitrified) pumice fragments, which include phenocrysts of alkali feldspar, biotite, clinopyroxene, Fe-Ti oxides, and sodalite. Acicular apatite may be included in clinopyroxene phenocrysts. Subhedral phenocrysts of alkali feldspar and clinopyroxene commonly show resorption textures and they are sometimes intergrown with Fe-Ti oxides. Biotite and Fe-Ti oxides occur as subhedral phenocrysts. Sodalite phenocrysts are euhedral. Relict pumices can be distinguished in the partly devitrified, glassy matrix.

\section{Whole rock geochemistry}

El Palomar pumices are sodic, moderately alkaline, and silica undersaturated, with $\mathrm{Na} / \mathrm{K}=$ 1.2-2.8 and an agpaitic index $([\mathrm{Na}+\mathrm{K} / \mathrm{Al}])=0.6-1.3$. Due to the volatility of alkali metals $(\mathrm{Na}, \mathrm{K})$, samples have been carefully screened for the effects of alteration. Evidence of alteration for some samples was expected for two reasons. First, pumice clasts are porous and permeable, favouring alkali loss and Fe oxidation by percolating fluids. Second, welded rocks emplaced at relatively high temperatures are typically affected by vapor phase alteration, devitrification, and Fe oxidation 
processes (Noble, 1965). The main expected effect of such processes is a decrease in total alkali content, and a correlative enrichment in other components, the largest of which will be for the major oxides $\mathrm{SiO}_{2}$ and $\mathrm{Al}_{2} \mathrm{O}_{3}$. However, other major, trace, and rare earth elements should be essentially unaffected by alteration (Cox et al., 1979).

El Palomar pumices have $\mathrm{SiO}_{2}$ contents ranging from 60.3-62.3 wt $\%$ and $\mathrm{Al}_{2} \mathrm{O}_{3}$ contents of 20-18.8 wt $\%$. The samples studied have $\mathrm{Na}_{2} \mathrm{O}$ contents ranging from 5.7 to $8.1 \mathrm{wt} \%$, and $\mathrm{K}_{2} \mathrm{O}$ contents between 5.3 and $7.3 \mathrm{wt} \%$ (Table 2). A subtle upward decreasing trend is apparent for $\mathrm{MgO}, \mathrm{TiO}_{2}, \mathrm{CaO}$, and $\mathrm{P}_{2} \mathrm{O}_{5}$ (Fig. 7a) from base to top along the $\mathrm{Z1}$ and $\mathrm{Z} 2$ units, while the capping $\mathrm{Z3}$ shows an abrupt enrichment of these elements (Fig. 7 and Table 2). The $\mathrm{SiO}_{2}$ variation is characterised by a relatively constant value in $\mathrm{Z1}$, followed by a decreasing trend upwards from the top of $\mathrm{Z} 2$ and towards the top of $\mathrm{Z} 3$. MnO abundances are more or less constant in $\mathrm{Z} 1$ and decrease in $\mathrm{Z} 2$, increasing again in $\mathrm{Z3} . \mathrm{Na}_{2} \mathrm{O}$ abundances show an enrichment from the base of $\mathrm{Z} 1$ to the top of $\mathrm{Z} 2$ and a decrease in $\mathrm{Z} 3 . \mathrm{K}_{2} \mathrm{O}$ abundances show the same trend described for $\mathrm{Na}_{2} \mathrm{O}$.

Small variations in some major element contents are observed in the levels where different juvenile products (white, brown, and streaky pumices) have been sampled. White, brown and streaky pumices in the uppermost part of $Z 1$ show only a subtle variation in most major oxides, the white pumices being relatively enriched in $\mathrm{SiO}_{2}, \mathrm{TiO}_{2}$, and $\mathrm{K}_{2} \mathrm{O}$, while being depleted in $\mathrm{Al}_{2} \mathrm{O}_{3}$ and $\mathrm{Na}_{2} \mathrm{O}$. Brown pumices are relatively enriched in $\mathrm{MgO}$ and $\mathrm{Na}_{2} \mathrm{O}$.

Samples from $\mathrm{Z} 1$ to $\mathrm{Z} 3$ are relatively depleted in $\mathrm{Zr}$ and $\mathrm{Rb}$ but are significantly enriched in $\mathrm{Ba}$ and $\mathrm{Sr}$. The capping sample from $\mathrm{Z3}$ is enriched in $\mathrm{Ba}, \mathrm{Sr}$, and $\mathrm{Cr}$ but is depleted in $\mathrm{Nb}$. Some of the samples from Z1 and Z2 and samples from Z3 are Cr-rich. Samples from Z1 have fairly constant trace element abundances up-section. Some samples from $\mathrm{Z} 1$ have $\mathrm{Zr} / \mathrm{Nb}$ ratios of 2.6 on average while samples from $\mathrm{Z} 2$ have $\mathrm{Zr} / \mathrm{Nb}$ ratios of 3.9. White, brown and streaky pumices were sampled in the upper part of Z1 from the same stratigraphic level. The streaky pumices are slightly more enriched in $\mathrm{Zr}$ and $\mathrm{Rb}$ contents, while brown pumices are more enriched in $\mathrm{Cr}$ contents (Fig. $7 \mathrm{~b}$ and Table 2). 
REE contents were normalised to chondrite values using the normalisation coefficients of Taylor and McLennan (1985). The El Palomar samples exhibit a strong Light Rare Earth Element (LREE) enrichment, with $L a_{N} / Y_{N}$ ranging from 12 to 33. A negative Eu anomaly characterises these samples, which show a $\mathrm{Eu} / \mathrm{Eu}_{\mathrm{N}}$ ratio of 2.6. Moreover, these samples are relatively enriched in MREE compared to other phonolites from Las Cañadas (Zafrilla, 2001) and show high $\mathrm{Sm}_{\mathrm{Cn}} / \mathrm{Gd}_{\mathrm{Cn}}$ ratios (Table 2)

\section{Portable in situ XRF data}

The vertical compositional trends observed throughout the El Palomar sequence are in general reproduced in the in situ portable XRF data when associated analytical errors are considered (Fig. 7, Table 2). In detail, XRF in situ data reasonably matches the $\mathrm{TiO}_{2}, \mathrm{CaO}, \mathrm{Fe}_{2} \mathrm{O}_{3}, \mathrm{Nb}$, and $\mathrm{Zr}$ concentrations determined by laboratory XRF methods, while the difference between in situ and laboratory XRF increases for $\mathrm{SiO}_{2}, \mathrm{Al}_{2} \mathrm{O}_{3}, \mathrm{MnO}, \mathrm{K}_{2} \mathrm{O}, \mathrm{Y}$, and $\mathrm{Rb}$, and achieves erratic values for $\mathrm{MgO}, \mathrm{Sr}$, and $\mathrm{V}$.

\section{Intensive parameters}

The crystal-poor character of the phonolitic products $(\leq 5.5 \mathrm{vol} . \%)$ prevented finding enough magnetite-ilmenite pairs to apply the Fe-Ti oxide geothermometer in order to estimate the pre-eruptive temperature $(\mathrm{T})$ and oxygen fugacity $\left(f \mathrm{O}_{2}\right)$. Although eleven pairs were found within the different thin sections of the products, none of them passed the equilibrium test of Bacon and Hirschmann (1988), suggesting either crystal inheritance upon mixing or a thermal perturbation shortly prior to eruption that affected FeTi oxides primarily owing to their propensity to rapidly record new conditions, although not at the same rate for ilmenite and magnetite (e.g.,Venezsky and Rutherford, 1999; Scaillet and Evans, 1999). The determination of intensive parameters can still be made by comparing the phase assemblage and compositions of the rocks with available phase equilibrium data from Tenerife phonolites (Andújar et al., 2008, 2010, 2013; Andújar and Scaillet, 
2012). To assess the pre-eruptive temperature of the Palomar phonolitic magmas, we have linearly regressed the variation of $\mathrm{CaO}, \mathrm{TiO}_{2}$, and $\mathrm{FeO} *$ melt contents (calculated as raw $\mathrm{Fe}_{2} \mathrm{O}_{3} * 0.899$, Table 2) with the experimental temperature using the phase equilibrium experiments performed by Andújar et al. (2008, 2010, 2013) and Andújar and Scaillet (2012) on compositionally similar Tenerife phonolitic magmas. To this end, we derived the following simple empirical equation:

$\mathrm{T}^{\circ} \mathrm{C}=131.268 * \mathrm{CaO}(\mathrm{wt} \%)+200.012 * \mathrm{TiO}_{2}(\mathrm{wt} \%)-31.272 * \mathrm{FeO}^{*}(\mathrm{wt} \%)+725.611\left(\mathrm{R}^{2}=0.95\right)$ eq.1

This equation back-calculates the temperature of the phonolitic liquids used for calibration to within $\pm 16^{\circ} \mathrm{C}$, and is valid for the $700-925^{\circ} \mathrm{C}$ temperature interval. It should be stressed that this equation retrieves temperatures of phonolitic rock samples having low crystal content $(\leq 15$ vol\%), which ensures near-liquidus conditions. Applying this equation to phonolites with higher crystal contents (i.e., for residual liquids with compositions significantly different from those of the corresponding whole rock) may provide spurious results (i.e., overestimated temperatures). Alternatively phrased, considering that all elements used in the regression decrease with fractionation, the calculated temperatures for crystal-bearing phonolites are always maximum.

The temperature of the succession forming Z1 deposit was calculated with this equation using laboratory XRF WR, yielding an average temperature of $879 \pm 18^{\circ} \mathrm{C}$ (Fig. 8, Table 2). No temperature difference was noted between pumice- and obsidian-like material analysed at the same level. A minimum value of $837^{\circ} \mathrm{C}$ was computed at the bottom of the sequence, then $\mathrm{T}$ slightly increases upwards from $850^{\circ} \mathrm{C}$ until reaching a maximum value of $\sim 890^{\circ} \mathrm{C}$ mid succession. Thereafter, the temperature slightly decreases to an average value of $870^{\circ} \mathrm{C}$, to increase again to $890^{\circ} \mathrm{C}$ and then remains constant (within analytical errors) until the top of this phonolitic succession. Additionally, we also calculated the $\mathrm{T}$ of the $\mathrm{Z} 1$ succession using the $\mathrm{TiO}_{2}$ melt content dependence with temperature, which was experimentally observed on Ca-rich phonolitic magmas of 
the Eiffel complex (Germany; Berndt et al. 2001). This parameterisation yields a somewhat hotter T of 890 to $>920^{\circ} \mathrm{C}$ for El Palomar magmas, the difference probably being due to the difference in whole rock compositions used for both calibrations. For comparison, temperatures calculated with the in situ portable XRF raw data are also shown, as derived from eq. 1 (Fig. 8, Table 2). Apart from two extreme $\mathrm{T}$ values of $1100-1200^{\circ} \mathrm{C}$ that were retrieved at the uppermost part of the stratigraphical log, there is a general good correspondence between both sets of temperatures. The two outliers in $\mathrm{T}$ come from the $\mathrm{CaO}$ contents obtained from the portable apparatus, which form spikes on some of the horizons (Fig. 7a).

Although we could not determine the temperature of the 5 welded layers $(\mathrm{Z} 2-\mathrm{Z} 3)$ by $\mathrm{Fe}-\mathrm{Ti}$ oxide geothermometry, the similarity in composition of these welded horizons with other tephriphonolitic magmas of the same volcanic system, for which a $\mathrm{T}$ of $\sim 1050^{\circ} \mathrm{C}$ was determined (Bryan et al., 2002), suggests a similar $\mathrm{T}$ for this level. Temperatures $\geq 1000^{\circ} \mathrm{C}$ are also supported by the experimental results of Iacovino et al. (2016) for phonotephritic magmas which, at these temperatures, produce tephriphonolitic-mafic to phonolitic melt compositions that broadly encompass those observed in $\mathrm{Z} 2$ and $\mathrm{Z} 3$. Thus, our results show a broadly thermally homogeneous $\mathrm{Z1}$, capped by much hotter Z2-Z3 layers $\left(\sim 1000 \pm 50^{\circ} \mathrm{C}\right)$.

With the temperature estimated as above, the mineral assemblage characteristic of the phonolitic El Palomar magmas can now be used to assess the pressure of the magma reservoir. The assemblage alkali feldspar, biotite, clinopyroxene, titanite, sodalite, Fe-Ti oxides, and apatite is characteristic of highly evolved phonolitic magmas of Tenerife (see Wolff et al., 2000; Bryan et al., 2002; Edgar et al., 2007) and allows direct comparison with existing phase equilibrium data gathered from a compositionally similar phonolitic eruption (Andújar et al., 2008). Considering the thermal interval inferred above for El Palomar phonolitic magmas $\left(830-890^{\circ} \mathrm{C}\right)$, their crystal-poor character, and by assuming a 3-4 wt $\%$ melt $\mathrm{H}_{2} \mathrm{O}$ content (significantly higher $\mathrm{H}_{2} \mathrm{O}$ content would inhibit clinopyroxene and feldspar crystallisation in that temperature interval, see Andujar et al., (2013)), which is characteristic of Tenerife phonolitic magmas (Andújar et al. 2008, 2013), we can 
constrain a pressure range of $100 \pm 50 \mathrm{MPa}$ for the production of the El Palomar mineral assemblage. These shallow conditions resemble those previously determined for other Tenerife phonolites, and are essentially constrained by the presence of sodalite, a mineral that, along with haüyne, set an uppermost pressure value of $150 \mathrm{MPa}$ for magma crystallisation (Andújar et al. 2008).

\section{Discussion}

On the light of the data presented above, we can now discuss on whether the physicochemical variations observed in stratigraphic succession of the El Palomar Member reflect changes existing in the magma chamber prior to eruption, or respond to processes occurring in the eruptive conduit, or both. Also, it is important to envisage, in case the changes observed in the deposit mirror the internal structure of the magma chamber prior to the eruption, how this affected the eruption dynamics.

The case of El Palomar Member is not the only one showing the existence of zonation in phonolitic magma chambers in Tenerife. Previous studies have already pointed out on the existence of such phenomena in other Las Cañadas eruptions (e.g., Fasnia, Wolff and Storey, 1984, Edgar et al., 2017; Granadilla, Bryan et al., 2000), also suggesting that injection of more mafic magmas into a compositionally zoned phonolitic magma reservoir was a common mechanism to trigger Las Cañadas explosive eruptions. This situation has been described at Teide and Pico Viejo (Ablay et al., 1995, 1998), so understanding what happened during the construction of Las Cañadas complex may provide the clues to understand and anticipate the future behaviour of Teide-Pico Viejo

Zonation of magma chambers is a common process that has been described for many volcanic centres, including phonolitic ones (Vesuvius, Laacher See, Tambora) (Tait 1988; Cioni et al., 1995; Cioni, 2000). Identifying the causes for the preservation of zonation in erupted products is crucial to understanding eruption dynamics and the behaviour of the reservoir prior and during the eruption. 
Magma zoning can correspond to the juxtaposition of magmas of contrasted compositions and physical properties in the same reservoir, or to the development of compositional and density gradients in an originally homogeneous magma due to its internal differentiation (i.e., by fractional crystallisation through crystal settling, or by double diffusive convection). The existence of either sharp or smooth chemical gradients has obviously different implications in terms of magma dynamics. While the first case suggests a relatively short time scale for magma coexistence that allows macroscopic identification of blended magmas from hand samples, the second suggests a sufficiently long lasting process to allow magma differentiation. In a similar way, the fact that any of these zonations are preserved or not in the erupted products also implies different eruption dynamics, particularly concerning the way in which the magma chamber withdraws. In this sense, contrasted models implying either a progressive sequential emptying of the magma chamber that allows the compositional stratigraphy of the chamber to be inverted by the eruptive process (e.g., Blake, 1981b; Spera, 1984), or a chaotic withdrawal implying possible overturning and syn-eruptive mixing between diverse magma compositions (e.g., Folch et al., 1998) have been proposed, both being supported by natural examples.

In the case of El Palomar Member, lithological and compositional vertical variations along the whole deposit offer insights into the structure of the magma chamber just before the onset of the eruption and how magma was withdrawn. The thickness of the deposit, the relative large size of the pumice fragments, and the position of the studied outcrop on the caldera border, indicate its proximal character. The whole stratigraphic succession shows a continuous deposition of pumice fragments, without any minor (layering, bedding) or major (erosional surfaces, paleosoils) stratigraphic discontinuity. This suggests that the succession was deposited during a single, sustained eruption, rather than in different pulses or phases. The grain supported character of the whole deposit and the total absence of any inter-clasts matrix, as well as the grain size homogeneity shown at horizontal level, confirms its fallout character. However, variations in grain size, density, 
degree of welding of the pumice fragments along the studied vertical profile, reveal that some changes in eruption dynamics occurred during the deposition of El Palomar Member.

The almost continuous vertical compositional and mineralogical variations through the main plinian fall unit (Z1 and Z2 in U2) (Fig. 3) argues against any major compositional gaps or abrupt compositional interfaces, and implies a slight pre-eruptive zonation of the phonolite in terms of composition (minor and trace element abundances, mineral chemistry, volatiles) and temperature. $\mathrm{Z} 1$ deposit, which represents the main part of the eruption, is rather homogeneous in terms of lithology and grain-size distribution, which suggests that significant changes did not occur in the chamber and conduit during that phase of the eruption. However, the progressive increase in the degree of welding that characterises the uppermost part of this deposit and Z2 and Z3, is consistent with the withdrawal of progressively hotter and less volatile-rich magma during that part of the eruption, rather than changes occurring in the conduit, as no evidence (variation in lithics content, sudden variation in grain size, etc) exists to support the latter hypothesis.

The lithological and depositional characteristics of the Palomar fallout deposits observed in the field, as well as its grain-size analysis, indicate that these deposits derived from a quasi-steady subplinian to plinian (?) eruption column during Z1, which then waned and changed into a lower intensity fire fountain in Z2 and Z3, which was associated with a progressive lower degree of fragmentation, thus giving rise to the gradual deposition of larger pumice fragments. As already stated, the grain size and density variations of pumice fragments along the stratigraphic profile suggest that this eruption was characterised by a single magmatic episode, as indicated by the presence of highly vesicular juvenile fragments, and a low proportion of fine particles (F1 values between $8 \%$ and $23 \%$ and F2 values between 2\% and 9\%; Table 1 and Fig. 5). The lack of internal bedding and having either normal or inverse grading both indicate steady growth of the eruption column without major fluctuations until its climax. This was probably facilitated by the gradual stabilisation of the conduit walls associated with the increasing vent diameter and magma discharge rate (see Houghton and Carey, 2015). The unimodal trend of Z1 samples together with the coarse 
grain size of the deposits (medium diameter values that are more or less consistent with values between $-1.1 \Phi$ and $-3.5 \Phi$; Table 1 and Fig. 5) support the fallout interpretation, as also suggested by the positive skewness values $0.18 \Phi-0.45 \Phi$. Well sorted deposits from the El Palomar eruption show values between $1.3 \Phi$ and $1.8 \Phi$, typical of dry fallout deposits—although some of them are characterised by sorting $>2 \Phi$, which might be related in this case to the proximity of the vent (see Houghton and Carey, 2015). Up to the top of Z1 and for the Z2 and Z3, the size of pumice fragments increases progressively. Nevertheless, this apparent decrease in the degree of magma fragmentation supports a variation in the internal conditions of the magma chamber (e.g., a progressive decrease in volatile content, a decrease in viscosity, increase in temperature, etc.) rather than being due to changes in the conduit or other parts of the eruptive system. Moreover, bulk density increases upwards, inversely proportional to porosity, as a consequence of the degree of welding, and this makes difficult to correlate this with a primary density gradient. However, the existence of a density gradient in the magma chamber is supported by the change in composition along the sequence.

Taken altogether, mineralogical and geochemical evidence indicate that the physical gradients observed are controlled by compositional changes in the pre-eruptive magma. The phenocryst content changes upwards in the pyroclastic succession, being less than $1 \%$ in the nonwelded part and increasing upwards to $5.5 \%$ in the welded part. Moreover, vertical (in stratigraphic order) trace element plots (Fig. 7) also show the existence of gradual vertical chemical variations, which cannot be explained only considering the upward increase in phenocrysts: for instance, by adding $\sim 5.5 \%$ crystals in the observed proportions to the composition of the lower part of the deposit, we do not obtain compositions similar to those from the uppermost part (Z3). Finally, T-P constraints support a thermally-compositionally zoned and relatively shallow magma reservoir operating prior to the El Palomar eruption.

The onset of El Palomar eruption is marked by the deposition of a poorly sorted, coarse grained pumice horizon with coarse lithic fragments, which rests on the erosion surface formed at 
the top of the U1 deposit, which corresponds to a different eruption. The bulk of the magma erupted was the most evolved of the whole succession (highest $\mathrm{Zr}$ and $\mathrm{Rb}$ contents). The eruption continued with the deposition of the main part of the pumice fallout deposit tapping a chemically similar magma, but relatively less evolved than that from the initial layer. Towards the top of this fallout deposit the erupted magma had lower $\mathrm{Zr}$ and $\mathrm{Rb}$ contents, having been at that time relatively more mafic. This deposit grades upwards into a moderately to strongly welded deposit, which includes the least evolved magma erupted throughout the sequence, having the lowest $\mathrm{Zr}$ contents and being enriched in $\mathrm{Ba}$ and $\mathrm{Sr}$, suggesting a tephri-phonolite composition. Therefore, the eruption of $\mathrm{El}$ Palomar involved a chemically zoned magma chamber, first tapping the most evolved cap, followed then by the eruption of a broadly homogeneous phonolite, and ending with the eruption of a much hotter tephri-phonolite.

This chemical zonation also correlates with a change in the physical properties of the erupted magma in the same direction. The first tapped magma was lighter, possibly richer in volatiles and cooler, while towards the top much hotter, possibly less volatile-rich, and denser magma was erupted. This correlates with a decrease in the intensity of the eruption, lowering the height of the eruption column and reducing the degree of magma fragmentation, as it is indicated by the upwards increase in the size of pumice fragments, thus progressively forming larger and denser pumice fragments that fell down while hotter, leading to their stretching and welding. We do not consider that the change in porosity and density of pumice clasts can be simply explained by changes in vesiculation and fragmentation processes within the conduit. In the same way, this would not explain the chemical gradients observed in the same sense. The transition from a sustained eruption column fallout to spatter fountaining, as already suggested by Soriano et al (2002), we agree that it is the result of the progressive consumption of the volatiles that were exsolved and to the eruption of hotter, less viscous, and denser magma, involving a progressive lowering of the column height and a higher accumulation rate. 
The occurrence of the welded and non-welded pumice in the same layers is a remarkable feature of the El Palomar deposit, which indicates that there was not sufficient time during eruption for the different magma compositions to thermally equilibrate. There is not a limit to the size range for which pumices weld or not, as in the intermediate zone (Z2) of the deposit welded and nonwelded pumices have similar sizes, but the size of deformed (flattened) pumices increases progressively towards the top of the deposit (Z3). However, there are compositional differences between non-welded and welded pumices, being the first similar to those from Z1, while the welded ones correspond to the slightly more mafic compositions of Z2 and Z3 (Zafrilla, 2001). This suggests that fragments from different parts of the magma chamber were erupted simultaneously.

The fact that a broadly constant temperature is expressed by $\mathrm{Z} 1$ suggests that a volume of evolved magma was stored for a relatively long time under stable conditions, and at shallow depths without being perturbed by intrusions of new magma, and developing a slight internal zonation by gravitational processes. The increase in temperature documented between the uppermost part of Z1 and $\mathrm{Z} 2$ and $\mathrm{Z} 3$ suggests intrusion of a hotter magma layer beneath $\mathrm{Z} 1$ followed by rapid extrusion of the whole package; indeed, the protracted juxtaposition of $\mathrm{Z} 1$ with the $\mathrm{Z} 2$ and $\mathrm{Z} 3$ would have rapidly smoothed out the thermal gradient evidenced above. A simple calculation on the contact time between the two layers (the resident, cooler magma on top, and the new, hotter magma below) can be performed using the standard equation of thermal diffusion length (e.g., Turcotte and Schubert, 2002): $\mathrm{x}=(\mathrm{D} \cdot \mathrm{t})^{1 / 2}$, where $\mathrm{x}$ is the distance in meters, $\mathrm{D}$ is the heat diffusivity, $\left(10^{-7} \mathrm{~m}^{2} \mathrm{~s}^{-1}\right)$ and $\mathrm{t}$ is the time of contact in seconds. This allows assessing the depth over which $\mathrm{Z} 1$ could have been heated following the $\mathrm{Z} 3$ intrusion. Taking the distance between the last measured point in $\mathrm{Z} 2$ and the first measured one in $\mathrm{Z} 3(0.5 \mathrm{~m})$ yields a time duration of about 25 days, which should be taken as a maximum contact time before eruption (given the possibility that the distance could be shorter than the measured one). Alternatively, though injection of tephri-phonolite is our preferred model, it could be considered that the coexistence of two contrasted magma layers reflects the operation of double diffusive convection in the reservoir (Huppert and Turner, 1981). Physical 
modelling of such a process in magma reservoirs (Huppert and Sparks, 1981) has shown that the sharp interface between the two layers does not exceed a few $\mathrm{cm}$ in thickness and that the thermal gradient across it cannot survive for more than a few months (i.e., 5 months for a temperature difference of $130^{\circ} \mathrm{C}$ ), ie a time lapse similar to the injection model. Future studies should look in greater detail at the petrology of the contact zone, to detect whether mineral textures in $\mathrm{Z} 1$ indeed recorded such an intrusion of hot magma; nonetheless, the occasional occurrence of rounded phenocrysts (clinopyroxene, biotite, oxides) does support such a mechanism. Altogether, regardless of which mechanism operated, the crystal-poor character of both end-members and available physical evidence point to a restricted contact time between phonolite and tephri-phonolite prior to eruption, on the order of several weeks to a few months.

This internal zonation of the El Palomar magma chamber was maintained until the onset of the eruption and partially during it. The presence of pumices of slightly different compositions in the same stratigraphic levels suggests however, that magma withdrawal affected different stratigraphic levels inside the chamber, thus tapping different depths at the same time but without changing the internal configuration of the chamber, in a similar way to the one proposed by Blake (1981b) (Fig. 9).

In summary, the succession of events that characterise the El Palomar eruption can be described as follows: i) a shallow magma chamber was fully occupied by phonolitic magma, showing a slight density and compositional zoning caused by differentiation in a closed system; ii) injection of a hotter more mafic magma raised the internal pressure of the chamber, thus leading the resident magma to eruption conditions in a relatively short time of a few weeks. iii) at the contact zone between the two magmas heat transfer started before eruption, causing an initial thermal interaction that is now observed by the presence of a few rounded phenocrysts (clinopyroxene, biotite, oxides) at the upper part of the $\mathrm{Z1}$ deposit; iv) the eruption occurred before sufficient time passed to allow mixing and/or overturning in the chamber, so its internal zoned structure was maintained.. 
This eruption occurred in a similar way to that predicted by the theoretical model of Blake (1981b), so the magma was tapped through compositional isochrones, thus causing deposition at the same stratigraphic level of pumices representing different parcels of the magma chamber. When magma withdrawal reached the deepest parts of the chamber and the new magma started to erupt together with the host magma, both collapsed and expanded pumices in the same stratigraphic level progressively appearing together. This situation continued with an increasing proportion of fragments derived from the hotter magma until the end of the eruption. The fact that the preeruptive internal structure of the magma chamber was maintained throughout the whole eruption suggests that the eruption occurred under steady conditions, without being altered by any external changes (e.g., changes in the eruption conduit). The gradual transition observed towards the end of the eruption (from the eruption column to fire fountaining) was entirely due to the changes in composition and physical properties (i.e., gas content, temperature, viscosity, density) of the erupted magmas.

Beyond the volcanological implications, it is worth mentioning that the in situ measurements made with the use of the portable XRF were broadly satisfactory. Although the results obtained compared to the whole rock data gathered using traditional analytical methods show important variations for some elements $(\mathrm{Si}, \mathrm{Mg}, \mathrm{Al})$, a more than reasonable match is observed for other, heavier, elements (Ti, Fe, Ca, K, Zr). Our results validate the in situ portable XRF method for measuring elements that track the fractionation process of phonolitic systems (CaO, Fe2O3, Nb, Zr; Ablay et al., 1998; Wolff et al., 2000). They confirm that this portable tool is a good option for rapid identification of differences in rock composition in the field, particularly in the case of fine grained or crystal-poor volcanic rocks, thus becoming a good option for in situ geochemical correlations in stratigraphic studies or to establish geochemical variations within single deposits, such as the one studied here, directly in the field. The in situ analytical approach will improve geological mapping or stratigraphic correlation campaigns by reducing the number of samples needed for lab characterisation. At this stage in the development of in situ XRF devices, 
they should not be operated alone and should be always coupled with laboratory XRF measurements for detailed geochemical studies.

\section{Conclusions}

Field observations, T-P constraints and compositional analysis point towards a thermallycompositionally zoned and relatively shallow magma chamber structure operating prior to the El Palomar eruption. The eruptive mechanism and magma withdrawal that generated the El Palomar sequence seems to have been related to the arrival of a hot and more mafic magma that triggered the eruption, as documented for many other volcanic centres during the construction of the Las Cañadas central complex and currently at Teide-Pico Viejo stratovolcanoes, and elsewhere. The data reported here suggest a relatively short contact time between resident and invading magmas, on the order of several weeks to a few months, although such an estimate needs to be refined. By comparison, this short time implies that anticipating the next eruptive events produced by magma mixing at Teide-Pico Viejo will require careful and continuous data monitoring in order to be able to detect magma intrusions into the shallow reservoir, such as geodetic or gravimetric changes, before the magma chamber ruptures.

\section{Acknowledgements}

We thank the Teide National Park for allowing us to undertake this research and María José Blanco and Stavros Meletlidis for logistical help during the field work. JM is grateful for a Laureate grant for the program "Make our planet great again", Campus France, France. We thank the two JVGR referees for their constructive and helpful reviews. English text was corrected by Grant George Buffett (www.terranova.barcelona).

\section{References}

Ablay, G.J., Ernst, G.G.J., Marti, J. and Sparks, R.S.J., 1995. The $~ 2$ ka subplinian eruption of Montaña Blanca, Tenerife. Bulletin of Volcanology, 57(5), pp. 337-355. 
Ablay, G.J., Carroll, M.R., Palmer, M.R., Martí, J. and Sparks, R.S.J., 1998. Basanite-phonolite lineages of the Teide-Pico Viejo volcanic complex, Tenerife, Canary Islands. Journal of Petrology, 39(5), pp. 905-936.

Ancochea, E., Fuster, J., Ibarrola, E., Cendrero, A., Coello, J., Hernan, F., Cantagrel, J.M. and Jamond, C., 1990. Volcanic evolution of the island of Tenerife (Canary Islands) in the light of new K-Ar data. Journal of Volcanology and Geothermal Research, 44(3-4), pp. 231-249.

Andújar, J. and Scaillet, B., 2012. Experimental constraints on parameters controlling the difference in the eruptive dynamics of phonolitic magmas: the case of Tenerife (Canary Islands). Journal of Petrology, 53(9), pp. 1777-1806.

Andújar, J., Costa, F. and Martí, J., 2010. Magma storage conditions of the last eruption of Teide volcano (Canary Islands, Spain). Bulletin of Volcanology, 72(4), pp. 381-395.

Andújar, J., Costa, F. and Scaillet, B., 2013. Storage conditions and eruptive dynamics of central versus flank eruptions in volcanic islands: the case of Tenerife (Canary Islands, Spain). Journal of Volcanology and Geothermal Research, 260, pp. 62-79.

Andújar, J., Costa, F., Martí, J., Wolff, J.A. and Carroll, M.R., 2008. Experimental constraints on pre-eruptive conditions of phonolitic magma from the caldera-forming El Abrigo eruption, Tenerife (Canary Islands). Chemical Geology, 257(3-4), pp. 173-191.

Araña, V., 1971. Litología y estructura del Edificio Cañadas, Tenerife (Islas Canarias). Estudios geológicos, 27, pp. 95-135.

Bachmann, O., Dungan, M.A. and Lipman, P.W., 2002. The Fish Canyon magma body, San Juan volcanic field, Colorado: rejuvenation and eruption of an upper-crustal batholith. Journal of Petrology, 43(8), pp. 1469-1503.

Bacon, C.R. and Hirschmann, M.M., 1988. Mg/Mn partitioning as a test for equilibrium between coexisting Fe-Ti oxides. American Mineralogist, 73(1-2), pp. 57-61. 
Bacon, C.R. and Druitt, T.H., 1988. Compositional evolution of the zoned calcalkaline magma chamber of Mount Mazama, Crater Lake, Oregon. Contributions to Mineralogy and Petrology, 98(2), pp. 224-256.

Bea, F., 2010. Crystallization dynamics of granite magma chambers in the absence of regional stress: multiphysics modeling with natural examples. Journal of Petrology, 51(7), pp. 1541-1569.

Berndt, J., Holtz, F. and Koepke, J., 2001. Experimental constraints on storage conditions in the chemically zoned phonolitic magma chamber of the Laacher See volcano. Contributions to Mineralogy and Petrology, 140(4), pp. 469-486.

Blake, S., 1981a. Volcanism and the dynamics of open magma chambers. Nature, 289(5800), pp. 783-785.

Blake, S., 1981b. Eruptions from zoned magma chambers. Journal of the Geological Society of London, 138(3), pp. 281-287.

Blake, S. and Ivey, G.N., 1986a. Magma-mixing and the dynamics of withdrawal from stratified reservoirs. Journal of Volcanology and Geothermal Research, 27(1-2), pp. 153-178.

Blake, S. and Ivey, G.N., 1986b. Density and viscosity gradients in zoned magma chambers, and their influence withdrawal dynamics. Journal of Volcanology and Geothermal Research, 30(3-4), pp. 201-230.

Bower, S.M. and Woods, A.W., 1998. On the influence of magma chambers in controlling the evolution of explosive volcanic eruptions. Journal of Volcanology and Geothermal Research, 86(14), pp. 67-78.

Brown, R.J., Barry, T.L., Branney, M.J., Pringle, M.S. and Bryan, S.E., 2003. The Quaternary pyroclastic succession of southeast Tenerife, Canary Islands: explosive eruptions, related caldera subsidence, and sector collapse. Geological Magazine, 140(3), pp. 265-288.

Bryan, S.E., Martí, J. and Cas, R.A.F., 1998. Stratigraphy of the Bandas del Sur Formation: an extracaldera record of Quaternary phonolitic explosive eruptions from the Las Cañadas edifice, Tenerife (Canary Islands). Geological Magazine, 135(5), pp. 605-636. 
Bryan, S.E., Cas, R.A.F. and Martí, J., 2000. The 0.57 Ma plinian eruption of the Granadilla Member, Tenerife (Canary Islands): an example of complexity in eruption dynamics and evolution. Journal of Volcanology and Geothermal Research, 103(1-4), pp. 209-238.

Bryan, S.E., Marti, J. and Leosson, M., 2002. Petrology and geochemistry of the bandas del Sur formation, Las Cañadas edifice, Tenerife (Canary Islands). Journal of Petrology, 43(10), pp. 18151856.

Cioni, R., 2000. Volatile content and degassing processes in the AD 79 magma chamber at Vesuvius (Italy). Contrib Mineral Petrol 140, 40-54.

Cioni, R., Civetta, L., Marianelli, P., Metrich, N., Santacroce, R., Sbrana, A. (1995). Compositional layering and syn-eruptive mixing of a periodically refilled shallow magma chamber: the AD 79 Plinian eruption of Vesuvius. Journal of Petrology, 36(3), 739-776.

Coombs, M.L., Eichelberger, J.C. and Rutherford, M.J., 2000. Magma storage and mixing conditions for the 1953-1974 eruptions of Southwest Trident volcano, Katmai National Park, Alaska. Contributions to Mineralogy and Petrology, 140(1), pp. 99-118.

Cox, K.G., Bell, J.D. and Pankhurst, R.J., 1979. The interpretation of igneous rocks. London, Allen and Unwin, $450 \mathrm{pp}$.

Davies, G. F. (2001). Dynamic Earth: Plates, plumes and mantle convection. Cambridge University Press, $250 \mathrm{p}$.

Fagents, S.A., Gregg, T.K. and Lopes, R.M. eds., 2013. Modeling volcanic processes: the physics and mathematics of volcanism. Cambridge University Press, pp. 5-31.

Edgar, C.J., Wolff, J.A., Nichols, H.J., Cas, R.A.F. and Martí, J., 2002. A complex Quaternary ignimbrite-forming phonolitic eruption: the Poris member of the Diego Hernández Formation (Tenerife, Canary Islands). Journal of Volcanology and Geothermal Research, 118(1-2), pp. 99130.

Edgar, C.J., Wolff, J.A., Olin, P.H., Nichols, H.J., Pittari, A., Cas, R.A.F., Reiners, P.W., Spell, T.L. and Martí, J., 2007. The late Quaternary Diego Hernandez Formation, Tenerife: Volcanology 
of a complex cycle of voluminous explosive phonolitic eruptions. Journal of Volcanology and Geothermal Research, 160(1-2), pp. 59-85.

Edgar, C.J., Cas, R.A., Olin, P.H., Wolff, J.A., Martí, J. and Simmons, J.M., 2017. Causes of complexity in a fallout dominated plinian eruption sequence: 312 ka Fasnia Member, Diego Hernández Formation, Tenerife, Spain. Journal of Volcanology and Geothermal Research, 345, pp. $21-45$.

Folch, A., Martí, J., Codina, R. and Vazquez, M., 1998. A numerical model for temporal variations during explosive central vent eruptions. Journal of Geophysical Research: Solid Earth, 103(B9), pp. 20883-20899.

Folch, A., Codina, R. and Martí, J., 2001. Numerical modeling of magma withdrawal during explosive caldera-forming eruptions. Journal of Geophysical Research: Solid Earth, 106(B8), pp. $16163-16175$.

Freundt, A., Tait, S. R., 1986. The entrainment of high-viscosity magma into low-viscosity magma in eruption conduits. Bulletin of Volcanology, 48, 325-339.

Fuster, J.M, Araña, V., Brandle, J.L., Navarro, M., Alonso, U., Aparicio, A., 1968. Geología y volcanología de las islas Canarias: Tenerife. Instituto "Lucas Mallada," CSIC, Madrid, 218 pp.

Hildreth, W., 1979. The Bishop Tuff: Evidence for the origin of compositional zonation in silicic magma chambers. Geological Society of America Special Paper, 180, pp. 43-75.

Hildreth, W., 1981. Gradients in silicic magma chambers: implications for lithospheric magmatism. Journal of Geophysical Research: Solid Earth, 86(B11), pp.10153-10192.

Hildreth, W. and Wilson, C.J.N., 2007. Compositional zoning of the Bishop Tuff. Journal of Petrology, 48(5), pp. 951-999.

Hildreth, W. and Fierstein, J., 2012. The Novarupta-Katmai eruption of 1912: largest eruption of the twentieth century: centennial perspectives (No. 1791). Geological Survey (USGS).

Houghton, B. and Carey, R.J., 2015. Pyroclastic fall deposits. In The Encyclopedia of Volcanoes (pp. 599-616). Academic Press. 
Huppert, H. E., and Sparks, R. S. J. (1981). The fluid dynamics of a basaltic magma chamber replenished by influx of hot, dense ultrabasic magma. Contributions to Mineralogy and Petrology, 75(3), 279-289.

Huppert, H. E., and Turner, J. S. (1981). Double-diffusive convection. Journal of Fluid Mechanics, 106, 299-329.

Huppert, H.E., Sparks, R.S.J., Turner, J.S. and Arndt, N.T., 1984. Emplacement and cooling of komatiite lavas. Nature, 309(5963), pp.19-22.

Iacovino, K., Oppenheimer, C., Scaillet, B. and Kyle, P., 2016. Storage and evolution of mafic and intermediate alkaline magmas beneath Ross Island, Antarctica. Journal of Petrology, 57(1), pp. 93118.

Inman, D.L., 1952. Measures for describing the size distribution of sediments. Journal of Sedimentary Research, 22(3), pp.125-145.

Koyaguchi, T. , 1987. Magma mixing in a squeezed conduit. Earth and Planetary Science Letters, 84, 339-344.

Lindsay, J.M., Schmitt, A.K., Trumbull, R.B., De Silva, S.L., Siebel, W. and Emmermann, R., 2001. Magmatic evolution of the La Pacana caldera system, Central Andes, Chile: Compositional variation of two cogenetic, large-volume felsic ignimbrites. Journal of Petrology, 42(3), pp. 459486.

Marcaida, M., Mangan, M.T., Vazquez, J.A., Bursik, M. and Lidzbarski, M.I., 2014. Geochemical fingerprinting of Wilson Creek formation tephra layers (Mono Basin, California) using titanomagnetite compositions. Journal of Volcanology and Geothermal Research, 273, pp. 1-14.

Martí, I, 2019. Las Cañadas caldera, Tenerife, Canary Islands: A review, or the end of a long $\begin{array}{lllll}\text { volcanological } & \text { controversy. } & \text { Earth-Science } & \text { Reviews } & 196\end{array}$ https://doi.org/10.1016/j.earscirev.2019.102889 
Martí, J. and Gudmundsson, A., 2000. The Las Cañadas caldera (Tenerife, Canary Islands): an overlapping collapse caldera generated by magma-chamber migration. Journal of volcanology and geothermal research, 103(1-4), pp. 161-173.

Martí, J., Mitjavila, J. and Araña, V., 1994. Stratigraphy, structure and geochronology of the Las Cañadas caldera (Tenerife, Canary Islands). Geological Magazine, 131(6), pp. 715-727.

Mourtada-Bonnefoi, C.C., Provost, A. and Albarède, F., 1999. Thermochemical dynamics of magma chambers: A simple model. Journal of Geophysical Research: Solid Earth, 104(B4), pp. 7103-7115.

Oldenburg, C.M., Spera, F.J., Yuen, D.A. and Sewell, G., 1989. Dynamic mixing in magma bodies: theory, simulations, and implications. Journal of Geophysical Research: Solid Earth, 94(B7), pp. 9215-9236.

Scaillet, B., and Evans, B. W. (1999). The 15 June 1991 eruption of Mount Pinatubo. I. Phase equilibria and pre-eruption $\mathrm{P}-\mathrm{T}-\mathrm{f} \mathrm{O} 2-\mathrm{f} \mathrm{H} 2 \mathrm{O}$ conditions of the dacite magma. Journal of Petrology, 40(3), 381-411

Stone, D.B. and Runcorn, S.K. eds., 2013. Flow and Creep in the Solar System: Observations, Modeling and Theory (Vol. 391). Springer Science \& Business Media.

Soriano, C., Zafrilla, S., Martí, J., Bryan, S., Cas, R. and Ablay, G., 2002. Welding and rheomorphism of phonolitic fallout deposits from the Las Canadas caldera, Tenerife, Canary Islands. Geological Society of America Bulletin, 114(7), pp. 883-895.

Soriano, C., Galindo, I., Martí, J. and Wolff, J., 2006. Conduit-vent structures and related proximal deposits in the Las Cañadas caldera, Tenerife, Canary Islands. Bulletin of volcanology, 69(2), pp. $217-231$.

Sparks, R.S.J. and Huppert, H.E., 1984. Density changes during the fractional crystallization of basaltic magmas: fluid dynamic implications. Contributions to Mineralogy and Petrology, 85(3), pp. $300-309$. 
Sparks, R.S.J., Huppert, H.E. and Turner, J.S., 1984. The fluid dynamics of evolving magma chambers. Philosophical Transactions of the Royal Society of London. Series A, Mathematical and Physical Sciences, 310(1514), pp. 511-534.

Spera, F.J., 1984. Some numerical experiments on the withdrawal of magma from crustal reservoirs. Journal of Geophysical Research: Solid Earth, 89(B10), pp. 8222-8236.

Spera, F.J., Yuen, D.A., Greer, J.C. and Sewell, G., 1986. Dynamics of magma withdrawal from stratified magma chambers. Geology, 14(9), pp. 723-726.

Tait, S.R., 1988. Samples from the crystallising boundary layer of a zoned magma chamber. Contributions to Mineralogy and Petrology, 100(4), pp. 470-483.

Taylor, S.R. and McLennan, S.M., 1985. The continental crust: its composition and evolution. Blackwell Scientific Pub., Palo Alto, CA.

Trial, A.F., Spera, F.J., Greer, J., and Yuen, D.A., 1992. Simulations of magma withdrawal from compositionally zoned bodies. Journal of Geophysical Research: Solid Earth, 97(B5), pp. 67136733.

Turcotte, D. L., \& Schubert, G. (2002). Geodynamics. Cambridge University Press., 2nd edition, $456 \mathrm{p}$

Turner, J.S. and Campbell, I.H., 1986. Convection and mixing in magma chambers. Earth-Science Reviews, 23(4), pp. 255-352.

Venezky, D. Y., and Rutherford, M. J. (1999). Petrology and Fe-Ti oxide reequilibration of the 1991 Mount Unzen mixed magma. Journal of Volcanology and Geothermal Research, 89(1-4), 213230.

Wallace, P.J., Anderson Jr, A.T. and Davis, A.M., 1999. Gradients in H2O, CO2, and exsolved gas in a large-volume silicic magma system: Interpreting the record preserved in melt inclusions from the Bishop Tuff. Journal of Geophysical Research: Solid Earth, 104(B9), pp. 20097-20122. 
Weidendorfer, D., Mattsson, H.B. and Ulmer, P., 2014. Dynamics of magma mixing in partially crystallized magma chambers: textural and petrological constraints from the basal complex of the Austurhorn intrusion (SE Iceland). Journal of Petrology, 55(9), pp. 1865-1903.

Wilson, C.J.N., 2008. Supereruptions and supervolcanoes: processes and products. Elements, 4, pp. $29-34$.

Wolff, J.A., Storey, M., 1984. Zoning in highly alkaline magma bodies. Geological Magazine, 121, 563575.

Wolff, J.A. and Ramos, F.C., 2003. Pb isotope variations among Bandelier Tuff feldspars: no evidence for a long-lived silicic magma chamber. Geology, 31(6), pp. 533-536.

Wolff, J.A., Grandy, J.S., and Larson, P.B., 2000. Interaction of mantle-derived magma with island crust? Trace element and oxygen isotope data from the Diego Hernandez Formation, Las Cañadas, Tenerife. Journal of Volcanology and Geothermal Research, 103(1-4), pp. 343-366.

Zafrilla, S., 2001. Relationships between magmatic evolution and phonolitic volcanic activity in the Las Canadas edifice, Tenerife, Canary Islands (Doctoral dissertation, Ph.D. thesis, Universitat de Barcelona). 
Figure 1.- Simplified geological map of Tenerife. Inset: location of Tenerife and the Canary Islands.

White square: sector of the caldera wall represented in Fig. 2.

Figure 2.- Panoramic view of the central sector of the Las Cañadas caldera wall including the El Palomar pyroclastic succession, indicating the main stratigraphic units according to Martí et al. (1994).

Figure 3. General view of the El Palomar outcrop, where the different lithofacies described in the text are indicated.

Figure 4. Details of the El Palomar pyroclastic deposit. a) Erosive contact (black line) between lithofacies L1 and L2 at the base of the succession. b) Detail close to the top of lithofacies L2, where collapsed (cp) and non-collapsed (i.e., expanded) (ep) pumices start to coexist. c) Detail of the uppermost part of lithofacies L2, where most of pumices are collapsed. d) Contact between lithofacies L3 (welded, brown color) and L4 (devitrified, light color). e) Detail of lithofacies L4 where non-collapsed, expanded (ep) pumices are surrounded by strongly welded (stretched) (wp) pumices. f) Detail of the devitrified strongly welded L4 lithofacies.

Figure 5. Stratigraphic profile showing the vertical variations in the grain-size distribution and modal variations along (base to top) the El Palomar sequence. Profiles of bulk density and porosity performed by Soriano et al. (2002) on the same succession, are also shown.

Figure 6. Frequency diagram of the grain size distribution in lithofacies L2 of the El Palomar pyroclastic succession.

Figure 7. Variation of chemical composition along the El Palomar pyroclastic succession. a) Major elements. b) Trace elements. In both cases the composition obtained in the lab (orange color) (see Methodology section) is compared to that obtained with the portable XRF apparatus (blue color, see Methodology section). The degree of correspondence between the two measurements depends on the chemical element and on the detection limit and accuracy of each method for each case. It is obvious that there is no correspondence in some elements, but there is good agreement in others.

Figure 8. Variation of the calculated temperature through the El Palomar pumice fall deposit. 
Figure 9. Cartoon explaining the evolution of the El Palomar phonolitic systems before and during the eruption. a) Situation previous to the injection of new magma: a magma chamber slightly zoned in density and composition because differentiation in a closed system. b) Intrusion of a more mafic and hotter magma causing overpressurisation and initiation of chamber rupture and dyke injection. c) The eruption that occurs before mixing and/or overturning in the chamber can affect its internal structure. Grey circles indicate the withdrawal isochrones (see text for more explanation). 
Table 1. Grain-size analysis.

\begin{tabular}{|c|c|c|c|c|c|c|c|c|}
\hline Sample & $\begin{array}{l}\text { Pumice Max } \\
(\mathrm{cm})\end{array}$ & $\begin{array}{l}\text { Md } \Phi \text { (Medium Diame- } \\
\text { ter) }\end{array}$ & $\begin{array}{l}\sigma \\
\Phi\end{array}$ & Sorting & $\alpha \Phi$ & Skewness & $\begin{array}{l}\mathrm{F} 1[\mathrm{wt} . \%<1 \mathrm{~mm} \text { diameter } \\
(0 Ф)]\end{array}$ & $\begin{array}{l}\mathrm{F} 2[\mathrm{wt} . \%<1 / 16 \mathrm{~mm} \text { diameter } \\
(4 \Phi)]\end{array}$ \\
\hline Palomar 1 & 14 & -1.4 & $\begin{array}{r}2 . \\
7\end{array}$ & $\begin{array}{l}\text { Poorly Sort- } \\
\text { ed }\end{array}$ & $\begin{array}{r}0.2 \\
4\end{array}$ & Positive & 26.8 & 3.4 \\
\hline Palomar 2 & 5 & -1.1 & $\begin{array}{r}2 . \\
2\end{array}$ & $\begin{array}{l}\text { Poorly Sort- } \\
\text { ed }\end{array}$ & 0.4 & $\begin{array}{l}\text { Very Posi- } \\
\text { tive }\end{array}$ & 22.5 & 7.3 \\
\hline Palomar 3 & 8.5 & -1.4 & 3 & $\begin{array}{l}\text { Poorly Sort- } \\
\text { ed }\end{array}$ & 0.4 & $\begin{array}{l}\text { Very Posi- } \\
\text { tive }\end{array}$ & 2.4 & 8.5 \\
\hline Palomar 4 & 6.5 & -1.6 & $\begin{array}{r}2 . \\
4\end{array}$ & $\begin{array}{l}\text { Poorly Sort- } \\
\text { ed }\end{array}$ & $\begin{array}{r}0.4 \\
4\end{array}$ & $\begin{array}{l}\text { Very Posi- } \\
\text { tive }\end{array}$ & 20 & 6.2 \\
\hline Palomar 5 & 8 & -2.3 & $\begin{array}{r}1 . \\
8\end{array}$ & Well Sorted & $\begin{array}{r}0.2 \\
8\end{array}$ & Positive & 11.83 & 2 \\
\hline Palomar 6 & 10 & -2.1 & $\begin{array}{r}2 . \\
1\end{array}$ & $\begin{array}{l}\text { Poorly Sort- } \\
\text { ed }\end{array}$ & 0.3 & Positive & 15.8 & 3.9 \\
\hline Palomar 7 & 13 & -2 & $\begin{array}{r}1 . \\
9\end{array}$ & Well Sorted & $\begin{array}{r}0.3 \\
5\end{array}$ & $\begin{array}{l}\text { Very Posi- } \\
\text { tive }\end{array}$ & 15.9 & 4.9 \\
\hline Palomar 8 & 13 & -2.4 & $\begin{array}{r}2 . \\
2\end{array}$ & $\begin{array}{l}\text { Poorly Sort- } \\
\text { ed }\end{array}$ & 0.4 & $\begin{array}{l}\text { Very Posi- } \\
\text { tive }\end{array}$ & 14.9 & 5.2 \\
\hline Palomar 9 & 9.5 & -3.5 & 2 & $\begin{array}{l}\text { Poorly Sort- } \\
\text { ed }\end{array}$ & 0.4 & $\begin{array}{l}\text { Very Posi- } \\
\text { tive }\end{array}$ & 8.6 & 2.3 \\
\hline $\begin{array}{l}\text { Palomar } \\
10\end{array}$ & 12.5 & -2.5 & $\begin{array}{r}2 . \\
5\end{array}$ & $\begin{array}{l}\text { Poorly Sort- } \\
\text { ed }\end{array}$ & $\begin{array}{r}0.3 \\
7\end{array}$ & $\begin{array}{l}\text { Very Posi- } \\
\text { tive }\end{array}$ & 15.8 & 5.8 \\
\hline $\begin{array}{l}\text { Palomar } \\
11\end{array}$ & 13 & -2.5 & $\begin{array}{r}1 . \\
3\end{array}$ & Well Sorted & $\begin{array}{r}0.3 \\
8\end{array}$ & $\begin{array}{l}\text { Very Posi- } \\
\text { tive }\end{array}$ & 15.1 & 4.5 \\
\hline $\begin{array}{l}\text { Palomar } \\
12\end{array}$ & 8 & -2.8 & $\begin{array}{r}2 . \\
4\end{array}$ & $\begin{array}{l}\text { Poorly Sort- } \\
\text { ed }\end{array}$ & $\begin{array}{r}0.4 \\
4\end{array}$ & $\begin{array}{l}\text { Very Posi- } \\
\text { tive }\end{array}$ & 13.7 & 3.7 \\
\hline
\end{tabular}




\section{Journal Pre-proof}

Table 2. Whole rock analysis and Portable XR fluorescence analysis. Calculated temperatures are also shown.

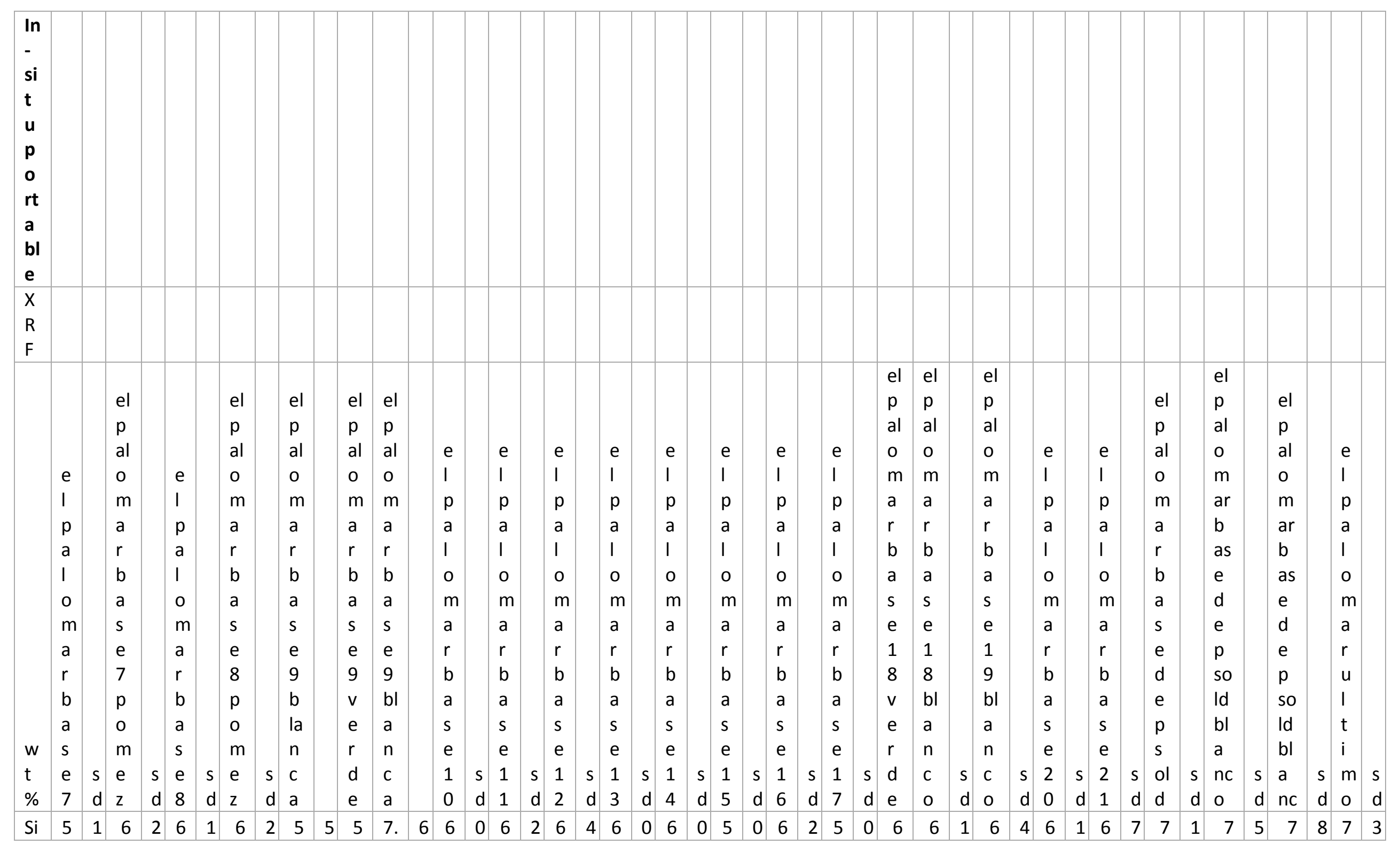




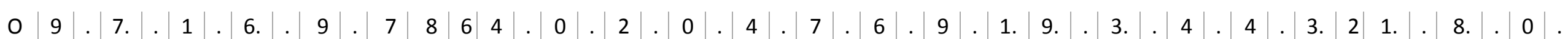
\begin{tabular}{lllllll|llll|llllll|llllllll|l|l|l|l|l|l|l|l|l|l|l|l|l|l|l|l|l|l|l|l|l|l|l}
2 &. & 4 & 1 & 4 &. & 3 & 1 & 9 &. & 9 &. & 5 &. &. & 0 &. & 7 &. & 0 &. & 9 &. & 9 &. & 4 &. & 2 &. & 1 & 7 & 3 & 5 & 2 & 8 &. & 6 &. & 5 & 5 &. & 0 & 0 & 4 & 3 &. & 9
\end{tabular} $\begin{array}{lllllllllllllllllllllllllllllllllllllllllllllllllll}0 & 6 & 2 & 2 & 4 & 6 & 1 & 9 & 0 & 0 & 2 & & 0 & 1 & 8 & 9 & 9 & 7 & 5 & 9 & 8 & 7 & 3 & 6 & 7 & 4 & 9 & 9 & 2 & 0 & 3 & 8 & 2 & 6 & 4 & 2 & 8 & 4 & 3 & 1 & 9 & 8 & 2 & 2 & 6 & 0\end{array}$

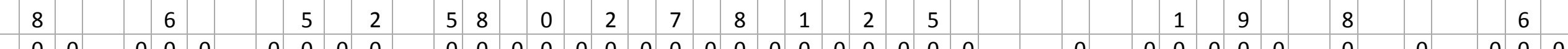

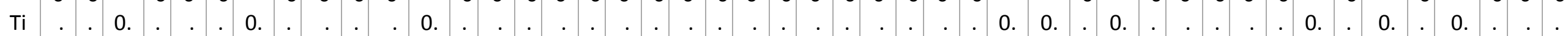

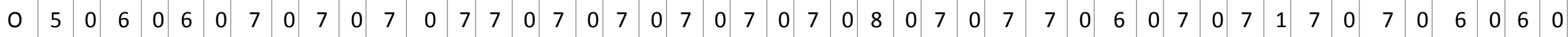
$\begin{array}{llllllllllllllllllllllllllllllllllllllllllllllllllllllll}2 & 5 & 3 & 1 & 1 & 3 & 3 & 0 & 3 & 0 & 4 & 0 & 2 & 3 & 8 & 2 & 8 & 2 & 8 & 4 & 3 & 2 & 6 & 0 & 2 & 0 & 3 & 2 & 7 & 1 & 0 & 7 & 1 & 9 & 3 & 7 & 2 & 0 & 0 & 0 & 5 & 2 & 5 & 0 & 5 & 9 & 4\end{array}$

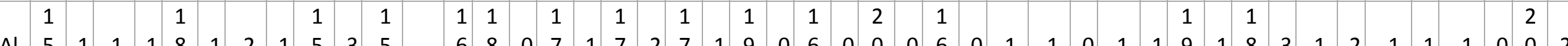
\begin{tabular}{lllllllllllllllllllllllllllllllllllllllllllllllllll}
2 & 5 & 1 & 1 & 1 & 8 & 1 & 2 & 1 & 5 & 3 & 5 & & 6 & 8 & 0 & 7 & 1 & 7 & 2 & 7 & 1 & 9 & 0 & 6 & 0 & 0 & 0 & 6 & 0 & 1 & 1 & 0 & 1 & 1 & 9 & 1 & 8 & 3 & 1 & 2 & 1 & 1 & 1 & 0 & 0 & 2 \\
\hline
\end{tabular} \begin{tabular}{lllllllllllllllllllllllllllllllllllllllllllllllllllll|l|l|l}
0 & 7 & 6 & 8 & 6 & 4 & 0 & 3 & 5 & 3 & 5 & 8 & 8 & 9 & 4 & 3 & 6 & 3 & 7 & 1 & 9 & 0 & 8 & 5 & 9 & 1 & 2 & 9 & 9 & 2 & 8 & 7 & 5 & 4 & 6 & 2 & 5 & 7 & 9 & 8 & 4 & 6 & 9 & 8 & 7 & 1 & 6
\end{tabular} $\begin{array}{lllllllllllllllllllllllllllllllllllllllllllllllllllllll}3 & 9 & 3 & 8 & 1 & 4 & 3 & 0 & 1 & 1 & 9 & 0 & 1 & 8 & 3 & 9 & 8 & 2 & 4 & 9 & 1 & 0 & 9 & 2 & 4 & 2 & 6 & 0 & 5 & 8 & 6 & 8 & 6 & 5 & 4 & 2 & 9 & 3 & 6 & 5 & 1 & 9 & 9 & 8 & 6 & 5 & 2\end{array}$ $\mathrm{F}$

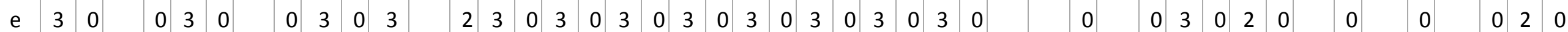

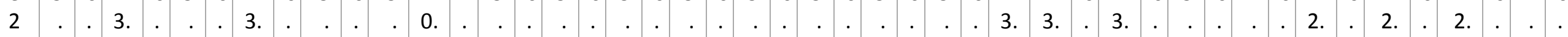
$\begin{array}{llllllllllllllllllllllllllllllllllllllllllllllllllllll}0 & 2 & 2 & 2 & 1 & 3 & 0 & 6 & 2 & 2 & 2 & 0 & 0 & 9 & 4 & 1 & 4 & 2 & 2 & 2 & 1 & 1 & 2 & 1 & 2 & 0 & 4 & 1 & 2 & 0 & 1 & 2 & 0 & 0 & 0 & 2 & 0 & 9 & 1 & 9 & 1 & 8 & 0 & 7 & 1 & 8 & 1\end{array}$

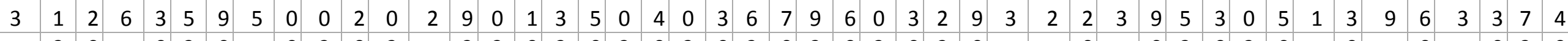

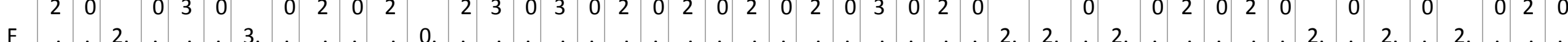

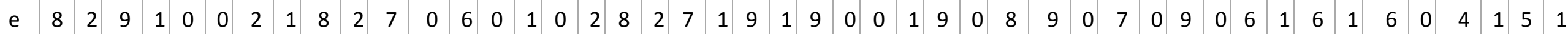
$\begin{array}{lllllllllllllllllllllllllllllllllllllllllllllllllllllllllll}0 & 9 & 0 & 3 & 2 & 1 & 8 & 8 & 8 & 8 & 0 & 0 & 2 & 9 & 6 & 0 & 8 & 3 & 8 & 2 & 8 & 2 & 3 & 6 & 6 & 5 & 5 & 1 & 0 & 8 & 1 & 0 & 2 & 2 & 8 & 2 & 3 & 1 & 3 & 2 & 1 & 0 & 5 & 6 & 2 & 8 & 2\end{array}$

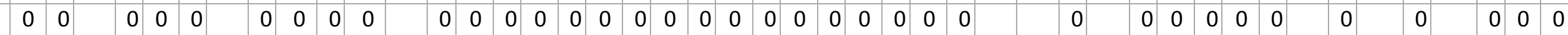

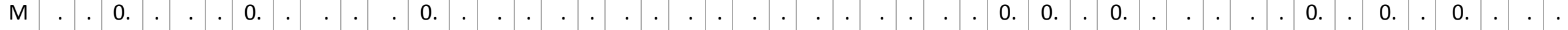
$\begin{array}{lllllllllllllllllllllllllllllllllllllllllllllllllllll}\mathrm{n} & 1 & 0 & 1 & 0 & 1 & 0 & 1 & 0 & 1 & 0 & 1 & 0 & 1 & 1 & 0 & 1 & 0 & 1 & 0 & 1 & 0 & 1 & 0 & 1 & 0 & 1 & 0 & 1 & 0 & 1 & 1 & 0 & 1 & 0 & 1 & 0 & 1 & 0 & 1 & 0 & 1 & 0 & 1 & 0 & 1 & 0\end{array}$

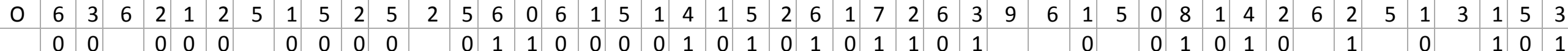

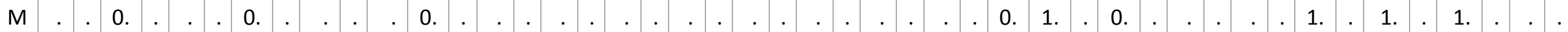
$\begin{array}{lllllllllllllllllllllllllllllllllllllllllllllllllllll}\mathrm{g} & 5 & 9 & 0 & 0 & 8 & 9 & 9 & 8 & 9 & 8 & 6 & 0 & 0 & 1 & 5 & 0 & 0 & 5 & 8 & 2 & 1 & 4 & 4 & 8 & 1 & 5 & 3 & 8 & 2 & 0 & 0 & 9 & 3 & 6 & 4 & 6 & 8 & 5 & 5 & 5 & 3 & 2 & 8 & 0 & 8 & 5\end{array}$

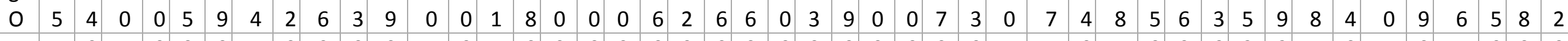

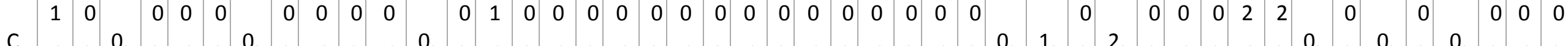
\begin{tabular}{llllllllllllllllllllllllllllllllllllllllllllllllll|l|l|l|l|l}
$\mathrm{a}$ & 4 & 5 & 9 & 0 & 7 & 0 & 7 & 0 & 6 & 0 & 6 & 0 & 7 & 0 & 0 & 7 & 0 & 7 & 1 & 7 & 0 & 8 & 0 & 8 & 0 & 8 & 0 & 9 & 1 & 6 & 0 & 1 & 9 & 2 & 7 & 0 & 4 & 9 & 7 & 0 & 6 & 1 & 6 & 0 & 4 & 0
\end{tabular} $\begin{array}{llllllllllllllllllllllllllllllllllllllllllllllllllllllll}0 & 9 & 3 & 1 & 6 & 7 & 2 & 8 & 3 & 0 & 2 & 3 & 1 & 0 & 9 & 7 & 6 & 3 & 1 & 0 & 7 & 5 & 4 & 1 & 3 & 6 & 0 & 8 & 7 & 4 & 2 & 4 & 1 & 4 & 6 & 0 & 9 & 5 & 6 & 5 & 3 & 6 & 0 & 2 & 7 & 8 & 8\end{array}$

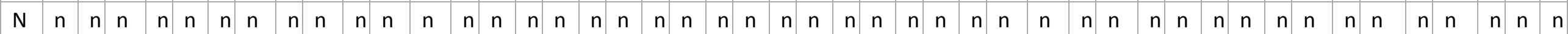


a $\mid \begin{aligned} & d \\ & \text { d }\end{aligned}$ 2

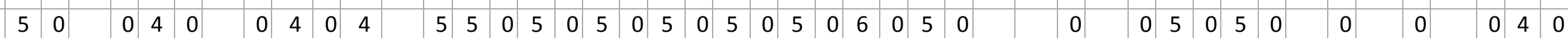

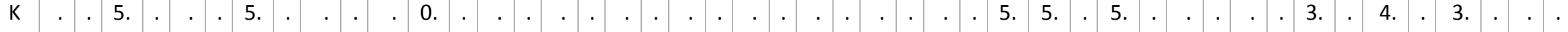
$\begin{array}{lllllllllllllllllllllllllllllllllllllllllllllllllllll}2 & 2 & 6 & 5 & 1 & 4 & 2 & 7 & 0 & 7 & 5 & 8 & 0 & 2 & 6 & 0 & 7 & 0 & 6 & 3 & 5 & 0 & 6 & 1 & 4 & 0 & 1 & 1 & 4 & 5 & 4 & 5 & 1 & 0 & 1 & 9 & 0 & 2 & 9 & 3 & 1 & 8 & 5 & 8 & 4 & 8 & 3\end{array}$

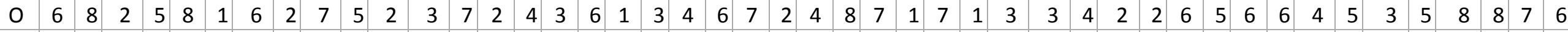

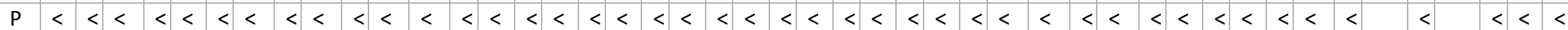

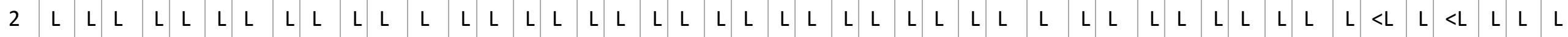
$\begin{array}{lllllllllllllllllllllllllllllllllllllllllllllllllllllllllll}\mathrm{O} & \mathrm{O} & \mathrm{O} & \mathrm{O} & \mathrm{O} & \mathrm{O} & \mathrm{O} & \mathrm{O} & \mathrm{O} & \mathrm{O} & \mathrm{O} & \mathrm{O} & \mathrm{O} & \mathrm{O} & \mathrm{O} & \mathrm{O} & \mathrm{O} & \mathrm{O} & \mathrm{O} & \mathrm{O} & \mathrm{O} & \mathrm{O} & \mathrm{O} & \mathrm{O} & \mathrm{O} & \mathrm{O} & \mathrm{O} & \mathrm{O} & \mathrm{O} & \mathrm{O} & \mathrm{O} & \mathrm{O} & \mathrm{O} & \mathrm{O} & \mathrm{O} & \mathrm{O} & \mathrm{O} & \mathrm{O} & \mathrm{O} & \mathrm{O} & \mathrm{O} & \mathrm{O} & \mathrm{O} & \mathrm{O} & \mathrm{O} & \mathrm{O} & \mathrm{O} \\ \mathrm{5} & \mathrm{D} & \mathrm{D} & \mathrm{D} & \mathrm{D} & \mathrm{D} & \mathrm{D} & \mathrm{D} & \mathrm{D} & \mathrm{D} & \mathrm{D} & \mathrm{D} & \mathrm{D} & \mathrm{D} & \mathrm{D} & \mathrm{D} & \mathrm{D} & \mathrm{D} & \mathrm{D} & \mathrm{D} & \mathrm{D} & \mathrm{D} & \mathrm{D} & \mathrm{D} & \mathrm{D} & \mathrm{D} & \mathrm{D} & \mathrm{D} & \mathrm{D} & \mathrm{D} & \mathrm{D} & \mathrm{D} & \mathrm{D} & \mathrm{D} & \mathrm{D} & \mathrm{D} & \mathrm{D} & \mathrm{D} & \mathrm{D} & \mathrm{D} & \mathrm{D} & \mathrm{D} & \mathrm{D} & \mathrm{D} & \mathrm{D} & \mathrm{D} & \mathrm{D} & & & \end{array}$ 3 7 5

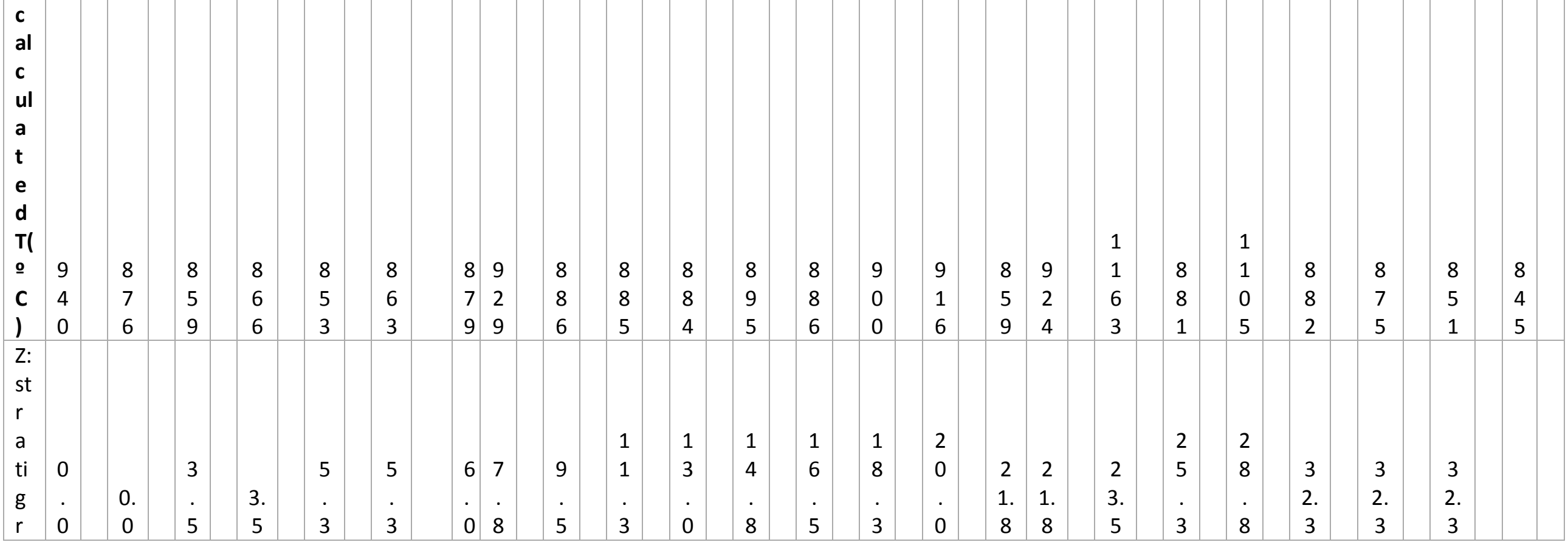




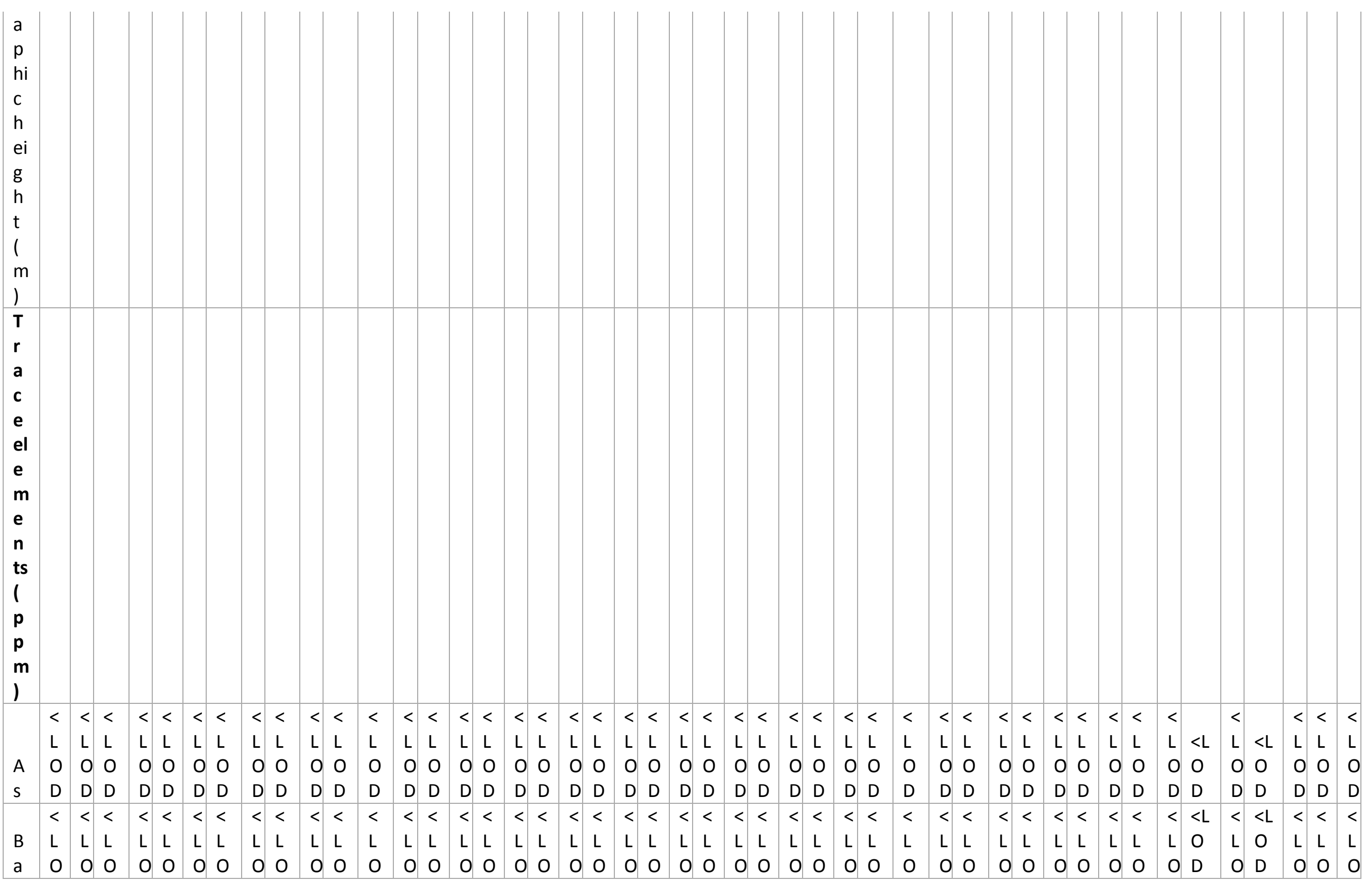




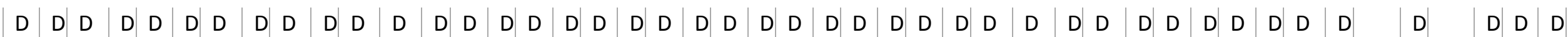

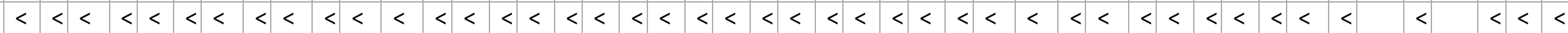

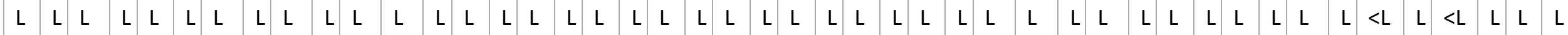

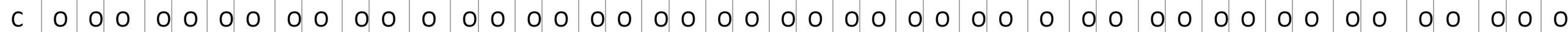

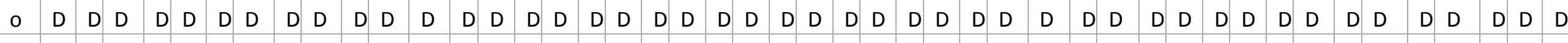

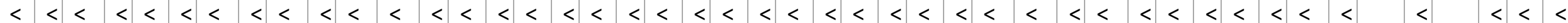

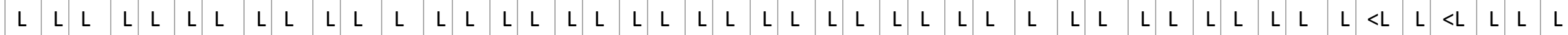

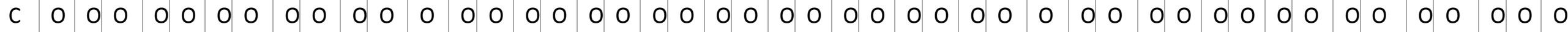

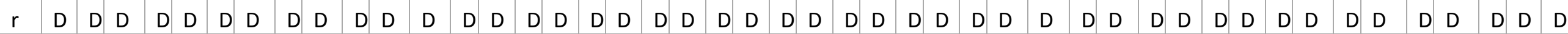

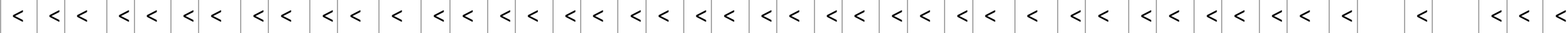

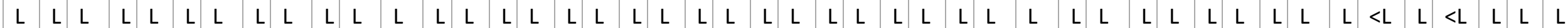

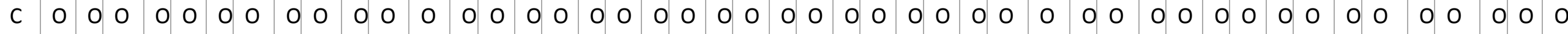

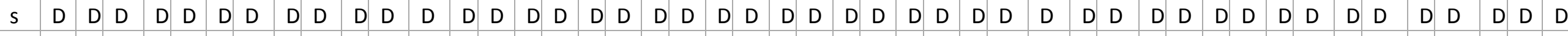

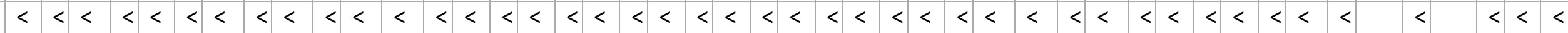

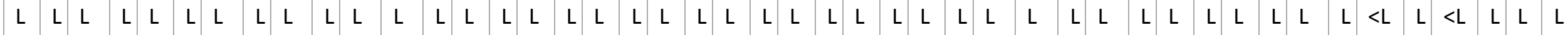
C $\quad$ O

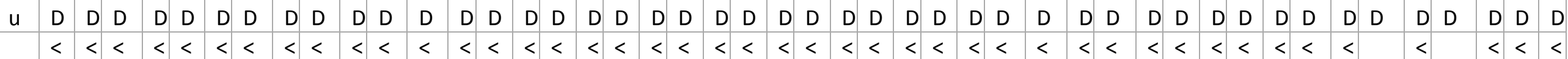

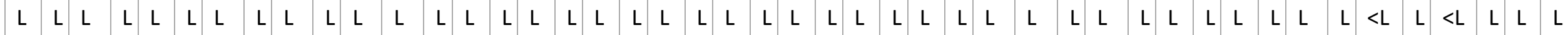

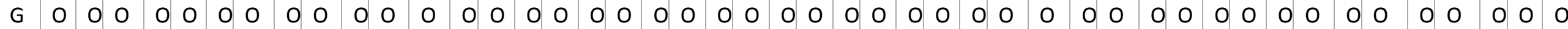
\begin{tabular}{llllllllllllllllllllllllllllllllllllllllllllllllllllllllllll}
$\mathrm{a}$ & $\mathrm{D}$ & $\mathrm{D}$ & $\mathrm{D}$ & $\mathrm{D}$ & $\mathrm{D}$ & $\mathrm{D}$ & $\mathrm{D}$ & $\mathrm{D}$ & $\mathrm{D}$ & $\mathrm{D}$ & $\mathrm{D}$ & $\mathrm{D}$ & $\mathrm{D}$ & $\mathrm{D}$ & $\mathrm{D}$ & $\mathrm{D}$ & $\mathrm{D}$ & $\mathrm{D}$ & $\mathrm{D}$ & $\mathrm{D}$ & $\mathrm{D}$ & $\mathrm{D}$ & $\mathrm{D}$ & $\mathrm{D}$ & $\mathrm{D}$ & $\mathrm{D}$ & $\mathrm{D}$ & $\mathrm{D}$ & $\mathrm{D}$ & $\mathrm{D}$ & $\mathrm{D}$ & $\mathrm{D}$ & $\mathrm{D}$ & $\mathrm{D}$ & $\mathrm{D}$ & $\mathrm{D}$ & $\mathrm{D}$ & $\mathrm{D}$ & $\mathrm{D}$ & $\mathrm{D}$ & $\mathrm{D}$ & $\mathrm{D}$ & $\mathrm{D}$ & $\mathrm{D}$ & $\mathrm{D}$ & $\mathrm{D}$ \\
\hline
\end{tabular}

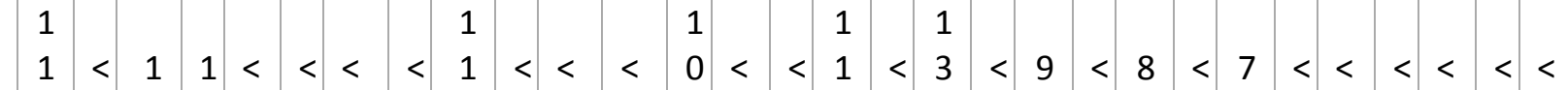

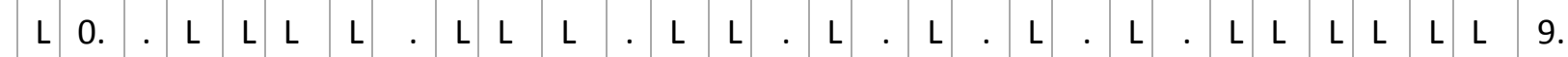
M $4 \begin{array}{lllllllllllllllllllllllllllllllll} & 0 & 8 & 0 & 0 & 0 & 0 & 0 & 8 & 0 & 0 & 0 & 3 & 0 & 0 & 9 & 0 & 0 & 0 & 3 & 0 & 8 & 0 & 4 & 0 & 0 & 0 & 0 & 0 & 0 & 1\end{array}$

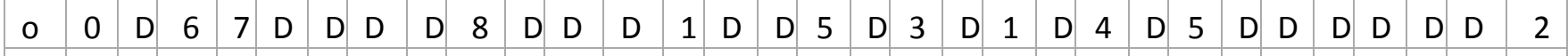

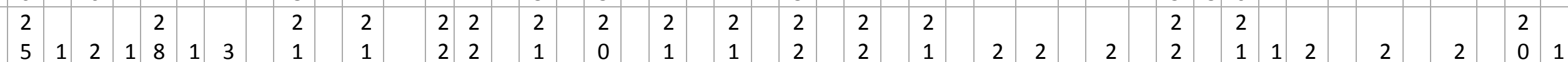

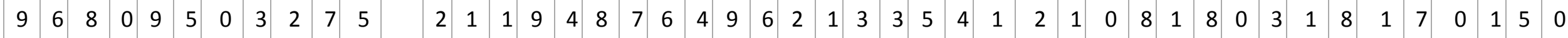

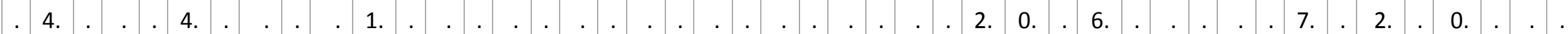

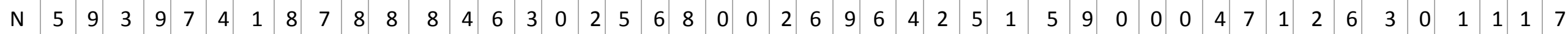
\begin{tabular}{lllllllllllllllllllllllll|l|l|l|l|l|l|l|l|l|l|l|l|l|l|l|l|l|l|l|l|l|l|l|l|l|l}
$\mathrm{b}$ & 9 & 5 & 8 & 7 & 8 & 0 & 1 & 8 & 9 & 3 & 5 & 9 & 0 & 2 & 3 & 9 & 8 & 3 & 4 & 5 & 9 & 4 & 8 & 8 & 7 & 1 & 3 & 3 & 8 & 3 & 1 & 9 & 3 & 2 & 5 & 4 & 3 & 9 & 9 & 8 & 4 & 6 & 2 & 1 & 3 & 2
\end{tabular}

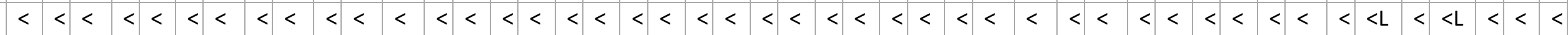
$\begin{array}{llllllllllllllllllllllllllllllllllllllllllllllllllllll}\text { N } & \text { L } & \text { L } & \text { L } & \text { L } & \text { L } & \text { L } & \text { L } & \text { L } & \text { L } & \text { L } & \text { L } & \text { L } & \text { L } & \text { L } & \text { L } & \text { L } & \text { L } & \text { L } & \text { L } & \text { L } & \text { L } & \text { L } & \text { L } & \text { L } & \text { L } & \text { L } & \text { L } & \text { L } & \text { L } & \text { L } & \text { L } & \text { L } & \text { L } & \text { L } & \text { L } & \text { L } & \text { L } & \text { L } & \text { L } & \text { L } & \text { O } & \text { L } & \text { O } & \text { L } & \text { L } & \text { L }\end{array}$

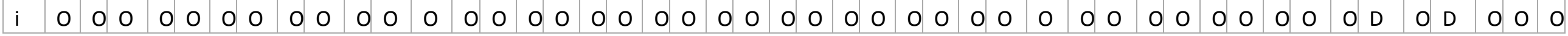




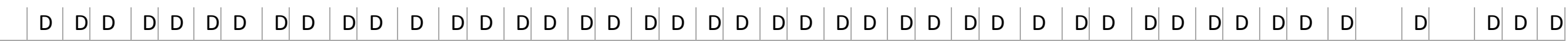

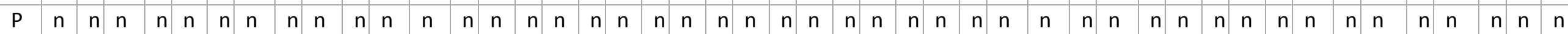

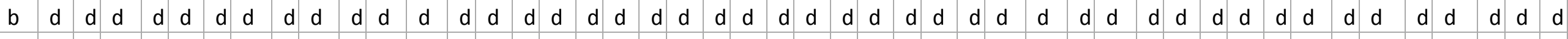

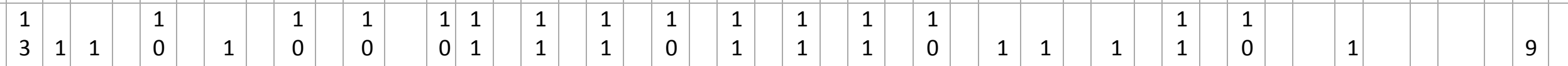

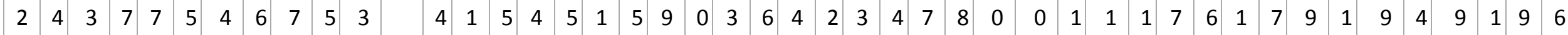

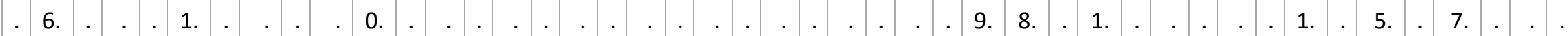
\begin{tabular}{llllllllllllllllllllllllllllllllllllllllllllllllll|l|l|l|l}
$\mathrm{R}$ & 3 & 1 & 6 & 4 & 5 & 4 & 9 & 1 & 0 & 4 & 6 & 0 & 6 & 0 & 2 & 3 & 9 & 4 & 4 & 8 & 9 & 6 & 9 & 1 & 9 & 3 & 6 & 8 & 4 & 6 & 9 & 0 & 3 & 1 & 5 & 1 & 0 & 8 & 8 & 5 & 2 & 2 & 0 & 5 & 8 & 0
\end{tabular} \begin{tabular}{llllllllllllllllllllllllllllllllllllllllllllllllll|l|l|l|l|l}
$\mathrm{b}$ & 8 & 7 & 8 & 0 & 9 & 8 & 8 & 8 & 0 & 4 & 7 & 9 & 4 & 0 & 0 & 0 & 7 & 3 & 7 & 6 & 5 & 6 & 9 & 8 & 6 & 6 & 1 & 2 & 4 & 2 & 8 & 8 & 5 & 5 & 1 & 8 & 5 & 4 & 3 & 3 & 7 & 7 & 0 & 3 & 7 & 4
\end{tabular}

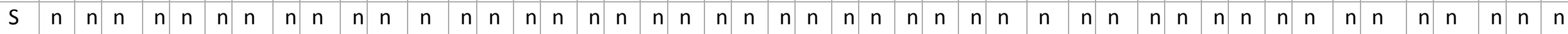

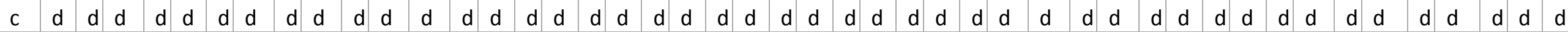

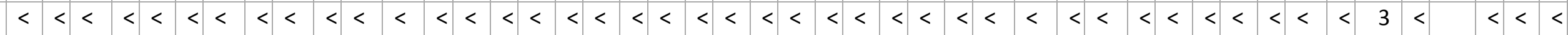

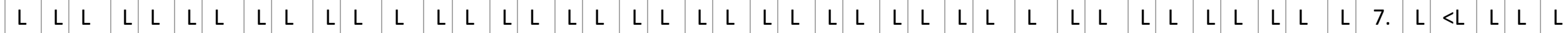

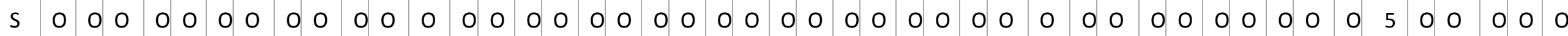

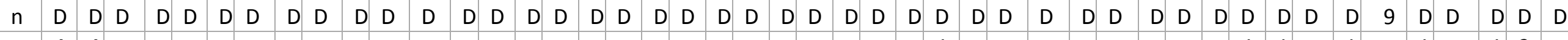

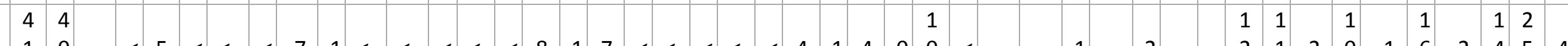

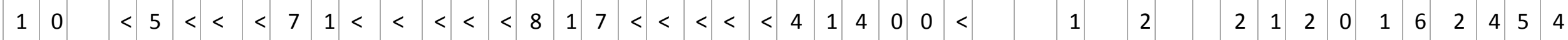

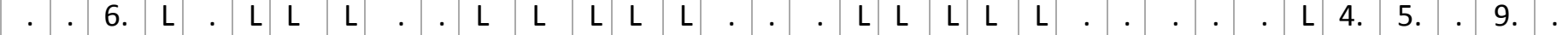

$\begin{array}{lllllllllllllllllllllllllllllllllllllllll}0 & 0 & 4 & 0 & 4 & 0 & 0 & 0 & 3 & 4 & 0 & 0 & 0 & 0 & 0 & 0 & 9 & 0 & 0 & 0 & 0 & 0 & 0 & 6 & 2 & 3 & 1 & 4 & 0 & 5 & 1 & 1 & 5 & 0\end{array}$

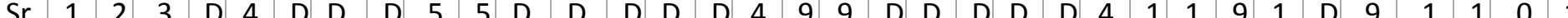
$\begin{array}{lllllllllll}9 & 4 & 8 & 5 & 9 & 8 & 3 & 8 & 1 & 2\end{array}$ \begin{tabular}{lllllllllllllll|l|l|l|l|l|l|l|l|l|l|l|l|l|l|l|l|l|l|l|l|l|l|l|l|l|l|l|l|l|l|l|l}
6 & 3 & 4 & 4 & 4 & 4 & 4 & 4 & 8 & 3 & 1 & $<$ & 5 & 3 & 4 & 2 & 9 & 5 & 2 & 6 & 0 & 8 & 5 & 0 & 3 & 8 & 3 & 2 & 5 & 2 & 2 & 4 & 3 & 2 & 2 & 2 & 8 & 3 & 3 & 2 & 3 & 8 & 2 & 1 & 7 & 1
\end{tabular}

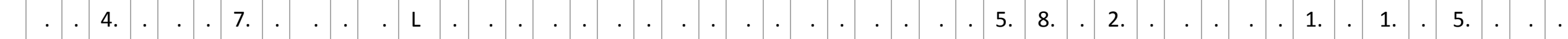
$\begin{array}{llllllllllllllllllllllllllllllllllllllllllllllllllllllll}\mathrm{T} & 4 & 0 & 6 & 2 & 8 & 0 & 8 & 8 & 2 & 8 & 4 & 0 & 7 & 6 & 8 & 3 & 6 & 9 & 7 & 5 & 7 & 9 & 7 & 3 & 9 & 0 & 6 & 7 & 7 & 8 & 7 & 3 & 9 & 8 & 5 & 6 & 9 & 3 & 3 & 8 & 6 & 3 & 5 & 7 & 3 & 5\end{array}$

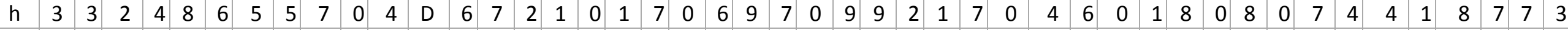

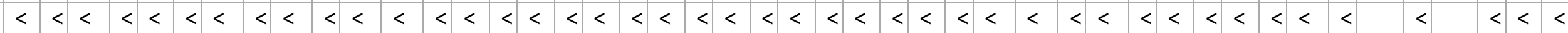

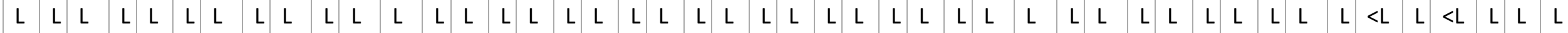

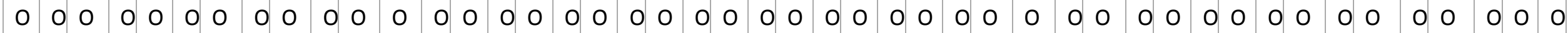

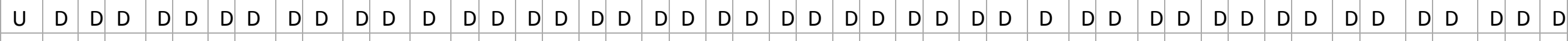

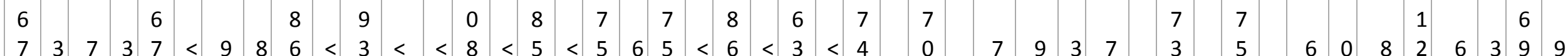

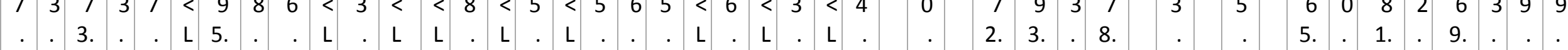

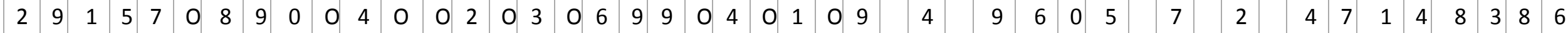

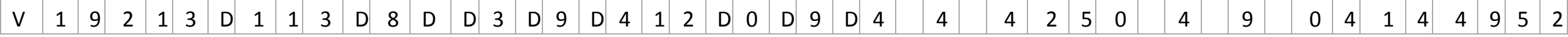




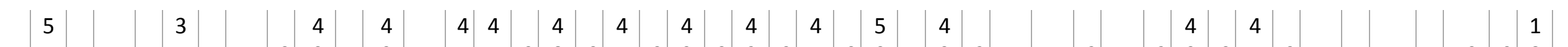

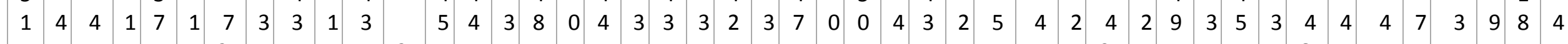

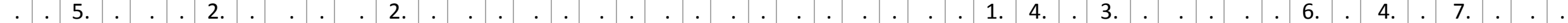

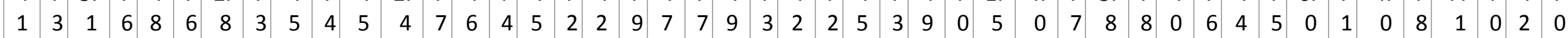

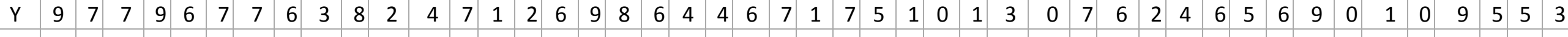

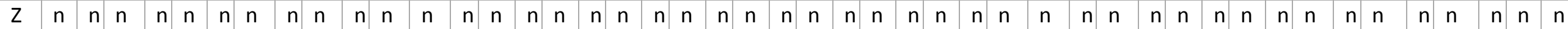

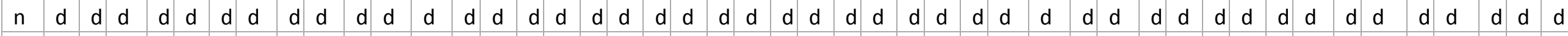

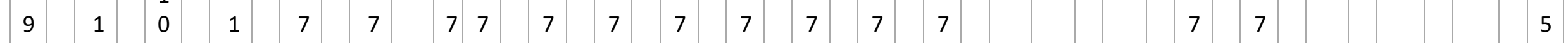

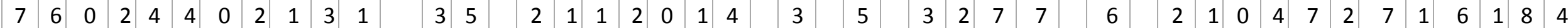

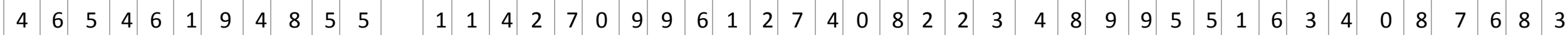

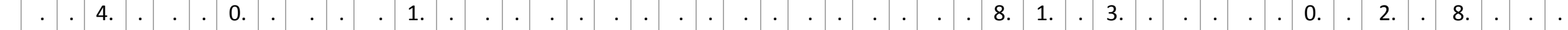

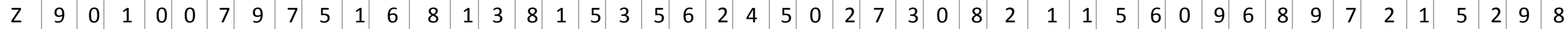

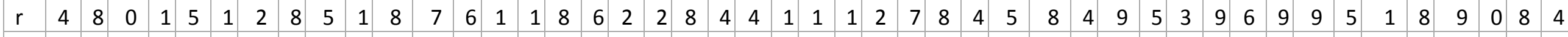

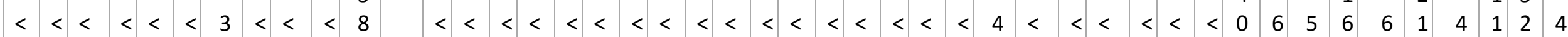

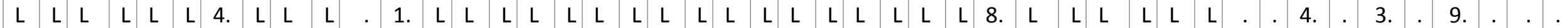

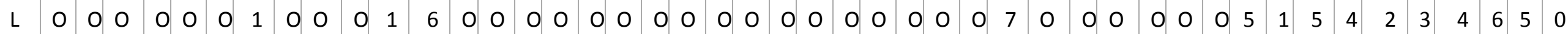

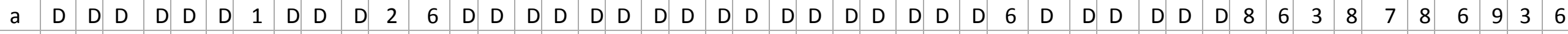

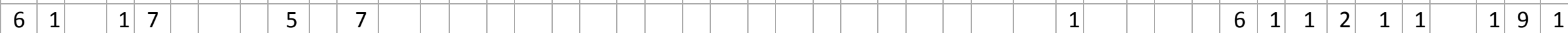

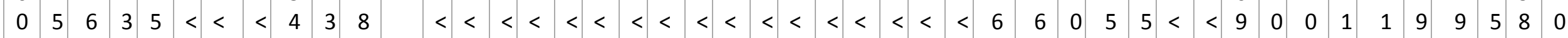

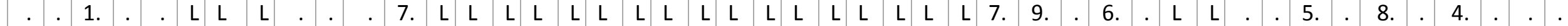

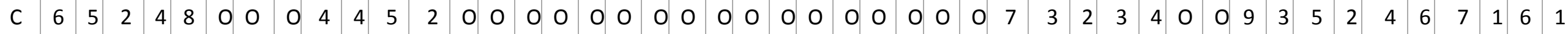

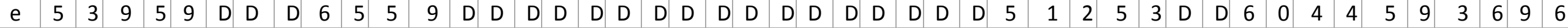

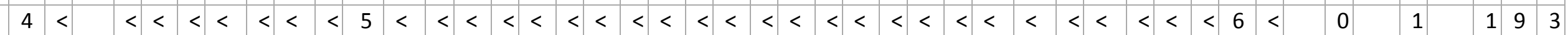

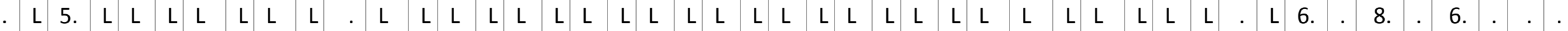

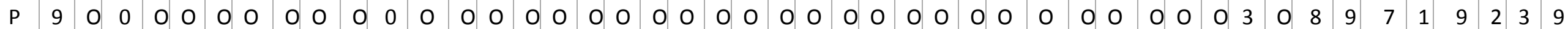

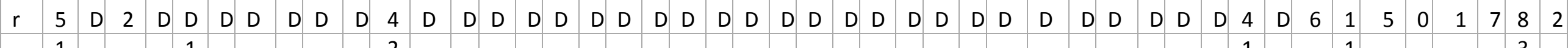

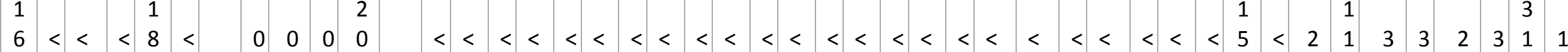

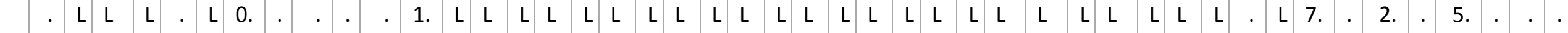

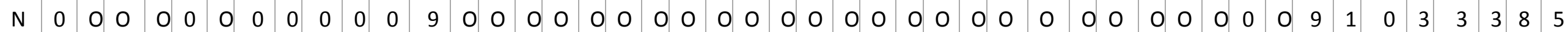

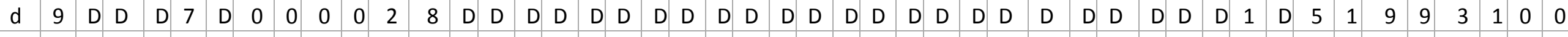

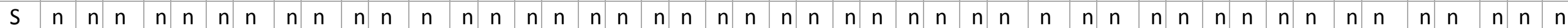

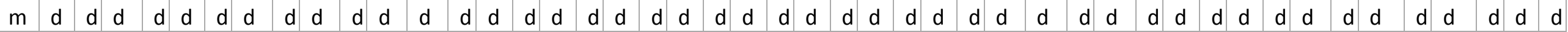




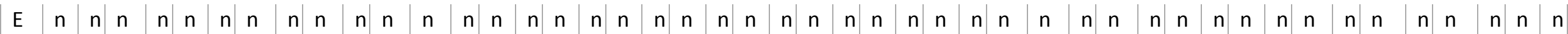

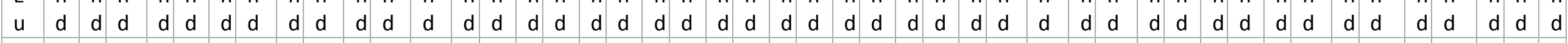

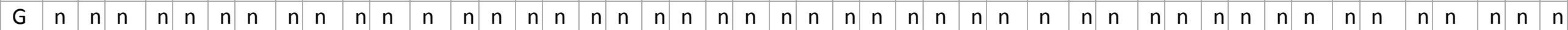

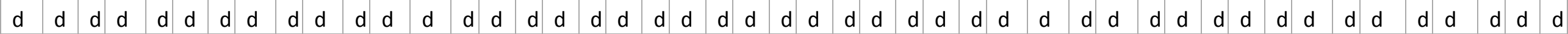

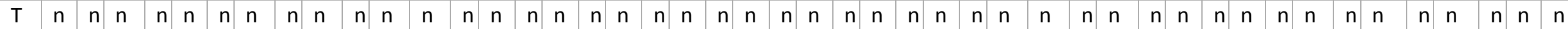

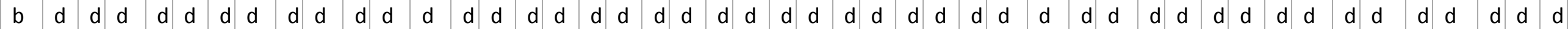

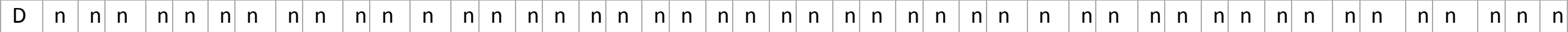

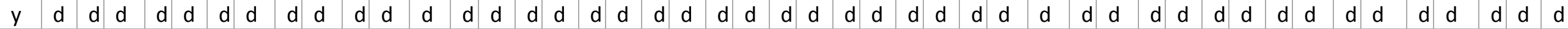

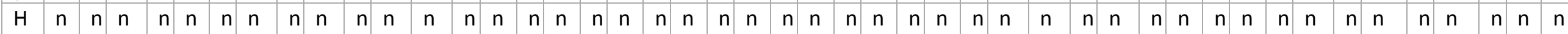

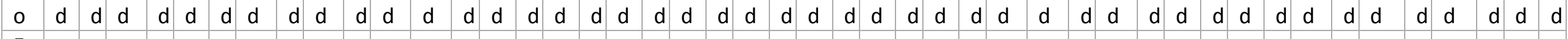

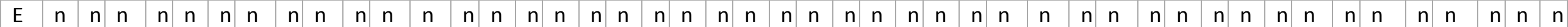

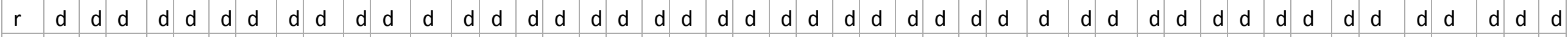

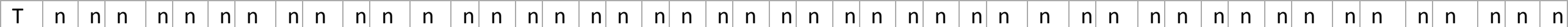

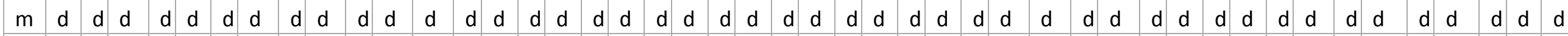

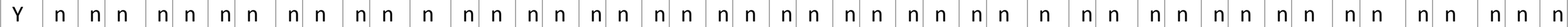

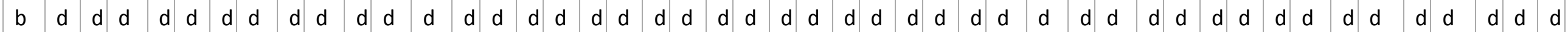

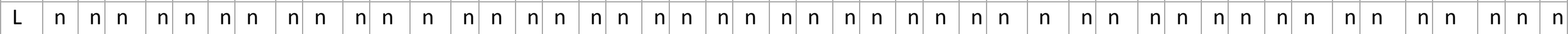

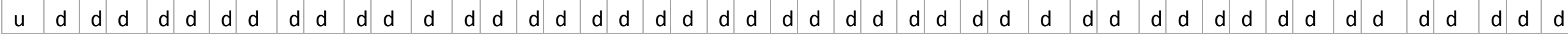
\begin{tabular}{|l|l|l|l|l|l|l|l|l|l|l|l|l|l|l|l|l|}
1 & & & & & & & & & & & 1 & & & & 1 & \\
\hline
\end{tabular}

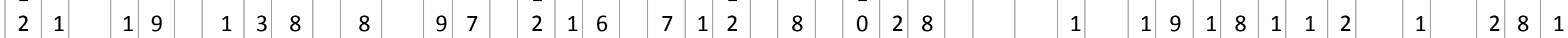

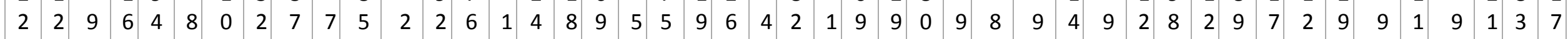

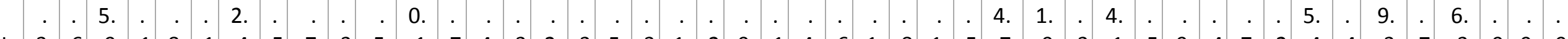

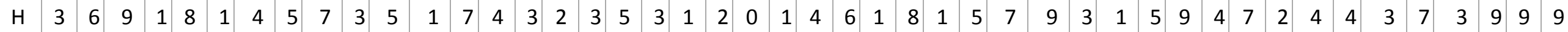

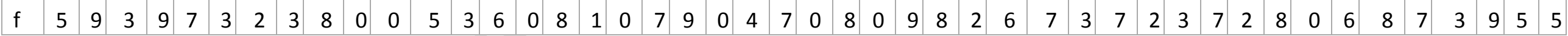

\begin{tabular}{|c|c|c|c|c|c|c|c|c|c|c|c|c|c|c|c|c|c|c|}
\hline \multirow[t]{4}{*}{$\begin{array}{l}\text { Laboratory } \\
\text { XRF }\end{array}$} & EP-S-3Aa & $\begin{array}{l}\text { EP-S- } \\
3 \mathrm{Ba}\end{array}$ & $\begin{array}{l}\text { EP-S- } \\
3 \mathrm{Ca}\end{array}$ & $\begin{array}{l}\text { EP-S- } \\
4 A B\end{array}$ & $\begin{array}{l}E P-S- \\
4 A B 1\end{array}$ & $\begin{array}{l}\text { EP-S- } \\
4 B A\end{array}$ & $\begin{array}{l}\text { EP-S- } \\
4 C A\end{array}$ & $\begin{array}{l}\text { EP-S- } \\
4 D A\end{array}$ & $\begin{array}{l}\text { EP-S- } \\
4 E A\end{array}$ & $\begin{array}{l}\text { EP-S- } \\
4 F A\end{array}$ & $\begin{array}{l}\text { EP-S- } \\
4 G A\end{array}$ & $\begin{array}{l}\text { EP-S- } \\
4 \mathrm{HA}\end{array}$ & $\begin{array}{l}\text { EP-S- } \\
4 \mathrm{HB}\end{array}$ & $\begin{array}{l}\text { EP-S- } \\
4 \mathrm{HC}\end{array}$ & $\begin{array}{l}\text { EP-S- } \\
4 I C\end{array}$ & $\begin{array}{l}\text { EP-S- } \\
4 J P\end{array}$ & $\begin{array}{l}\text { EP-S- } \\
4 J M\end{array}$ & $\begin{array}{l}\text { EP-S- } \\
5 \mathrm{M}\end{array}$ \\
\hline & phonolite & $\begin{array}{l}\text { pho- } \\
\text { no- } \\
\text { lite }\end{array}$ & $\begin{array}{l}\text { pho- } \\
\text { no- } \\
\text { lite }\end{array}$ & $\begin{array}{l}\text { pho- } \\
\text { no- } \\
\text { lite }\end{array}$ & $\begin{array}{l}\text { pho- } \\
\text { nolite }\end{array}$ & $\begin{array}{l}\text { pho- } \\
\text { no- } \\
\text { lite }\end{array}$ & $\begin{array}{l}\text { pho- } \\
\text { no- } \\
\text { lite }\end{array}$ & $\begin{array}{l}\text { pho- } \\
\text { no- } \\
\text { lite }\end{array}$ & $\begin{array}{l}\text { pho- } \\
\text { no- } \\
\text { lite }\end{array}$ & $\begin{array}{l}\text { pho- } \\
\text { no- } \\
\text { lite }\end{array}$ & $\begin{array}{l}\text { pho- } \\
\text { no- } \\
\text { lite }\end{array}$ & $\begin{array}{l}\text { pho- } \\
\text { no- } \\
\text { lite }\end{array}$ & $\begin{array}{l}\text { pho- } \\
\text { no- } \\
\text { lite }\end{array}$ & $\begin{array}{l}\text { pho- } \\
\text { no- } \\
\text { lite }\end{array}$ & $\begin{array}{l}\text { pho- } \\
\text { no- } \\
\text { lite }\end{array}$ & $\begin{array}{l}\text { pho- } \\
\text { no- } \\
\text { lite }\end{array}$ & $\begin{array}{l}\text { pho- } \\
\text { no- } \\
\text { lite }\end{array}$ & $\begin{array}{l}\text { teph } \\
\text { ri-ph }\end{array}$ \\
\hline & $\begin{array}{l}\text { Upper El } \\
\text { Palomar }\end{array}$ & & & & & & & & & & & & & & & & & \\
\hline & $\begin{array}{l}\text { Upper } \\
\text { Group }\end{array}$ & & & & & & & & & & & & & & & & & \\
\hline
\end{tabular}




\begin{tabular}{|c|c|c|c|c|c|c|c|c|c|c|c|c|c|c|c|c|c|c|}
\hline $\mathrm{wt} \%$ & $\begin{array}{l}\text { Guajara } \\
\text { Fm }\end{array}$ & & & & & & & & & & & & & & & & & \\
\hline & & 58.6 & 59.7 & 60.5 & & 58.9 & 59.1 & 59.0 & 59.9 & 59.6 & 59.1 & 58.8 & 59.8 & 58.3 & 61.2 & 59.0 & 58.7 & 58.5 \\
\hline $\mathrm{SiO} 2$ & 58.77 & 5 & 3 & 2 & 59.87 & 1 & 0 & 2 & 7 & 2 & 3 & 0 & 5 & 3 & 3 & 1 & 9 & 3 \\
\hline \multirow[t]{2}{*}{ TiO2 } & 0.65 & 0.61 & 0.66 & 0.77 & 0.77 & 0.77 & 0.77 & 0.79 & 0.77 & 0.78 & 0.79 & 0.79 & 0.78 & 0.76 & 0.76 & 0.72 & 0.76 & 1.31 \\
\hline & & 18.1 & 18.2 & 18.6 & & 18.4 & 18.0 & 18.6 & 18.8 & 18.3 & 18.9 & 18.6 & 19.0 & 19.0 & 19.6 & 18.9 & 18.2 & 19.5 \\
\hline $\mathrm{Al} 2 \mathrm{O} 3$ & 18.31 & 4 & 0 & 4 & 18.60 & 9 & 7 & 6 & 7 & 2 & 5 & 5 & 5 & 2 & 6 & 0 & 0 & 3 \\
\hline $\mathrm{Fe} 2 \mathrm{O} 3$ & 3.21 & 3.41 & 3.50 & 3.17 & 3.19 & 3.13 & 3.13 & 3.14 & 3.17 & 3.44 & 3.22 & 3.22 & 3.26 & 3.24 & 3.33 & 3.16 & 3.09 & 4.80 \\
\hline $\mathrm{FeO}$ & 2.89 & 3.07 & 3.15 & 2.85 & 2.87 & 2.81 & 2.81 & 2.82 & 2.85 & 3.09 & 2.89 & 2.89 & 2.93 & 2.91 & 2.99 & 2.84 & 2.78 & 4.32 \\
\hline $\mathrm{MnO}$ & 0.11 & 0.11 & 0.21 & 0.18 & 0.20 & 0.20 & 0.20 & 0.20 & 0.19 & 0.19 & 0.19 & 0.21 & 0.21 & 0.21 & 0.20 & 0.16 & 0.11 & 0.21 \\
\hline $\mathrm{MgO}$ & 0.25 & 0.24 & 0.29 & 0.33 & 0.26 & 0.34 & 0.37 & 0.37 & 0.31 & 0.32 & 0.31 & 0.35 & 0.38 & 0.32 & 0.25 & 0.30 & 0.28 & 0.86 \\
\hline $\mathrm{CaO}$ & 0.59 & 0.82 & 0.67 & 0.81 & 0.74 & 0.75 & 0.78 & 0.82 & 0.75 & 0.76 & 0.74 & 0.80 & 0.78 & 0.69 & 0.79 & 0.85 & 0.65 & 3.34 \\
\hline $\mathrm{Na} 2 \mathrm{O}$ & 5.85 & 5.34 & 5.59 & 6.70 & 7.90 & 7.34 & 7.24 & 7.07 & 6.77 & 7.04 & 7.25 & 6.85 & 7.55 & 7.32 & 6.53 & 7.43 & 7.49 & 5.90 \\
\hline $\mathrm{K} 2 \mathrm{O}$ & 6.84 & 6.64 & 6.18 & 5.40 & 6.11 & 5.87 & 6.22 & 5.96 & 5.67 & 5.72 & 5.85 & 6.53 & 5.84 & 6.46 & 5.18 & 6.37 & 7.01 & 4.44 \\
\hline P2O5 & 0.05 & 0.04 & 0.05 & 0.07 & 0.07 & 0.07 & 0.08 & 0.08 & 0.08 & 0.07 & 0.08 & 0.07 & 0.07 & 0.07 & 0.06 & 0.06 & 0.07 & 0.21 \\
\hline LOI & 4.78 & 5.78 & 4.49 & 3.10 & 2.48 & 3.86 & 3.89 & 4.09 & 3.72 & 3.87 & 3.66 & 3.91 & 2.41 & 3.31 & 1.75 & 3.08 & 3.15 & 0.95 \\
\hline & & $\begin{array}{r}99.8 \\
1\end{array}$ & $\begin{array}{r}99.5 \\
7\end{array}$ & $\begin{array}{r}99.6 \\
9\end{array}$ & $\begin{array}{r}100.2 \\
0\end{array}$ & $\begin{array}{r}99.7 \\
3\end{array}$ & $\begin{array}{r}99.8 \\
3\end{array}$ & $\begin{array}{r}100 . \\
18\end{array}$ & $\begin{array}{r}100 . \\
27\end{array}$ & $\begin{array}{r}100 . \\
14\end{array}$ & $\begin{array}{r}100 . \\
17\end{array}$ & $\begin{array}{r}100 . \\
18\end{array}$ & $\begin{array}{r}100 . \\
19\end{array}$ & $\begin{array}{r}99.7 \\
4\end{array}$ & $\begin{array}{r}99.7 \\
2\end{array}$ & $\begin{array}{r}100 . \\
04\end{array}$ & $\begin{array}{r}99.6 \\
0\end{array}$ & $\begin{array}{r}100 . \\
09\end{array}$ \\
\hline \multicolumn{19}{|c|}{$\begin{array}{l}\text { TOTAL } \\
\text { Trace ele- } \\
\text { ments (ppm) }\end{array}$} \\
\hline \multirow[t]{2}{*}{ As } & $<1$ & $<1$ & 4.00 & 4.00 & 4.00 & 5.00 & 4.00 & 5.00 & 4.00 & 4.00 & 5.00 & 4.00 & 4.00 & 4.00 & 4.00 & $<1$ & $<1$ & 1.00 \\
\hline & & 33.0 & 12.0 & 47.0 & & 46.0 & 58.0 & 55.0 & 55.0 & 52.0 & 54.0 & 49.0 & 74.0 & 34.0 & 142. & 78.0 & 107. & 923. \\
\hline \multirow[t]{2}{*}{$\mathrm{Ba}$} & 52.00 & 0 & 0 & 0 & 45.00 & 0 & 0 & 0 & 0 & 0 & 0 & 0 & 0 & 0 & 00 & 0 & 00 & 00 \\
\hline & & & & 15.0 & & 34.0 & 27.0 & 21.0 & 95.0 & 38.0 & 38.0 & 32.0 & 33.0 & 40.0 & 22.0 & & & \\
\hline \multirow[t]{2}{*}{ Co } & - & - & 9.00 & 0 & 28.00 & 0 & 0 & 0 & 0 & 0 & 0 & 0 & 0 & 0 & 0 & - & - & \\
\hline & & & & & & 10.0 & & & & & 19.0 & & 10.0 & & 41.0 & & & 20.0 \\
\hline \multirow[t]{2}{*}{$\mathrm{Cr}$} & $<3$ & $<3$ & $<3$ & 5.00 & $<3$ & 0 & 3.00 & 3.00 & $<3$ & $<3$ & 0 & $<3$ & 0 & 4.00 & 0 & 4.00 & $<3$ & 0 \\
\hline & & & & & & & & & & & & 11.0 & 10.0 & 10.0 & & & 15.0 & \\
\hline Cs & 9.00 & 4.00 & 6.00 & 8.00 & 7.00 & 9.00 & 9.00 & 8.00 & 2.00 & 8.00 & 4.00 & 0 & 0 & 0 & 5.00 & 3.00 & 0 & \\
\hline \multirow{3}{*}{$\mathrm{Cu}$} & & 15.0 & & & & & & & & & & & & & & 18.0 & 17.0 & \\
\hline & 18.00 & 0 & $<1$ & $<1$ & 1.00 & $<1$ & $<1$ & 3.00 & $<1$ & $<1$ & $<1$ & $<1$ & $<1$ & 1.00 & $<1$ & 0 & 0 & \\
\hline & & 36.0 & 28.0 & 25.0 & & 25.0 & 24.0 & 25.0 & 24.0 & 25.0 & 25.0 & 25.0 & 25.0 & 25.0 & 27.0 & 34.0 & 31.0 & 23.0 \\
\hline $\mathrm{Ga}$ & 35.00 & 0 & 0 & 0 & 24.00 & 0 & 0 & 0 & 0 & 0 & 0 & 0 & 0 & 0 & 0 & 0 & 0 & 0 \\
\hline
\end{tabular}




\section{Journal Pre-proof}

\begin{tabular}{|c|c|c|c|c|c|c|c|c|c|c|c|c|c|c|c|c|c|c|}
\hline Mo & - & 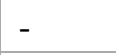 & 6.00 & 6.00 & 6.00 & 6.00 & 7.00 & 6.00 & 7.00 & 6.00 & 6.00 & 6.00 & 6.00 & 7.00 & 3.00 & - & - & \\
\hline $\mathrm{Nb}$ & 290.00 & $\begin{array}{r}287 . \\
00\end{array}$ & $\begin{array}{r}260 . \\
00\end{array}$ & $\begin{array}{r}196 . \\
00\end{array}$ & $\begin{array}{r}193.0 \\
0\end{array}$ & $\begin{array}{r}193 . \\
00\end{array}$ & $\begin{array}{r}189 . \\
00\end{array}$ & $\begin{array}{r}192 . \\
00\end{array}$ & $\begin{array}{r}191 . \\
00\end{array}$ & $\begin{array}{r}193 . \\
00\end{array}$ & $\begin{array}{r}193 . \\
00\end{array}$ & $\begin{array}{r}193 . \\
00\end{array}$ & $\begin{array}{r}200 . \\
00\end{array}$ & $\begin{array}{r}206 . \\
00\end{array}$ & $\begin{array}{r}209 . \\
00\end{array}$ & $\begin{array}{r}225 . \\
00\end{array}$ & $\begin{array}{r}218 . \\
00\end{array}$ & $\begin{array}{r}158 . \\
00\end{array}$ \\
\hline $\mathrm{Ni}$ & $<2$ & $<2$ & 5.00 & 6.00 & 4.00 & 5.00 & 6.00 & 5.00 & 6.00 & 4.00 & 5.00 & 4.00 & 4.00 & 5.00 & 5.00 & $<2$ & $<2$ & $\begin{array}{r}14.0 \\
0\end{array}$ \\
\hline $\mathrm{Pb}$ & 14.00 & 5.00 & 9.00 & $\begin{array}{r}10.0 \\
0\end{array}$ & 9.00 & 8.00 & 9.00 & 9.00 & 7.00 & 9.00 & 9.00 & $\begin{array}{r}11.0 \\
0\end{array}$ & $\begin{array}{r}12.0 \\
0\end{array}$ & 9.00 & $\begin{array}{r}14.0 \\
0\end{array}$ & $\begin{array}{r}16.0 \\
0\end{array}$ & $\begin{array}{r}12.0 \\
0\end{array}$ & $\begin{array}{r}13.0 \\
0\end{array}$ \\
\hline $\mathrm{Rb}$ & 111.00 & $\begin{array}{r}107 . \\
00\end{array}$ & $\begin{array}{r}132 . \\
00\end{array}$ & $\begin{array}{r}105 . \\
00\end{array}$ & $\begin{array}{r}102.0 \\
0 \\
\end{array}$ & $\begin{array}{r}102 . \\
00\end{array}$ & $\begin{array}{r}103 . \\
00\end{array}$ & $\begin{array}{r}105 . \\
00\end{array}$ & $\begin{array}{r}104 . \\
00 \\
\end{array}$ & $\begin{array}{r}107 . \\
00\end{array}$ & $\begin{array}{r}107 . \\
00\end{array}$ & $\begin{array}{r}104 . \\
00\end{array}$ & $\begin{array}{r}87.0 \\
0\end{array}$ & $\begin{array}{r}106 . \\
00\end{array}$ & $\begin{array}{r}64.0 \\
0 \\
\end{array}$ & $\begin{array}{r}66.0 \\
0\end{array}$ & $\begin{array}{r}87.0 \\
0 \\
\end{array}$ & $\begin{array}{r}75.0 \\
0 \\
\end{array}$ \\
\hline Sc & $<1$ & 3.00 & 2.00 & 4.00 & 1.00 & 1.00 & 1.00 & 3.00 & $<1$ & 3.00 & $<1$ & $<1$ & 3.00 & 4.00 & 2.00 & 2.00 & $<1$ & $\begin{array}{r}10.0 \\
0\end{array}$ \\
\hline Sn & - & - & 6.00 & 7.00 & 4.00 & 5.00 & 5.00 & 5.00 & $\begin{array}{r}10.0 \\
0\end{array}$ & 4.00 & 8.00 & 4.00 & $<2$ & 5.00 & 7.00 & - & - & \\
\hline Sr & .00 & $<$ & 4.00 & 2.00 & 3.00 & 3.00 & 4.00 & 5.00 & 5.00 & 6.00 & 4.00 & 6.00 & 6.00 & 5.00 & $\begin{array}{r}14.0 \\
0\end{array}$ & $\begin{array}{r}10.0 \\
0\end{array}$ & 3.00 & $\begin{array}{r}734 . \\
00\end{array}$ \\
\hline Th & 23.00 & $\begin{array}{r}25.0 \\
0\end{array}$ & $\begin{array}{r}27.0 \\
0\end{array}$ & $\begin{array}{r}18.0 \\
0\end{array}$ & 19.00 & $\begin{array}{r}19.0 \\
0\end{array}$ & $\begin{array}{r}18.0 \\
0\end{array}$ & $\begin{array}{r}17.0 \\
0\end{array}$ & $\begin{array}{r}17.0 \\
0\end{array}$ & $\begin{array}{r}19.0 \\
0\end{array}$ & $\begin{array}{r}18.0 \\
0\end{array}$ & $\begin{array}{r}18.0 \\
0\end{array}$ & $\begin{array}{r}19.0 \\
0\end{array}$ & $\begin{array}{r}18.0 \\
0\end{array}$ & $\begin{array}{r}19.0 \\
0\end{array}$ & $\begin{array}{r}14.0 \\
0\end{array}$ & $\begin{array}{r}18.0 \\
0\end{array}$ & $\begin{array}{r}18.0 \\
0\end{array}$ \\
\hline U & .00 & 3.00 & - & - & 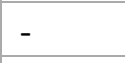 & _. & - & - & - & - & - & - & - & - & - & 4.00 & 2.00 & 2.00 \\
\hline V & 32.00 & $\begin{array}{r}28.0 \\
0\end{array}$ & $\begin{array}{r}31.0 \\
0\end{array}$ & $\begin{array}{r}45.0 \\
0\end{array}$ & 50.00 & $\begin{array}{r}44.0 \\
0\end{array}$ & $\begin{array}{r}44.0 \\
0\end{array}$ & $\begin{array}{r}45.0 \\
0\end{array}$ & $\begin{array}{r}49.0 \\
0\end{array}$ & $\begin{array}{r}51.0 \\
0\end{array}$ & $\begin{array}{r}45.0 \\
0\end{array}$ & $\begin{array}{r}43.0 \\
0\end{array}$ & $\begin{array}{r}45.0 \\
0\end{array}$ & $\begin{array}{r}47.0 \\
0\end{array}$ & $\begin{array}{r}36.0 \\
0\end{array}$ & $\begin{array}{r}28.0 \\
0\end{array}$ & $\begin{array}{r}39.0 \\
0\end{array}$ & $\begin{array}{r}66.0 \\
0\end{array}$ \\
\hline$Y$ & 47.00 & $\begin{array}{r}42.0 \\
0\end{array}$ & $\begin{array}{r}49.0 \\
0\end{array}$ & $\begin{array}{r}45.0 \\
0\end{array}$ & 43.00 & $\begin{array}{r}45.0 \\
0\end{array}$ & $\begin{array}{r}44.0 \\
0\end{array}$ & $\begin{array}{r}45.0 \\
0\end{array}$ & $\begin{array}{r}44.0 \\
0\end{array}$ & $\begin{array}{r}44.0 \\
0\end{array}$ & $\begin{array}{r}45.0 \\
0\end{array}$ & $\begin{array}{r}45.0 \\
0\end{array}$ & $\begin{array}{r}43.0 \\
0\end{array}$ & $\begin{array}{r}46.0 \\
0\end{array}$ & $\begin{array}{r}43.0 \\
0\end{array}$ & $\begin{array}{r}44.0 \\
0\end{array}$ & $\begin{array}{r}42.0 \\
0\end{array}$ & $\begin{array}{r}36.0 \\
0\end{array}$ \\
\hline $\mathrm{Zn}$ & 128.00 & $\begin{array}{r}119 . \\
00\end{array}$ & $\begin{array}{r}195 . \\
00\end{array}$ & $\begin{array}{r}104 . \\
00\end{array}$ & $\begin{array}{r}103.0 \\
0\end{array}$ & $\begin{array}{r}104 . \\
00\end{array}$ & $\begin{array}{r}105 . \\
00\end{array}$ & $\begin{array}{r}108 . \\
00\end{array}$ & $\begin{array}{r}105 . \\
00\end{array}$ & $\begin{array}{r}103 . \\
00\end{array}$ & $\begin{array}{r}111 . \\
00\end{array}$ & $\begin{array}{r}107 . \\
00\end{array}$ & $\begin{array}{r}109 . \\
00\end{array}$ & $\begin{array}{r}110 . \\
00\end{array}$ & $\begin{array}{r}94.0 \\
0\end{array}$ & $\begin{array}{r}86.0 \\
0\end{array}$ & $\begin{array}{r}109 . \\
00\end{array}$ & $\begin{array}{r}83.0 \\
0\end{array}$ \\
\hline $\mathrm{Zr}$ & 850.00 & $\begin{array}{r}880 . \\
00\end{array}$ & $\begin{array}{r}1100 \\
.00\end{array}$ & $\begin{array}{r}767 . \\
00\end{array}$ & $\begin{array}{r}763.0 \\
0\end{array}$ & $\begin{array}{r}760 . \\
00\end{array}$ & $\begin{array}{r}738 . \\
00\end{array}$ & $\begin{array}{r}747 . \\
00\end{array}$ & $\begin{array}{r}748 . \\
00\end{array}$ & $\begin{array}{r}766 . \\
00\end{array}$ & $\begin{array}{r}757 . \\
00\end{array}$ & $\begin{array}{r}757 . \\
00\end{array}$ & $\begin{array}{r}791 . \\
00\end{array}$ & $\begin{array}{r}814 . \\
00\end{array}$ & $\begin{array}{r}835 . \\
00\end{array}$ & $\begin{array}{r}661 . \\
00\end{array}$ & $\begin{array}{r}623 . \\
00\end{array}$ & $\begin{array}{r}598 . \\
00\end{array}$ \\
\hline La & 134.57 & $\begin{array}{r}142 . \\
57\end{array}$ & $\begin{array}{r}136 . \\
05\end{array}$ & $\begin{array}{r}118 . \\
12\end{array}$ & 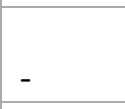 & $\begin{array}{r}127 . \\
49\end{array}$ & $\begin{array}{r}127 . \\
41\end{array}$ & $\begin{array}{r}123 . \\
18\end{array}$ & $\begin{array}{r}129 . \\
19\end{array}$ & $\begin{array}{r}127 . \\
97\end{array}$ & $\begin{array}{r}137 . \\
25\end{array}$ & $\begin{array}{r}125 . \\
83\end{array}$ & $\begin{array}{r}137 . \\
65\end{array}$ & $\begin{array}{r}134 . \\
16\end{array}$ & $\begin{array}{r}137 . \\
29\end{array}$ & $\begin{array}{r}133 . \\
07\end{array}$ & $\begin{array}{r}127 . \\
39\end{array}$ & $\begin{array}{r}121 . \\
53\end{array}$ \\
\hline $\mathrm{Ce}$ & 225.77 & $\begin{array}{r}206 . \\
71 \\
\end{array}$ & $\begin{array}{r}216 . \\
81\end{array}$ & $\begin{array}{r}236 . \\
32 \\
\end{array}$ & 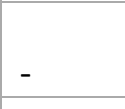 & $\begin{array}{r}241 . \\
78\end{array}$ & $\begin{array}{r}242 . \\
60 \\
\end{array}$ & $\begin{array}{r}235 . \\
55\end{array}$ & $\begin{array}{r}242 . \\
39 \\
\end{array}$ & $\begin{array}{r}245 . \\
81\end{array}$ & $\begin{array}{r}256 . \\
49\end{array}$ & $\begin{array}{r}243 . \\
79 \\
\end{array}$ & $\begin{array}{r}259 . \\
45\end{array}$ & $\begin{array}{r}260 . \\
91\end{array}$ & $\begin{array}{r}252 . \\
29 \\
\end{array}$ & $\begin{array}{r}248 . \\
29\end{array}$ & $\begin{array}{r}244 . \\
49\end{array}$ & $\begin{array}{r}211 . \\
39\end{array}$ \\
\hline $\operatorname{Pr}$ & 22.15 & $\begin{array}{r}23.4 \\
8\end{array}$ & $\begin{array}{r}23.2 \\
2\end{array}$ & $\begin{array}{r}24.0 \\
9\end{array}$ & - & $\begin{array}{r}27.0 \\
2\end{array}$ & $\begin{array}{r}26.2 \\
8\end{array}$ & $\begin{array}{r}25.5 \\
3\end{array}$ & $\begin{array}{r}26.6 \\
8\end{array}$ & $\begin{array}{r}26.4 \\
0\end{array}$ & $\begin{array}{r}28.0 \\
2\end{array}$ & $\begin{array}{r}26.2 \\
2\end{array}$ & $\begin{array}{r}27.6 \\
1\end{array}$ & $\begin{array}{r}26.7 \\
7\end{array}$ & $\begin{array}{r}25.3 \\
3\end{array}$ & $\begin{array}{r}25.7 \\
5\end{array}$ & $\begin{array}{r}25.9 \\
1\end{array}$ & $\begin{array}{r}21.5 \\
8\end{array}$ \\
\hline $\mathrm{Nd}$ & 65.20 & $\begin{array}{r}65.1 \\
3\end{array}$ & $\begin{array}{r}67.6 \\
8\end{array}$ & $\begin{array}{r}79.5 \\
4\end{array}$ & $\begin{array}{ll}- \\
-\end{array}$ & $\begin{array}{r}85.5 \\
5\end{array}$ & $\begin{array}{r}85.3 \\
0\end{array}$ & $\begin{array}{r}79.3 \\
8\end{array}$ & $\begin{array}{r}83.1 \\
3\end{array}$ & $\begin{array}{r}81.4 \\
8\end{array}$ & $\begin{array}{r}88.9 \\
2\end{array}$ & $\begin{array}{r}81.6 \\
2\end{array}$ & $\begin{array}{r}81.3 \\
5\end{array}$ & $\begin{array}{r}83.2 \\
5\end{array}$ & $\begin{array}{r}75.8 \\
4\end{array}$ & $\begin{array}{r}76.7 \\
2\end{array}$ & $\begin{array}{r}79.9 \\
2\end{array}$ & $\begin{array}{r}67.4 \\
8\end{array}$ \\
\hline
\end{tabular}




\section{Journal Pre-proof}

\begin{tabular}{|c|c|c|c|c|c|c|c|c|c|c|c|c|c|c|c|c|c|c|}
\hline & 9.61 & 943 & 986 & $\begin{array}{r}12.0 \\
5\end{array}$ & - & 13.1 & 13.1 & 12.2 & $\begin{array}{r}12.0 \\
?\end{array}$ & $\begin{array}{r}12.3 \\
4\end{array}$ & $\begin{array}{r}12.9 \\
7\end{array}$ & $\begin{array}{r}12.6 \\
8\end{array}$ & 12.5 & 12.9 & 11.9 & $\begin{array}{r}11.9 \\
8\end{array}$ & $\begin{array}{r}11.4 \\
3\end{array}$ & $\begin{array}{r}10.0 \\
3\end{array}$ \\
\hline $\mathrm{Eu}$ & 2.02 & 2.02 & 2.12 & 2.98 & - & 3.05 & 3.03 & 3.15 & 3.09 & 2.80 & 3.13 & 3.09 & 2.86 & 2.93 & 2.91 & 2.86 & 2.97 & 3.08 \\
\hline & & 10.7 & 11.3 & 11.7 & & 12.8 & 13.0 & 12.6 & 12.1 & 12.2 & 13.2 & 12.2 & 12.6 & 12.3 & 11.3 & 11.6 & 11.9 & 10.2 \\
\hline $\mathrm{Gd}$ & 10.62 & 5 & 1 & 0 & - & 1 & 4 & 4 & 5 & 3 & 1 & 4 & 4 & 6 & 4 & 9 & 1 & 2 \\
\hline $\mathrm{Tb}$ & 1.28 & 1.16 & 1.38 & 1.21 & - & 1.40 & 1.42 & 1.35 & 1.38 & 1.36 & 1.46 & 1.27 & 1.30 & 1.35 & 1.26 & 1.27 & 1.34 & 1.22 \\
\hline Dy & 6.91 & 7.14 & 7.35 & 7.46 & - & 8.21 & 8.00 & 7.79 & 7.20 & 7.57 & 7.78 & 7.40 & 7.42 & 8.05 & 7.04 & 7.50 & 7.28 & 6.30 \\
\hline $\mathrm{Ho}$ & 1.29 & 1.21 & 1.40 & 1.24 & - & 1.31 & 1.29 & 1.22 & 1.14 & 1.24 & 1.29 & 1.28 & 1.33 & 1.27 & 1.23 & 1.37 & 1.27 & 1.20 \\
\hline $\mathrm{Er}$ & 4.04 & 3.81 & 4.30 & 3.76 & - & 3.84 & 3.50 & 3.52 & 3.80 & 3.86 & 4.06 & 3.46 & 3.52 & 4.08 & 3.44 & 3.95 & 3.52 & 3.37 \\
\hline $\mathrm{Tm}$ & 0.59 & 0.51 & 0.59 & 0.49 & - & 0.47 & 0.42 & 0.44 & 0.42 & 0.40 & 0.48 & 0.37 & 0.41 & 0.48 & 0.42 & 0.42 & 0.43 & 0.41 \\
\hline $\mathrm{Yb}$ & 3.89 & 3.74 & 4.13 & 2.88 & - & 3.29 & 3.01 & 3.20 & 3.16 & 2.89 & 3.40 & 2.98 & 3.01 & 3.43 & 2.96 & 2.90 & 2.95 & 2.91 \\
\hline Lu & 0.55 & 0.56 & 0.59 & 0.38 & - & 0.44 & 0.44 & 0.46 & 0.41 & 0.41 & 0.42 & 0.45 & 0.50 & 0.46 & 0.37 & 0.39 & 0.34 & 0.41 \\
\hline $\begin{array}{l}\text { calculated } \\
\mathrm{T}(\underline{\circ} \mathrm{C})\end{array}$ & 37 & 859 & 847 & 897 & 887 & 890 & 894 & 903 & 889 & 885 & 890 & 898 & 892 & 877 & 888 & 892 & 876 & $\begin{array}{c}1000 \\
*\end{array}$ \\
\hline $\begin{array}{l}\text { Z: stratigraph- } \\
\text { ic height }(\mathrm{m})\end{array}$ & 0.00 & 0.00 & 3.50 & 7.00 & 9.70 & $\begin{array}{r}12.4 \\
0\end{array}$ & $\begin{array}{r}15.1 \\
0\end{array}$ & $\begin{array}{r}17.8 \\
0\end{array}$ & $\begin{array}{r}20.5 \\
0\end{array}$ & $\begin{array}{r}23.2 \\
0\end{array}$ & $\begin{array}{r}25.9 \\
0\end{array}$ & $\begin{array}{r}28.6 \\
0\end{array}$ & $\begin{array}{r}28.6 \\
0\end{array}$ & $\begin{array}{r}28.6 \\
0\end{array}$ & $\begin{array}{r}31.3 \\
0\end{array}$ & $\begin{array}{r}34.0 \\
0\end{array}$ & $\begin{array}{r}34.0 \\
0\end{array}$ & $\begin{array}{r}36.7 \\
0\end{array}$ \\
\hline
\end{tabular}

calculated $\mathrm{T}(\stackrel{\mathrm{O}}{\mathrm{C}})$ : T estimated based on equation 1 on the main text

$<$ LOD:elements concentration below the detection limit

nd: not determined

sd: standard deviation calculated on 3 analysis basis

*: temperature estimated from literature: see text for details 
Declaration of competing interests

$X$ The authors declare that they have no known competing financial interests or personal relationships that could have appeared to influence the work reported in this paper.

$\square$ The authors declare the following financial interests/personal relationships which may be considered as potential competing interests: 


\section{Credit Author Statement}

Joan Marti: Conceptualisation, investigation, writing original draft and revision

Silvia Zafrilla: Data curation, formal analysis, methodology, investigation, writing original draft Joan Andujar: Data curation, formal analysis, methodology, investigation, writing original draft María Jiménez-Mejías: Data curation, formal analysis

Bruno Scaillet: Data curation, formal analysis, methodology, investigation, writing original draft Dario Pedrazzi: Data curation, formal analysis, methodology, investigation, writing original draft Domenico Doronzo: Data curation, formal analysis, methodology, investigation, writing original draft Staphane Scaillet: Data curation, formal analysis 


\section{Highlights}

Pre-eruptive processes occurring in magma chambers are recorded in the products of these eruptions

Characterisation in terms of magma composition and physics offers the clues to understand past eruptions and predict future ones

El Palomar Member (712 $\pm 41 \mathrm{ka})$, in Las Cañadas caldera, Teide, Canary Islands offers a snap shot of the internal structure of the magma chamber prior to eruption.

Tenerife phonolitic eruptions have the potential to prepare and develop in a short period of time of several weeks to few months . 


\section{Appendix: dataset and regression strategy}

The dataset used here to derive equation 1 that back-calculates the $\mathrm{T}$ of phonolitic melts from Tenerife, and in particular, that of El Palomar, is that obtained through phase equilibrium experiments performed by Andújar et al. (2008, 2010, 2013) and Andújar and Scaillet (2012) on different Tenerife phonolitic magmas. The experimental database considered encompasses a range of conditions varying between $50-250 \mathrm{MPa}, 700-925^{\circ} \mathrm{C}$, and $\mathrm{H}_{2} \mathrm{O}$ in melt varying from 9.5 to $1.5 \mathrm{wt} \%$ and liquid compositions in the range 59-62 wt $\% \mathrm{SiO}_{2}, 14-16 \mathrm{wt} \% \mathrm{Na}_{2} \mathrm{O}+\mathrm{K}_{2} \mathrm{O}, 0.1-0.5 \mathrm{MgO}, 0.2-1.2 \mathrm{wt} \%$ $\mathrm{CaO}, 0.2-0.7 \mathrm{wt} \% \mathrm{FeO}^{*}$ and $0.2-0.7 \mathrm{wt} \% \mathrm{TiO}_{2}$ (Table 1 appendix). Preliminary least square analyses were conducted on experimental data from 103 runs, using the whole major oxide dataset information. However, in this case the calculations reported very low degrees of correlation. Subsequently, regression analysis was performed considering a limited number of elements that best track the liquid line of descent in these magmas and those that provide reasonable matching between $\mathrm{XRF}$ portable and laboratory data (hence $\mathrm{CaO}, \mathrm{TiO}, \mathrm{FeO} *$ ). This procedure allowed us to retrieve comparable temperatures using either laboratory or field in-situ data and ensured the generation of regression parameters with high degrees of correlation, as evidenced by the relation between measured $\mathrm{T}$ and calculated $\mathrm{T}\left(\mathrm{R}^{2}=0.95\right.$; Fig. 1 of this appendix).

The derived equation for $\mathrm{T}$ predictions:

Eq. $1: \mathrm{T}^{\circ} \mathrm{C}=131.268 * \mathrm{CaO}(\mathrm{wt} \%)+200.012 * \mathrm{TiO}_{2}(\mathrm{wt} \%)-31.272 * \mathrm{FeO} *(\mathrm{wt} \%)+725.611$ This equation back-calculates the temperature of the phonolitic liquids used for calibration to within $\pm 16^{\circ} \mathrm{C}$, and is valid for the $700-925^{\circ} \mathrm{C}$ temperature interval (Table 1 appendix).

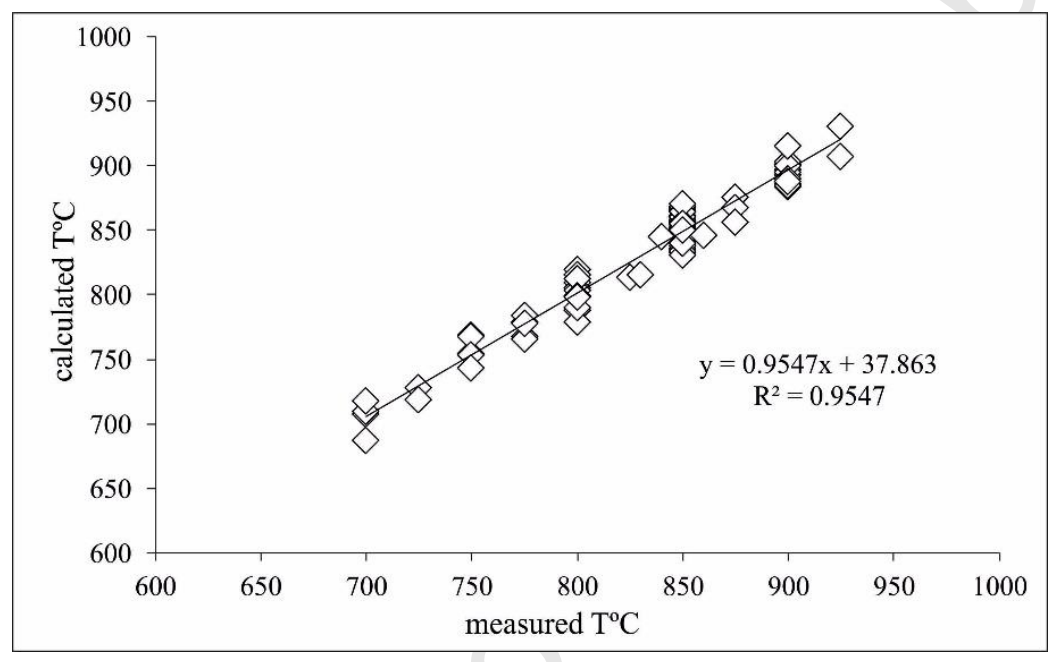

Figure 1 appendix: measured versus calculated T using Equation 1.

Table 1 appendix: dataset used for least squares regression calculations

reference

Andujar et al. (2013)

$\begin{array}{cccc}\text { run label } & \mathbf{T i O}_{\mathbf{2}} & \mathbf{C a O} & \mathbf{F e O} \\ \text { RB2 } & 0.52 & 0.87 & 2.38 \\ \text { RB3 } & 0.55 & 0.85 & 2.50 \\ \text { RB4 } & 0.54 & 0.76 & 2.51 \\ \text { RB26 } & 0.53 & 0.83 & 2.54 \\ \text { RB27 } & 0.48 & 0.85 & 2.44 \\ \text { RB28 } & 0.48 & 0.72 & 2.45 \\ \text { RB29 } & 0.57 & 0.61 & 2.70 \\ \text { RB14 } & 0.41 & 1.00 & 2.22 \\ \text { RB31 } & 0.51 & 0.71 & 2.79 \\ \text { RB32 } & 0.58 & 0.71 & 2.82\end{array}$

measured $\mathbf{T}^{\mathbf{0}} \mathbf{C}$
850
850
850
850
850
850
850
850
850
850

calculated

$\mathrm{T}^{\mathbf{0}} \mathrm{C}$ 


\begin{tabular}{|c|c|c|c|c|c|c|}
\hline$"$ & RB34 & 0.65 & 0.71 & 3.30 & 850 & 845 \\
\hline$"$ & RB49 & 0.26 & 0.75 & 2.11 & 800 & 810 \\
\hline$"$ & RB50 & 0.24 & 0.66 & 2.28 & 800 & 789 \\
\hline$"$ & RB61 & 0.43 & 0.59 & 2.67 & 800 & 805 \\
\hline$"$ & RB85 & 0.72 & 0.90 & 3.03 & 900 & 894 \\
\hline$"$ & RB86 & 0.70 & 0.90 & 2.81 & 900 & 897 \\
\hline$"$ & RB87 & 0.64 & 0.99 & 2.66 & 900 & 900 \\
\hline$"$ & RB88 & 0.65 & 0.94 & 2.65 & 900 & 896 \\
\hline$"$ & RB89 & 0.65 & 0.92 & 2.38 & 900 & 901 \\
\hline$"$ & RB 91 & 0.71 & 0.97 & 2.91 & 900 & 903 \\
\hline$"$ & RB 93 & 0.65 & 0.89 & 2.35 & 900 & 900 \\
\hline$"$ & RB 94 & 0.58 & 0.99 & 2.84 & 900 & 884 \\
\hline$"$ & RB 95 & 0.60 & 0.95 & 2.69 & 900 & 885 \\
\hline$"$ & RB 96 & 0.60 & 0.95 & 2.71 & 900 & 886 \\
\hline$"$ & RB 97 & 0.70 & 0.83 & 2.88 & 900 & 885 \\
\hline$"$ & RB 98 & 0.72 & 0.86 & 2.93 & 900 & 890 \\
\hline$"$ & RB 99 & 0.69 & 0.83 & 2.80 & 900 & 885 \\
\hline$"$ & RB 101 & 0.70 & 0.78 & 2.60 & 900 & 888 \\
\hline$"$ & RB 73 & 0.48 & 0.92 & 2.61 & 850 & 862 \\
\hline$"$ & RB 75 & 0.50 & 0.88 & 2.62 & 850 & 859 \\
\hline Andújar et al. (2010) & LN7 & 0.51 & 0.87 & 2.09 & 875 & 876 \\
\hline$"$ & LN11 & 0.46 & 0.56 & 1.77 & 850 & 836 \\
\hline " & LN12 & 0.54 & 0.60 & 2.28 & 850 & 841 \\
\hline$"$ & LN13 & 0.46 & 0.82 & 1.88 & 875 & 867 \\
\hline " & LN18 & 0.69 & 0.89 & 2.07 & 900 & 915 \\
\hline " & LN15 & 0.57 & 1.09 & 2.16 & 900 & 915 \\
\hline " & LN20 & 0.63 & 1.21 & 2.56 & 925 & 931 \\
\hline$"$ & $\mathrm{LN} 22$ & 0.20 & 0.39 & 1.55 & 775 & 768 \\
\hline$"$ & LN19 & 0.26 & 0.35 & 1.85 & 775 & 766 \\
\hline$"$ & LN1 & 0.16 & 0.57 & 1.68 & 800 & 780 \\
\hline " & LN26 & 0.63 & 1.06 & 2.69 & 925 & 908 \\
\hline $\begin{array}{l}\text { Andújar and Scaillet } \\
\qquad(2012)\end{array}$ & MB7 & 0.68 & 0.79 & 3.13 & 850 & 867 \\
\hline$"$ & MB8 & 0.68 & 0.74 & 3.01 & 850 & 865 \\
\hline$"$ & MB9 & 0.68 & 0.76 & 3.18 & 850 & 861 \\
\hline$"$ & MB10 & 0.64 & 0.73 & 3.06 & 850 & 855 \\
\hline$"$ & MB11 & 0.63 & 0.64 & 3.11 & 850 & 838 \\
\hline$"$ & MB19 & 0.66 & 0.74 & 3.30 & 850 & 852 \\
\hline$"$ & MB20 & 0.69 & 0.73 & 2.99 & 850 & 866 \\
\hline$"$ & MB21 & 0.63 & 0.66 & 2.97 & 850 & 844 \\
\hline$"$ & MB22 & 0.67 & 0.60 & 3.10 & 850 & 842 \\
\hline$"$ & MB38 & 0.62 & 0.67 & 3.12 & 850 & 841 \\
\hline$"$ & MB39 & 0.64 & 0.77 & 2.74 & 850 & 868 \\
\hline$"$ & MB40 & 0.63 & 0.71 & 3.06 & 850 & 848 \\
\hline$"$ & MB43 & 0.66 & 0.61 & 3.09 & 850 & 841 \\
\hline$"$ & MB44 & 0.62 & 0.78 & 3.18 & 850 & 852 \\
\hline
\end{tabular}




\begin{tabular}{|c|c|c|c|c|c|c|}
\hline$"$ & MB48 & 0.63 & 0.69 & 2.77 & 850 & 856 \\
\hline " & MB55 & 0.46 & 0.61 & 2.46 & 800 & 820 \\
\hline$"$ & MB58 & 0.47 & 0.54 & 2.36 & 800 & 815 \\
\hline " & MB102 & 0.60 & 0.73 & 2.98 & 850 & 847 \\
\hline " & MB103 & 0.58 & 0.77 & 2.93 & 850 & 850 \\
\hline$"$ & MB104 & 0.60 & 0.65 & 3.01 & 850 & 838 \\
\hline$"$ & MB105 & 0.67 & 0.63 & 2.92 & 850 & 851 \\
\hline " & MB106 & 0.70 & 0.62 & 2.82 & 850 & 860 \\
\hline " & MB108 & 0.62 & 0.74 & 2.91 & 850 & 855 \\
\hline " & MB109 & 0.60 & 0.70 & 2.93 & 850 & 846 \\
\hline$"$ & MB110 & 0.60 & 0.74 & 2.93 & 850 & 852 \\
\hline$"$ & MB111 & 0.73 & 0.66 & 2.96 & 850 & 865 \\
\hline " & MB112 & 0.66 & 0.65 & 3.02 & 850 & 848 \\
\hline " & MB113 & 0.59 & 0.68 & 3.11 & 850 & 834 \\
\hline$"$ & MB114 & 0.71 & 0.63 & 3.05 & 850 & 856 \\
\hline$"$ & MB115 & 0.72 & 0.59 & 3.01 & 850 & 853 \\
\hline$"$ & MB117 & 0.71 & 0.65 & 3.24 & 850 & 851 \\
\hline$"$ & MB118 & 0.74 & 0.67 & 2.89 & 850 & 870 \\
\hline$"$ & MB119 & 0.70 & 0.70 & 3.41 & 850 & 852 \\
\hline Andújar et al. (2008) & 3 & 0.66 & 0.70 & 3.00 & 850 & 856 \\
\hline$"$ & 5 & 0.38 & 0.31 & 2.80 & 750 & 755 \\
\hline$"$ & 8 & 0.70 & 0.67 & 3.10 & 875 & 857 \\
\hline " & 11 & 0.60 & 0.53 & 2.70 & 850 & 831 \\
\hline " & 15 & 0.15 & 0.17 & 2.90 & 700 & 687 \\
\hline " & 18 & 0.75 & 0.50 & 3.00 & 850 & 847 \\
\hline$"$ & 20 & 0.38 & 0.40 & 2.40 & 775 & 779 \\
\hline " & 21 & 0.25 & 0.30 & 2.30 & 750 & 743 \\
\hline$"$ & 22 & 0.17 & 0.24 & 2.00 & 725 & 729 \\
\hline " & 23 & 0.12 & 0.16 & 2.00 & 700 & 708 \\
\hline$"$ & 25 & 0.51 & 0.41 & 2.50 & 800 & 803 \\
\hline " & $26 b$ & 0.62 & 0.60 & 2.70 & 850 & 844 \\
\hline$"$ & $27 b$ & 0.40 & 0.32 & 2.50 & 750 & 769 \\
\hline " & $28 b$ & 0.70 & 0.36 & 3.20 & 800 & 813 \\
\hline " & 29 & 0.56 & 0.28 & 3.40 & 750 & 768 \\
\hline " & $30 \mathrm{~b}$ & 0.60 & 0.60 & 2.70 & 850 & 840 \\
\hline$"$ & $31 b$ & 0.28 & 0.19 & 3.10 & 700 & 710 \\
\hline " & 32 & 0.34 & 0.27 & 2.40 & 750 & 754 \\
\hline " & 33 & 0.23 & 0.16 & 2.40 & 700 & 718 \\
\hline " & 35 & 0.67 & 0.39 & 3.10 & 825 & 814 \\
\hline " & 36 & 0.47 & 0.30 & 2.40 & 775 & 784 \\
\hline " & 38 & 0.19 & 0.23 & 2.40 & 725 & 719 \\
\hline " & 42 & 0.49 & 0.32 & 2.40 & 800 & 791 \\
\hline " & 43 & 0.57 & 0.44 & 2.60 & 830 & 816 \\
\hline " & 44 & 0.63 & 0.60 & 2.70 & 860 & 846 \\
\hline " & 45 & 0.47 & 0.35 & 2.80 & 775 & 778 \\
\hline " & 46 & 0.54 & 0.36 & 2.60 & 800 & 800 \\
\hline
\end{tabular}




$\begin{array}{lllllll}" & 47 & 0.62 & 0.56 & 2.50 & 840 & 845 \\ " & 49 & 0.36 & 0.23 & 2.70 & 750 & 743 \\ & 1-x & 0.65 & 0.65 & 2.90 & 850 & 850 \\ & 2-x & 0.47 & 0.48 & 2.70 & 800 & 798\end{array}$

\section{Independent varia-} bles

$\mathrm{a}$
$\mathrm{b}$
$\mathrm{c}$

Equation 1:
131.268

200.012

$-31.272$

725.611

$\mathrm{T}^{\circ} \mathrm{C}=131.268 * \mathrm{CaO}(\mathrm{wt} \%)+200.012 * \mathrm{TiO} 2(\mathrm{wt} \%)-31.272 * \mathrm{FeO} *$ $(\mathrm{wt} \%)+725.611$ 


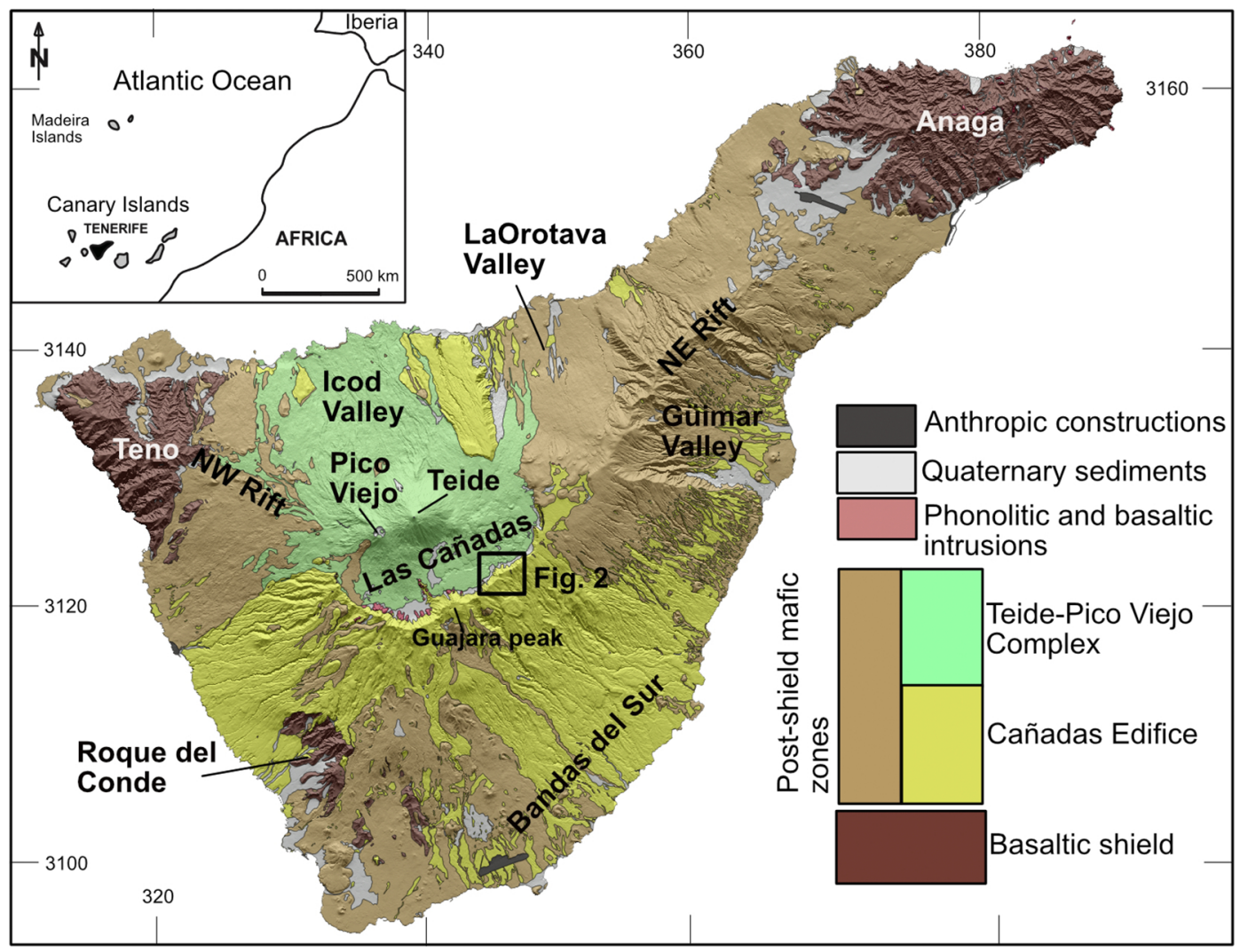

Figure 1 


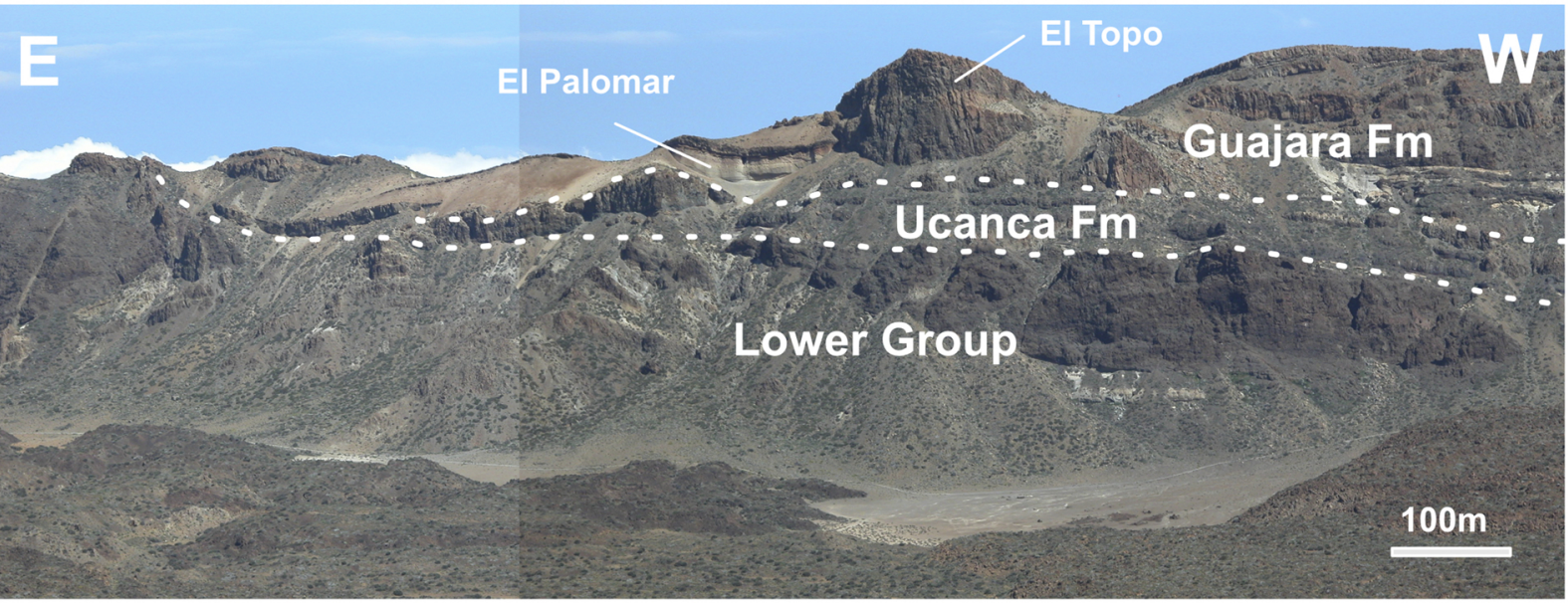

Figure 2 


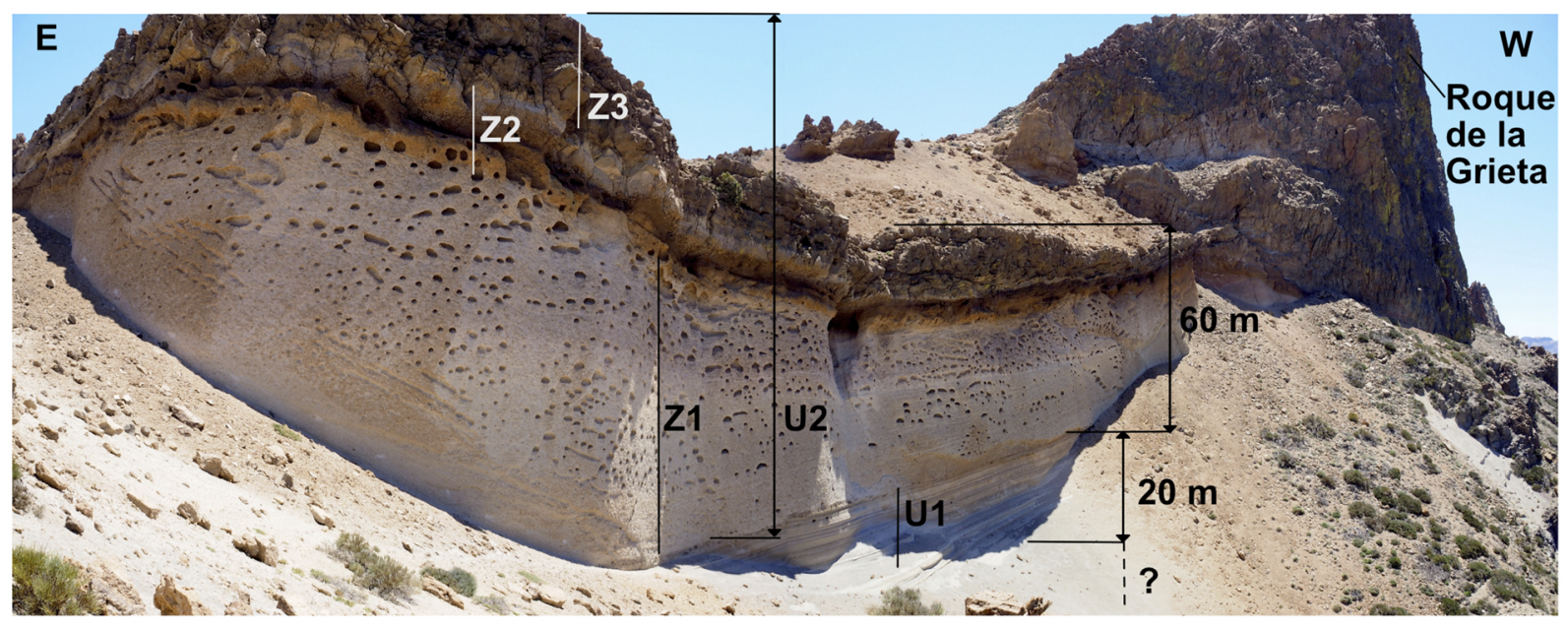

Figure 3 

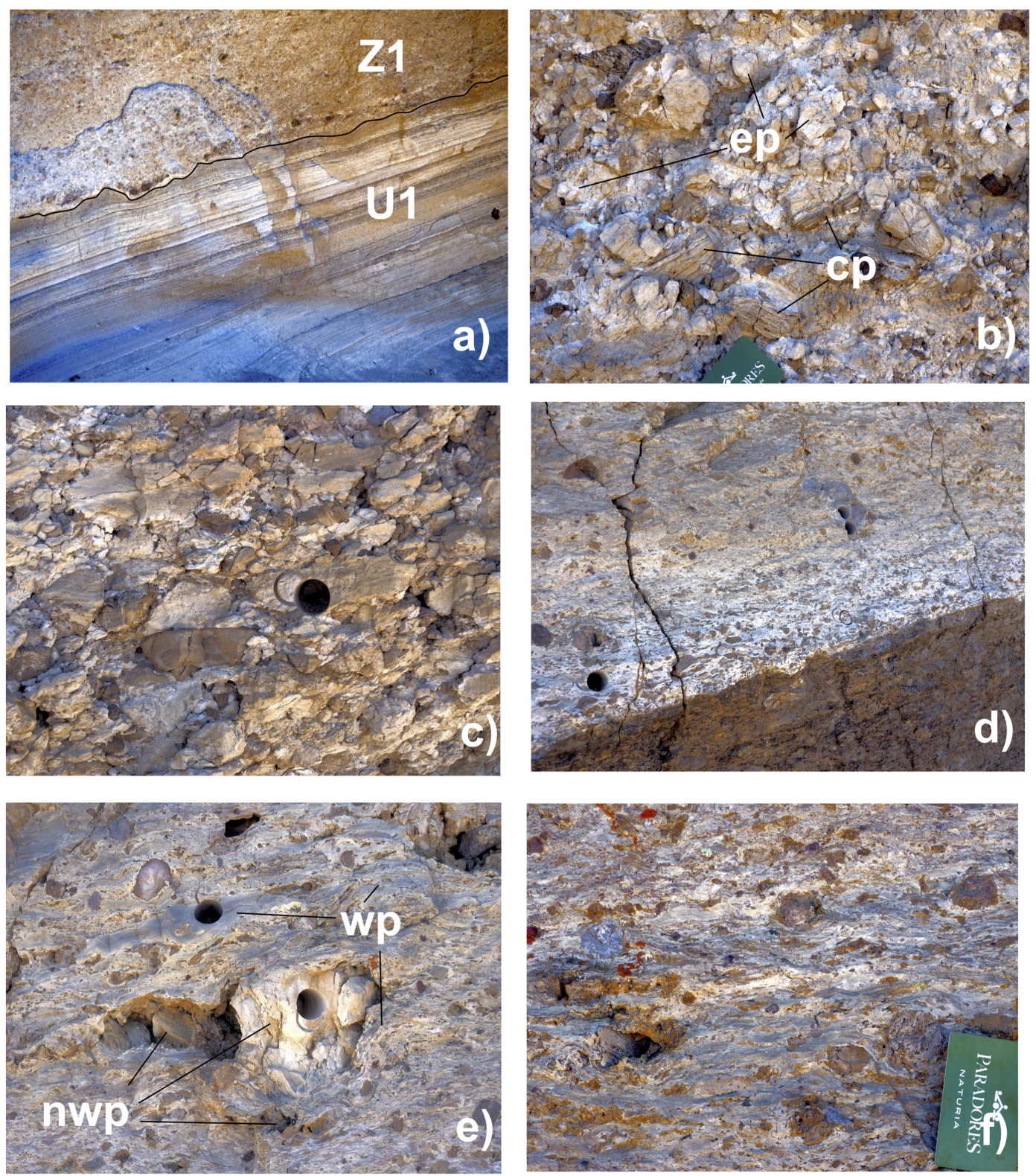

Figure 4 


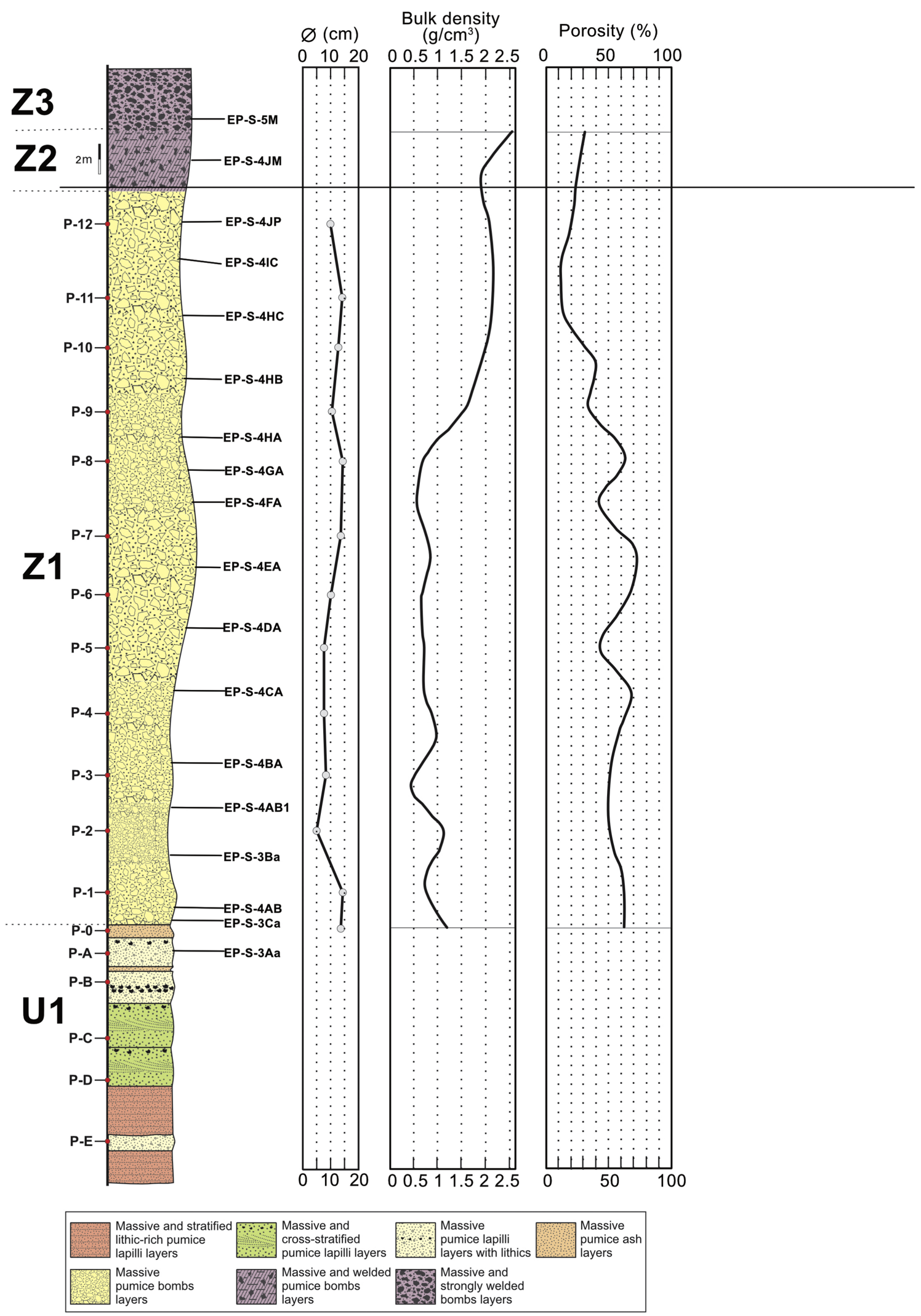




\section{Lithofacies 2}

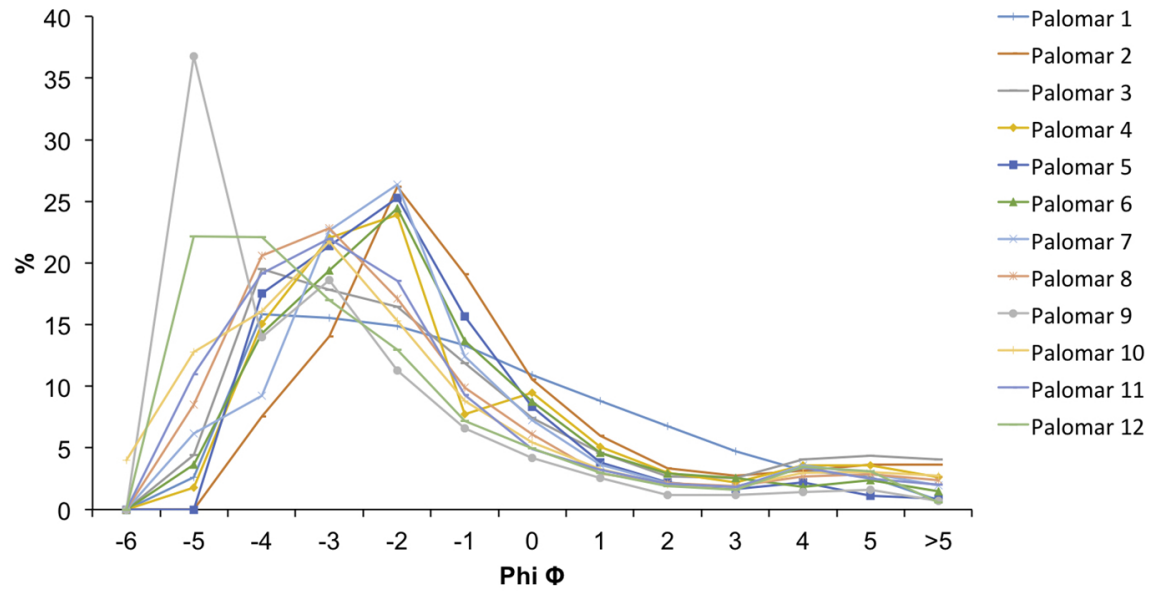

Figure 6 

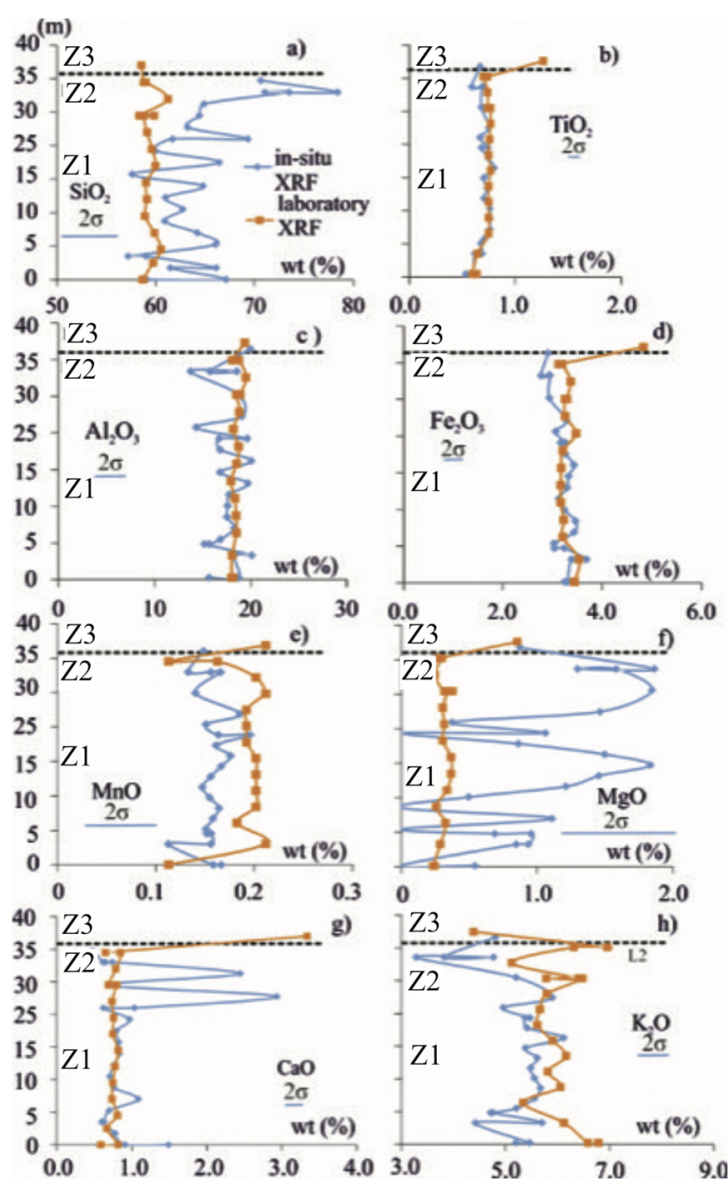

g)

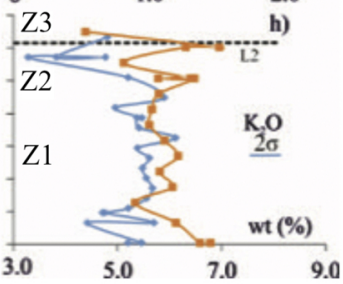

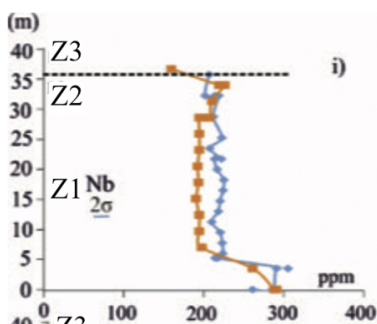
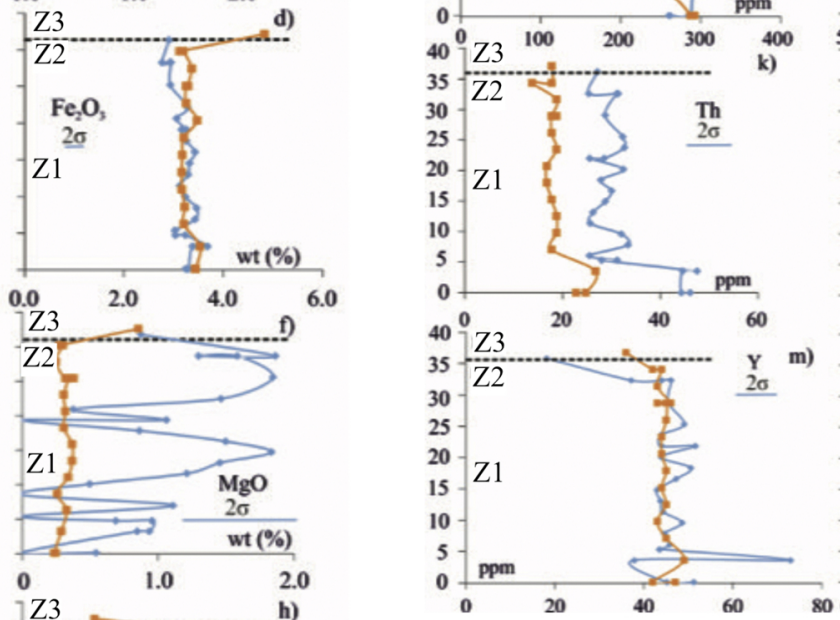

b)
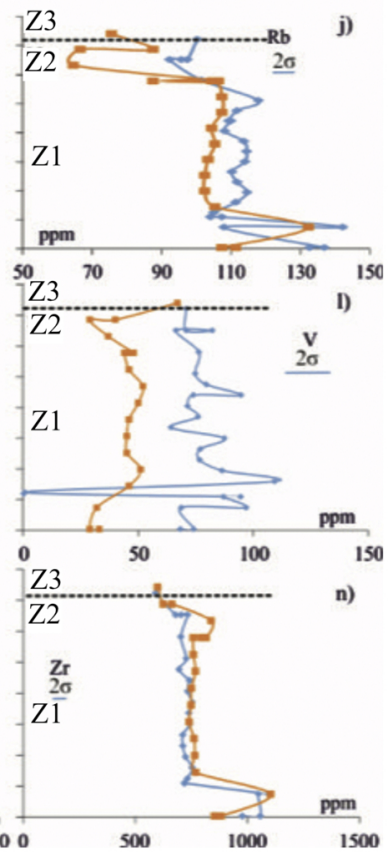

a)

Figure 7 
(m)

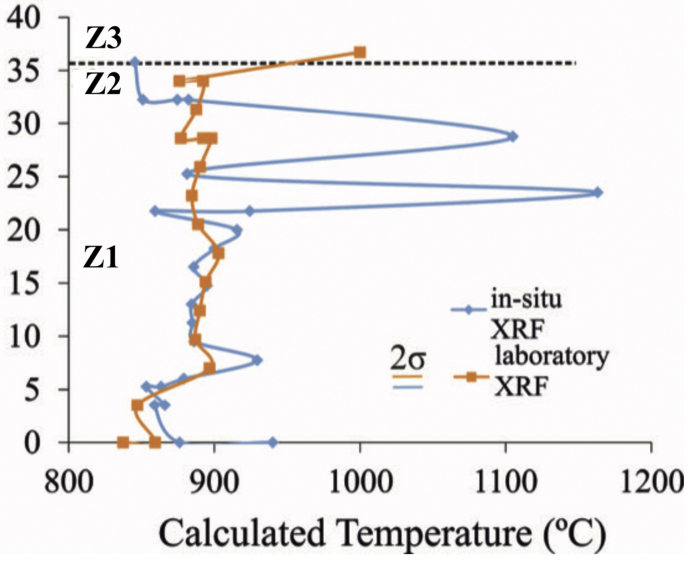

Figure 8 

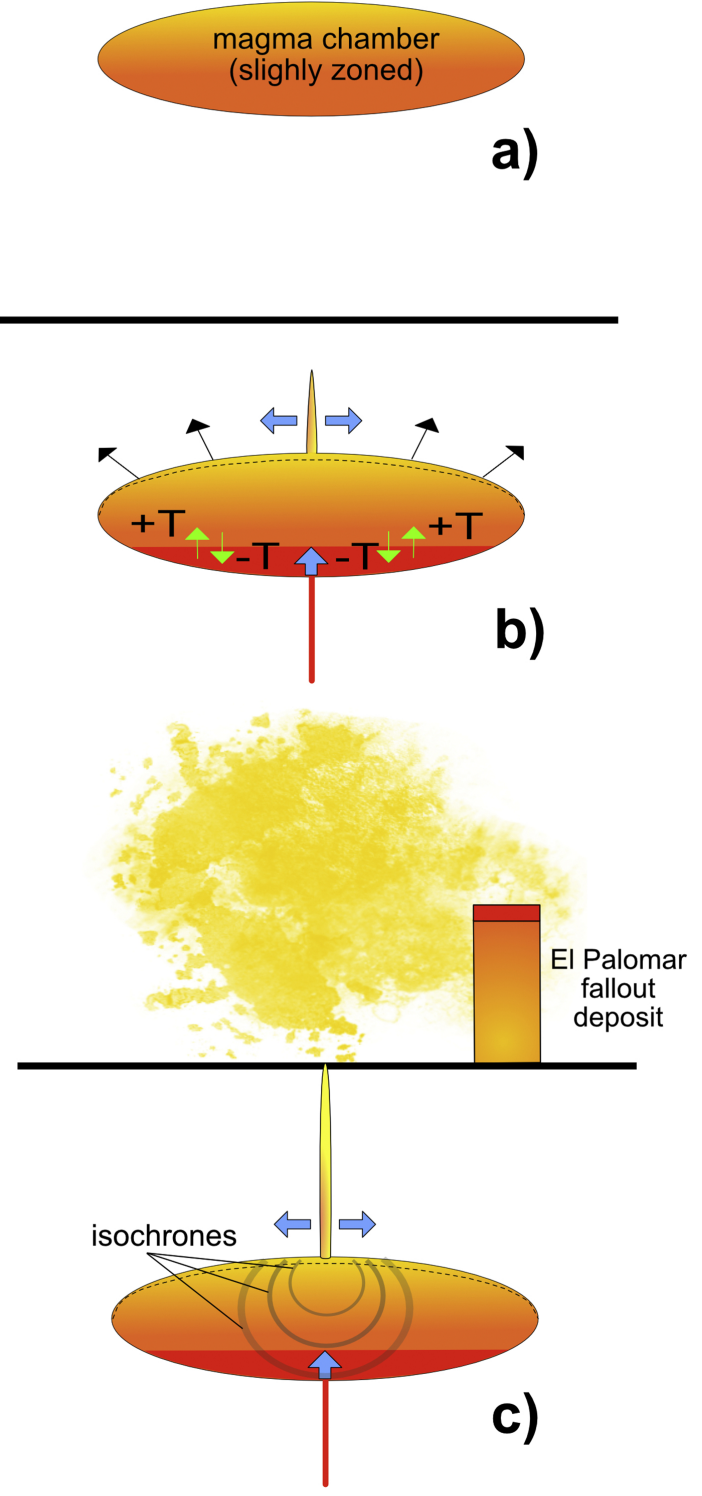

Figure 9 